\title{
ESTUDO DOS PADRÕES DE VARIABILIDADE INTRA E INTERESPECÍFICA EM MILTONIA LDL. (ORCHIDACEAE).
}

\author{
LUCIANA APARECIDA CARLINI
}

Engenheira agrônoma

Orientador: Prof. Dr. PAULO SODERO MARTINS

Dissertação apresentada à Escola Superior de Agricultura "Luiz de Queiroz", da Universidade de São Paulo, para obtenção do título de Mestre em Agronomia. Área de Concentração: Genética e Melhoramento de Plantas.

\author{
PIRACICABA \\ Estado de São Paulo - Brasil \\ Novembro - 1996
}


Dados Internacionais de Catalogaçāo na Publicação (CIP)

DIVISÃO DE BIBLIOTECA E DOCUMENTAÇÃO - Campus "Luiz de Queiroz"/USP

Carlini, Luciana Aparecida

Estudo dos padrōes de variabilidade intra e interespecifica em Milconia LDL.

(Orchidaceae) / Luciana Aparecida Carlini. - Piracicaba, 1996.

92 p. : il.

Dissertaçāo (mestrado) - Escola Superior de Agricultura Luiz de Queiroz, 1996.

Bibliografia.

1. Análise de variancia 2. Orquidea - Distribuição geográfica 3. Variabilidade genética 1. Titulo 


\section{ESTUDO DOS PADRŌES DE VARIABILIDADE INTRA E INTERESPECÍFICA EM MILTONIA LDL. (ORCHIDACEAE).}

Aprovada em: 28/01/1997

Comissão julgadora:

Prof. Dr. Paulo Sodero Martins

ESALQ/USP

Prof. Dr. Roland Vencovsky ESALQ/USP

Prof. Dr. Reinaldo Monteiro

IB/UNESP

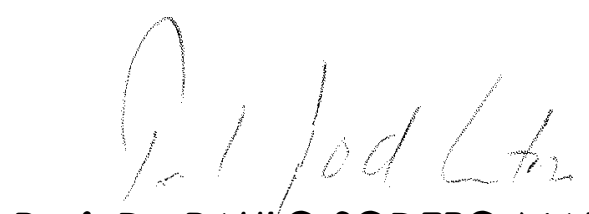

Prof. Dr. PAULO SODERO MARTINS Orientador 
"Que é o homem, que dele te lembraste? ...

Fizeste-o, no entanto, por um pouco menor do que Deus ... Deste-Ihe domínio sobre todas as obras de tua mão, ..."

SI 8: 4-6. 
A minha família dedico, especialmente a meus pais Ebear e Leila e aos meus irmãos Marcia e Adílson. 


\section{AGRADECIMENTOS}

Muitas pessoas e instituições foram importantes para a realização deste trabalho. Porém, gostaria de agradecer de forma especial:

A Deus, por ter me sustentado neste trabalho.

À Escola Superior de Agricultura "Luiz de Queiroz" pelos ensinamentos e pela minha formação acadêmica, especialmente ao Departamento de Genética.

Ao Prof. Dr. Paulo Sodero Martins, pela orientação, dedicação e amizade.

Ao Prof. Dr. Roland Vencovsky, pelos ensinamentos, incentivo e amizade.

Aos membros da comissão julgadora, pela dedicação e disponibilidade.

Ao Prof. Dr. Carlos Tadeu dos Santos Dias, membro do Departamento de Matemática e Estatística da Escola Superior de Agricultura "Luiz de Queiroz", pelo auxílio prestado nas análises estatísticas realizadas através do programa SAS.

A minha família, especialmente meus pais e irmãos e às tias Nancy e Ayrde.

Ao Augusto, pelo carinho, incentivo e companheirismo. 
Aos funcionários do Departamento de Genética, principalmente a Benedito Correa, Josué Lemos Pontes, Armando Fischer, ao Sr. Alaor de Oliveira e ao técnico do Laboratório de Genética Ecológica Ronaldo J. Rabello.

Aos funcionários da Biblioteca Central em especial 'Kátia e às funcionárias da Biblioteca do Departamento de Genética da ESALQ, Beth e Silvana.

Aos funcionários da Seção de Pós-Graduação do Departamento de Genética, principalmente à Carmen e à Léia.

Ao amigo Cássio van den Berg, pela amizade e por todo auxílio prestado durante a realização deste trabalho.

Aos alunos e amigos do Departamento de Genética e de maneira especial aos amigos do Laboratório de Genética Ecológica: Fábio, Nivaldo, Inez, Rainério, Geraldo, Roberto Cury, Beth, Gilda, Julianno, Roberto Romão, Cláudio, Elias e Ednei, pelo companheirismo.

Ao Conselho Nacional de Pesquisa (CNPq) pelo apoio financeiro. 


\section{SUMÁRIO}

LISTA DE TABELAS .................................................................................................... ix

LISTA DE FIGURAS .................................................................................................

RESUMO

SUMMARY

1. INTRODUÇÃO

2.) REVISÃO DE LITERATURA ……………..................................................................

2.1.) O gênero Miltonia Ldl. (Orchidaceae).......................................................... 3

2.1.1.) Consideraçōes gerais.................................................................... 3

2.1.2.) Considerações genéticas............................................................ 16

2.2.) Taxonomia Numérica, Fenética, Morfometria e Análise Multivariada..... 17

2.2.1.) Consideraçōes gerais.................................................................. 17

2.2.2.) Exemplos de aplicação de Taxonomia Numérica na família Orchidaceae.......................................................................... 20

2.3.) Refúgios do Pleistoceno............................................................................... 24

3.) MATERIAL E MÉTODOS ..................................................................................... 29

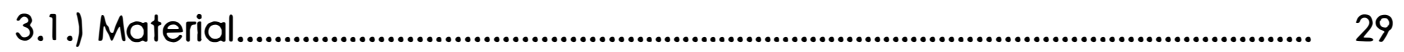

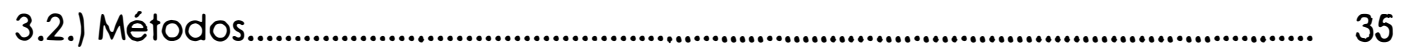

4.) RESULTADOS E DISCUSSÃO

4.1.) Entre espécies ........................................................................................ 38

4.1.1.) Entre todas as espécies analisadas............................................ 38

4.1.1.1.) Análises de variância por caráter................................. 38

4.1.1.2..) Análise de correlação entre caracteres..................... 40

4.1.1.3.) Distância generalizada de Mahalanobis (D2)............. 40

4.1.1.4.) Análise discriminantes canônica (CDA)...................... 42

4.1.1.5.) Análise de agrupamento............................................... 52 
4.1.1.6.) Análise de época e de intensidade de florescimento..................................................................... 54

4.1.2.) Entre Miltonia spectabilis e M. spectabilis var. moreliana ............... 55

4.1.2.1.) Análise discriminante canônica (CDA)............................ 56

4.1.2.2.) Análise da época e de intensidade de florescimento 58

4.2.) Dentro de espécies............................................................................................... 60

4.2.1.) Dentro de Miltonia flavescens............................................................. 60

4.2.1.1.) Análise discriminante canônica (CDA)............................ 60

4.2.1.2.) Análise de agrupamento.................................................... 65

4.2.1.3.) Análise de época e de intensidade de florescimento 67

4.2.2.) Dentro de Miltonia regnellii................................................................. 68

4.2.2.1.) Análise discriminante canônica (CDA) ............................. 68

4.2.2.2.) Análise de época e de intensidade de florescimento................................................................. 71

4.2.3.) Dentro de Miltonia spectabilis......................................................... 72

4.2.3.1.) Análise discriminante canônica (CDA)............................ 72

4.2.3.2.) Análise de agrupamento................................................... 75

4.2.3.3. Análise de época e de intensidade de florescimento.. 76

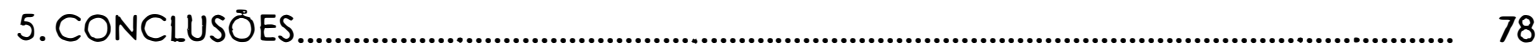

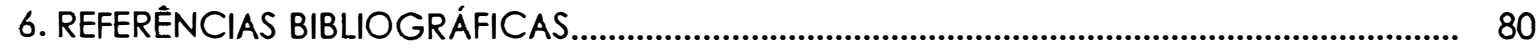

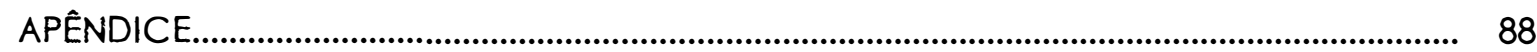




\section{LISTA DE TABELAS}

TABELA 1. Híbridos intragenéricos naturais em Miltonia Ldl. (Orchidaceae), espécies parentais e estados brasileiros onde ocorrem.........................................................

TABELA 2. Híbridos intergenéricos naturais em Miltonia Ldl. (Orchidaceae), gêneros parentais e estados brasileiros onde ocorrem............................................................

TABELA 3. Espécies de Miltonia Ldl. (Orchidaceae) consideradas, suas respectivas populações e o tamanho da amostra de cada população.

TABELA 4. Lista dos 32 caracteres florais considerados em Miltonia Ldl. (Orchidaceae) e siglas correspondentes

TABELA 5. Populações utilizadas nas análises intraespecíficas em Miltonia Ldl. (Orchidaceae)

TABELA 6. Médias, desvios-padrões, coeficientes de variação, teste $F$ e probabilidades de $\mathrm{F}$ para os 32 caracteres morfológicos estudados entre espécies de Miltonia Ldl. (Orchidaceae).

TABELA 7. Distâncias generalizadas de Mahalanobis entre espécies de Miltonia Ldl. (Orchidaceae)

TABELA 8. Variáveis canônicas entre espécies de Miltonia Ldl. (Orchidaceae), seus autovalores, diferenças entre estes autovalores, proporção da variância tołal representada por cada variável canônica e proporção cumulativa da variância com o acréscimo de sucessivas de variáveis canônicas.

TABELA 9. Coeficientes canônicos totais para Miltonia spectabilis Ldl. e M. spectabilis var. moreliana Henfrey 
TABELA 10. Variáveis canônicas entre populaçōes de Miltonia flavescens Ldl., seus autovalores, diferenças entre estes autovalores, proporçāo da variância total representada por cada variável canônica e proporçāo cumulativa da variância com o acréscimo de variáveis canônicas..........

TABELA 11. Distância generalizada de Mahalanobis entre populações de Miltonia flavescens Ldl. e probabilidades de F

TABELA 12. Coeficientes canônicos totais para populações de Miltonia regnellii Reichenbach (f.)

TABELA 13. Variáveis canônicas entre populaçōes de Miltonia spectabilis Ldl., seus autovalores, diferenças entre estes autovalores, proporçāo da variância total representada por cada variável canônica e proporção cumulativa da variância com o acréscimo de variáveis canônicas..........

TABELA 14. Distâncias generalizadas de Mahalanobis entre populações de Miltonia spectabilis Ldl. e probabilidades de F 
LISTA DE FIGURAS

FIGURA 1. Representações das flores dos taxa analisados.Fonte: McQueen \&

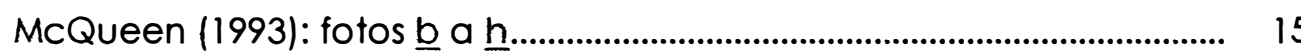

FIGURA 2. Esquema floral com indicação dos 32 caracteres florais considerados.... 31

FIGURA 3. Escores provenientes da análise discriminante canônica entre espécies de Miltonia Ldl. (Orchidaceae), considerando Can1 e Can2..........................

FIGURA 4. Contribuição das variáveis originais para os eixos canônicos 1 e 2 entre espécies de Miltonia Ldl. (Orchidaceae), utilizando coeficientes estandardizados.

FIGURA 5. Escores provenientes da análise discriminante canônica entre espécies de Miltonia Ldl. (Orchidaceae), considerando Can3 e Can4.........................

FIGURA 6. Contribuição das variáveis originais para os eixos canônicos 3 e 4 entre espécies de Miltonia Ldl. (Orchidaceae), utilizando coeficientes estandardizados.

FIGURA 7. Escores provenientes da análise discriminante canônica entre espécies de Miltonia Ldl. (Orchidaceae), considerando Can5 e Can6.

FIGURA 8. Contribuição das variáveis originais para os eixos canônicos 5 e 6 entre espécies de Miltonia Ldl. (Orchidaceae), utilizando coeficientes estandardizados.

FIGURA 9. Escores provenientes da análise discriminante canônica entre espécies de Miltonia Ldl. (Orchidaceae), considerando Can1 e Can7.......................... 51

FIGURA 10. Contribuição das variáveis originais para os eixos canônicos 1 e 7 entre espécies de Miltonia Ldl. (Orchidaceae), utilizando coeficientes estandardizados. 
FIGURA 11. Agrupamento, através do méłodo UPGMA, dos oiło taxa de Miltonia Ldl. (Orchidaceae) analisados, considerando os 32 caracteres florais avaliados.

FIGURA 12. Agrupamento, através do método de ligaçāo simples, de oito taxa de Miltonia Ldl. (Orchidaceae) analisados, considerando os 32 caracteres florais avaliados.

FIGURA 13. Épocas e intensidade (em porcentagem) de florescimento dos taxa avaliados em Miltonia Ldl. (Orchidaceae). ( $M$-anc = Miltonia anceps; $M$ $c l=M$. clowesii; $M \cdot c u=M$. cuneata; $M \cdot f l=M$. flavescens; $M \cdot m o=M$. spectabilis var. moreliana; $M \cdot r e=M$. regnellii; $M \cdot r u=M$. russeliana; $M \cdot s p=$ M. spectabilis.).

FIGURA 14. Escores provenientes da análise discriminante canônica entre Miltonia spectabilis Ldl. e M. spectabilis var. moreliana Henfrey, considerando Can1

FIGURA 15. Épocas e intensidade (em porcentagem) de florescimento Miltonia spectabilis Ldl. e Miltonia spectabilis var. moreliana Henfrey. (M. mo. = M. spectabilis var. moreliana; $M . s p .=$ M. spectabilis.)

FIGURA 16. Escores provenientes da análise discriminante canônica entre populaçōes de Miltonia flavescens Ldl., considerando Can1 e Can2.....

FIGURA 17. Contribuição das variáveis originais para os eixos canônicos 1 e 2 entre as populaçōes de Miltonia flavescens Ldl., utilizando coeficientes estandardizados

FIGURA 18. Escores provenientes da análise discriminante canônica entre populaçōes de Miltonia flavescens Ldl., considerando Can1 e Can3.

FIGURA 19. Contribuição das variáveis originais para os eixos canônicos 1 e 3 entre as populaçōes de Miltonia flavescens Ldl., utilizando coeficientes estandardizados.

FIGURA 20. Agrupamento, através do método UPGMA, das populaçōes de Miltonia flavescens Ldl. analisadas, considerando os 32 caracteres florais avaliados. 
FIGURA 21. Agrupamento, através do método de ligaçāo simples, das populaçōes de Miltonia flavescens Ldl. analisadas, considerando os 32 caracteres florais avaliados.

FIGURA 22. Épocas e intensidade (em porcentagem) de florescimento das populaçōes de Miltonia flavescens. Ldl. (fl1 - Paraguai, fl2 - Piracicaba - SP, fl3 - Petrópolis - RJ, fl4 - Juçari - BA)

FIGURA 23. Escores provenientes da Análise Discriminante Canônica entre as populaçōes de Miltonia regnellii Reichenbach (f.), considerando Can1.

FIGURA 24. Épocas e intensidade (em porcentagem) de florescimento das populaçōes de Miltonia regnellii. Reichenbach (f.). (rel - SP - norte do Paraná, re2 - Angra dos Reis - RJ)

FIGURA 25. Escores provenientes da análise discriminante canônica entre populações de Miltonia spectabilis Ldl., considerando Can1 e Can2......

FIGURA 26. Contribuição das variáveis originais para os eixos canônicos 1 e 2 entre as populaçōes de Miltonia spectabilis Ldl., utilizando coeficientes estandardizados.

FIGURA 27. Agrupamento, através do método UPGMA, das populaçōes de Miltonia spectabilis Ldl. analisadas, considerando os 32 caracteres florais avaliados.

FIGURA 28. Agrupamento, através do método de ligaçōes simples, das populaçōes de Miltonia spectabilis Ldl. analisadas, considerando os 32 caracteres florais avaliados.

FIGURA 29. Épocas e intensidade (em porcentagem) de florescimento das populaçōes de Miltonia spectabilis Ldl.. (spl - Toque - Toque Pequeno - SP, sp2 - Petrópolis - RJ, sp3 - Cascata - RJ) 


\title{
ESTUDO DOS PADRŌES DE VARIABILIDADE INTRA E INTERESPECÍFICA EM MILTONIA LDL. (ORCHIDACEAE).
}

\author{
Autora: Luciana Aparecida Carlini \\ Orientador: Prof. Dr. Paulo Sodero Martins
}

\section{RESUMO:}

A família Orchidaceae é uma das mais extensas dentro de Angiospermae. Encontra-se distribuída em todos os continentes, chamando a atenção pela sua complexidade e pela sua beleza. Dentro desta família, encontra-se o gênero Miltonia, restrito à América do Sul, concentrado principalmente no Brasil. Segundo Baker \& Baker (1995) o gênero possui atualmente nove espécies.

As espécies consideradas neste trabalho foram: Miltonia anceps (Ldl.), M. clowesii Ldl., M. cuneata Ldl., M. flavescens (Ldl.) Ldl., M. regnellii Reichenbach (f.), M. russeliana (Ldl.) Lindley, M. spectabilis Ldl. e M. spectabilis var. moreliana Henfrey. 
Foram feitas coletas de espécies deste gênero em diversos locais do Brasil, sendo que M. flavescens, foi coletada também no Paraguai, respeitando a abundância das plantas em cada local. Estas plantas foram trazidas para o orquidário do Departamento de Genética da Escola Superior de Agricultura "Luiz de Queiroz", onde foram mantidas, por anos, sob condições ambientais uniformes, o que garante que a variabilidade expressada por elas seja, predominantemente, de natureza genética.

Foi feito herbário floral de cada planta coletada e, de cada flor, foram tomadas medidas de comprimento e largura do labelo, das sépalas lateral e dorsal, da pétala, comprimento, largura e espessura de coluna, comprimento do pedúnculo e comprimento de ovário. As coletas, a manutenção e os herbários florais deste material foram feitos por funcionários e professores do referido departamento.

Medidas florais adicionais foram tomadas: largura das sépalas dorsal e lateral, pétala e labelo a cada $20 \%$ do comprimento de cada um destes órgãos e comprimentos a cada $25 \%$ da largura do labelo.

Com objetivo de avaliar os padrões de variabilidade intra e interespecífica foram feitas as seguintes análises: análise de variância (ANAVA) para cada caráter isoladamente; análise de correlação entre 
todos os pares de caracteres, distâncias generalizadas de Mahalanobis (D2) entre espécies e entre populações dentro de espécies, análise de discriminantes canônicas (CDA), funções discriminantes e análise de agrupamento. Foram também considerados dados biogeográficos e de florescimento.

A partir dos resultados, foi possível concluir que há concordância entre os grupos obtidos através da taxonomia numérica e da taxonomia tradicional, exceto pelo fato de que se sugere que $M$. spectabilis var. moreliana passe a ser uma espécie, como proposto por Martins (1967).

Conclui-se também que há variação clinal entre as populações de M. flavescens no sentido norte - sul. Porém, a população de Juçari - BA, localizada no extremo norte da área de distribuição considerada de $M$. flavescens, é uma raça. As populações de $M$. spectabilis também apresentam variação clinal no sentido norte - sul, sendo que a população de Cascata - RJ, localizada no extremo norte da área de distribuição considerada de M. spectabilis, deve ser considerada uma raça. Diferenças na época de florescimento entre as populações marginais dentro destas duas espécies é um fator importante de diferenciação, pois dificulta o fluxo de genes entre estas 
populações e as demais dentro da mesma espécie. As duas populações de $M$. regnellii são raças diferentes.

Observou-se, também, que as populações localizadas em áreas de refúgios do Pleistoceno tendem a se diferenciar das demais populações da mesma espécie. Além disso, espécies endêmicas localizam-se nestas áreas. 
STUDY OF THE PATTERNS OF INTRA AND INTERESPECIFIC VARIABILITY IN MILTONIA LDL. (ORCHIDACEAE).

\author{
Author: Luciana Aparecida Carlini \\ Adviser: Prof. Dr. Paulo Sodero Martins
}

\title{
SUMMARY:
}

Orchidaceae is one of the largest families of the Angiospermae. It occurs in all continents, and it outstands because of its complexity and beauty. The genus Miltonia belongs to this family, occuring only in South America and being concentrated mainly in Brazil. Baker \& Baker (1995) consider that there are nowadays nine species in this genus.

The species considered in this paper are: Miltonia anceps (Ldl.), M. clowesii Ldl., M. cuneata Ldl., M. flavescens (Ldl.) Ldl., M. regnellii Reichenbach (f.), M. russeliana (Ldl.) Lindley, M. spectabilis Ldl. e M. spectabilis var. moreliana Henfrey. 
Samples of these species were collected in several sites in Brazil by the staff of the Departament of Genetics of Escola Superior de Agricultura "Luiz de Queiroz". M. flavescens was also collected in Paraguai. These plants were brought to this department, where they were maintained for many years under uniform environmental condictions, what warrentees that the expressed variability is mainly of genetic nature.

These people have done floral herbarium for each collected plant and have taken some measurements: lip, sepal and petal lengths, column length, width and thickness, and length of ovary and pedicel. Furthermore, other measurements, which include sepals, petal and lip width on each $20 \%$ of their length and lip length at $25 \%$ of their width were taken.

The objective of this research was to evaluate intra and interspecific variability patterns. The statistical analyses performed were: analysis of variance (ANOVA) for each character; correlation analysis between each pair of characteres, generalized Mahalanobis distances (D2) among species and among populations within each species, canonical discriminant analysis (CDA), discriminant functions and cluster analysis. Flowering and biogeographical data were also considered. 
It was possible to conclude that there is a close concordance among the groups obtained through numerical taxonomy and the tradicional taxonomy, except by the fact that it was proposed that $M$. spectabilis var. moreliana should be considered a species.

It was also concluded that there is a north - south clinal variation among populations of $\mathrm{M}$. flavescens. The population of Juçari BA in the northern limit of $M$. flavescens' distribution considered here was classified as a race. In addition, populations of $M$. spectabilis show a north - south clinal variation, and Cascata - RJ population, in the northern limit of M. spectabilis' distribution considered is a race too. Differences in flowering season is an important factor in the diferentiation of the marginal populations in these species, because they difficult the gene flow among them. Both of $M$. regnellii populations are different races.

Populations which occur in Pleistocene refuge tend to become differentiated from the others, and in addition, the endemic species occur in these areas. 


\section{1.) INTRODUÇÃO}

Muitos trabalhos de genética, evolução, citologia e taxonomia têm sido feitos envolvendo a família Orchidaceae. Exemplos disto são os trabalhos de Sinoto $(1962 ; 1969)$ com citogenética; Pabst \& Dungs (1977) com taxonomia tradicional; Dupuy et al. (1985), Dufrêne et al. (1991), Tyteca \& Dufrêne (1993) com taxonomia numérica. A coleção de orquídeas do Departamento de Genética da Escola Superior de Agricultura "Luiz de Queiroz", tem fornecido material para muitos trabalhos deste tipo, podendo ser citados Blumenschein (1960) com citologia, Vencovsky (1960), Resende (1991) e Van den Berg (1996) com taxonomia numérica, Martins (1967; 1970) com genética ecológica e evolução e Resende (1991) com estudo de variabilidade através de marcadores isoenzimáticos.

A princípio, o gênero Miltonia compreendia tanto as espécies de "Miltonias" brasileiras, quanto as andinas. Em 1889, Godefroy-Lebeuf (citado por Sweet, 1978; Brieger \& Lückel, 1983) estabeleceu $\circ$ gênero Miltoniopsis, para o qual transferiu as espécies andinas, mantendo no gênero Miltonia somente as espécies brasileiras. Porém, esta classificação foi completamente reconhecida somente em 1976, por Dunsterville \& Garay. 
Apesar de ser um gênero pequeno, possuindo somente nove espécies, tem sido pouco estudado. Além disso, sua inclusão na subtribo Oncidinae não é muito clara, não sendo bem definidos os limites que o separam dos gêneros Oncidium e Odontoglossum. $O$ objetivo deste trabalho é analisar os padrōes de variabilidade intra e interespecífica em sete espécies do gênero Miltonia Ldl., coletadas em quase toda a área de distribuição geográfica no Brasil, e, no caso de $\mathrm{M}$. flavescens, também no Paraguai, que é o limite da distribuição do gênero na região sul do continente americano. Para tanto, foram utilizadas análises estatísticas univariadas e multivariadas, além de serem feitas considerações biogeográficas e quanto à fenologia. 


\section{2.) REVISĀO DE LITERATURA}

\section{1.) O gênero Miltonia Ldl. (Orchidaceae):}

\subsection{1.) Considerações gerais:}

A familia Orchidaceae é uma das maiores e mais diversas famílias de planta, incluindo cerca de $1 / 14$ a 1/10 das espécies de plantas superiores. É uma família bastante complexa e suas espécies apresentam adaptações altamente especializadas para atrair, iludir e manipular polinizadores, favorecendo a polinização cruzada (Dressler, 1990). Apesar disto, ocorre autogamia dentro da família, como é o caso da espécie Oeceoclades maculata (Mark \& Nir, 1988). Há casos em que a autogamia é obrigatória, devido à presença de cleistogamia, como ocorre em Maxillaria cleistogama Brieg. et lllg. (Illg, 1975).

Dentro da família Orchidaceae, a subtribo Oncidinae é a mais importante do Novo Mundo, estando subdividida em setenta e sete gêneros e um mil duzentas e trinta e duas espécies (Dressler, 1993) e se distribui pela América Tropical (Dressler, 1990; Dressler, 1993). Apresenta semelhança na estrutura da semente e na complexidade floral à subtribo Vandeae. Por outro lado, apresenta grande diversidade no número de cromossomos e nos caracteres vegetativos. A polinização na subtribo Oncidiinae se dá através de insetos (Dressler, 1993). 
Metade das espécies da subtribo Oncidiinae está dividida entre dois gêneros, Oncidium e Odontoglossum. Tradicionalmente, estes gêneros têm sido separados pelo ângulo formado entre o labelo e a coluna, apesar deste caráter ser bastante variável e não separar claramente os dois grupos (Dressler, 1993). Este autor cita que Chase afirma não haver separação clara no complexo Miltonia/Oncidium, sendo que seria mais prático abandonar os termos Miltonia e Odontoglossum, por enquanto, e usar o conceito Oncidium de forma mais ampla, até que uma classificação natural mais clara seja viável.

Segundo Chase \& Palmer (1992), com base em resultados de análise de DNA, foram reconhecidas dezesseis clades distintas dentro de Oncidiinae. Porém, são necessários mais dados sobre DNA de cloroplastos (ou outros métodos) para determinar o padrão das relações dentro de Oncidinae, ficando claro que uma nova classificação é necessária (Dressler, 1993).

O gênero Miltonia encontra-se na subtribo Oncidiinae, na tribo Cymbideae Pfitzer, subfamília Vandoideae (Dressler 1990; 1993).

O gênero Miltonia foi estabelecido por Lindley (1837), sendo Miltonia spectabilis Ldl. a primeira espécie nele classificada. Segundo Sweet (1978) este gênero é baseado em espécies brasileiras, diferenciando-se portanto das espécies andinas, conhecidas como "amores-perfeitos", as quais foram classificadas como pertencentes ao gênero Miltoniopsis por Godefroy-Lebeuf (1889) (citado por Sweet, 1978; Brieger \& Lückel, 1983). As espécies deste gênero diferenciam-se das miltonias brasileiras morfologicamente, e quanto aos tratos culturais. $O$ gênero Miltonia apresenta plantas com rizoma trepador, dois

${ }^{1}$ Comunicação pessoal 
pseudobulbos viçosos e uma coluna auriculada, com cavidade frontal, cujos lados são firmemente unidos com os nectaríferos da base do labelo. A coloração dos pseudobulbos e das folhas é verde-amarelado. Já o gênero Miltoniopsis é caracterizado por pseudobulbos agregados e coluna exauriculada, que é unida ao labelo, embora sua elevação central em forma de quilha não apresente cavidade. Os pseudobulbos e as folhas são verde-azulado e acinzentados (Sweet, 1978).

Não há definição clara da classificação taxonômica deste complexo. Segundo Brieger \& Lückel (1983), características importantes usadas para delimitar os gêneros na família Oncidinae são os detalhes estruturais dos calos, o ângulo entre o labelo e a coluna, a maneira de adnexão do labelo à base da coluna, o grau de curvatura do labelo, políneas, entre outros, sendo que combinações de caracteres são mais importantes que um caráter isolado. Porém, a opinião dos botânicos difere na avaliação e seleção dos caracteres. Brieger \& Lückel (1983) referem-se ao fato de que o complexo Miltonia compreende espécies bem conhecidas dos gêneros Miltonia e Miltoniopsis e que as espécies do complexo Odontoglossum laeve têm sido atribuídas, alternativamente, aos gêneros Oncidium, Odontoglossum, Cyrtopodium e Miltonia. Para estas espécies, os autores propuseram um novo gênero, Miltonioides, baseado no fato de que estas espécies não apresentam calosidade na base do labelo, típica de Oncidium e Cyrtopodium, nem a adnexão entre o labelo e a coluna, presente em Odontoglossum e nem características relevantes encontradas em Miltonia e Miltoniopsis.

Segundo Brieger \& Lückel (1983), ○ complexo Odontoglossum lavae apresenta, provavelmente, origem monofilética, apesar de suas espécies serem distintas das dos gêneros Miltonia e 
Miltoniopsis, embora seja difícil definir características que demonstrem isto. Dressler \& Williams (1975) (citados por Brieger \& Lückel, 1983)² chamaram este complexo de Oncidiglossum confusum. GodefroyLebeuf (1889) (citado por Sweet, 1978; Brieger \& Lückel, 1983) separou Miltoniopsis de Miltonia, o que somente foi completamente reconhecido por Dunsterville \& Garay em 1976.

Brieger \& Lückel (1983) estabeleceram o gênero Miltonioides, para onde transferiram Miltonia warscewiczii Rchb. f.. Mantiveram M. clowesii Ldl. e M. flavescens (Ldl.) Ldl. no gênero Miltonia, apesar delas serem diferentes deste gênero em alguns aspectos e estabeleceram $\circ$ gênero Anneliesia, para $\circ$ qual transferiram $M$. candida Ldl.. Estes autores, portanto, discordam de Dressler \& Williams (1970), que estabeleceram o gênero Cischwenfia e discutiram a possibilidade de transferir para ele a espécie M. candida Ldl.. Esta transferência não foi realizada devido à necessidade de maiores evidências para tanto.

Pabst \& Dungs (1977) descreveram duas alianças dentro do gênero Miltonia, ou seja a aliança de $M$. spectabilis e a aliança de $M$. clowesii. A primeira se caracteriza por plantas com haste floral achatada e brácteas com o mesmo comprimento do ovário. A esta aliança pertencem as espécies $M$. anceps, $M$. flavescens e $M$. spectabilis. A segunda aliança, a qual pertencem as espécies M. candida, M. clowesii,

2 Dressler, R. L. \& Williams, N. H. The Oncidoglossum confusum complex. Orquidea (Mex), 4(11): 322-52, 1975. 
M. cuneata, M. kayasimae, M. regnellii e M. russeliana, é caracterizada por plantas com haste floral roliça e brácteas muito mais curtas que o ovário. Além disto, estes autores também listam híbridos naturais, os quais estão descritos nas tabelas 1 e 2 .

TABELA 1. Híbridos intragenéricos naturais em Miltonia Ldl. (Orchidaceae), espécies parentais e estados brasileiros onde ocorrem.

\begin{tabular}{|c|c|c|}
\hline HBbrido Intragenérico & Cruzamento & Estado \\
\hline$x$ binotii Cogn. & M. condida XM. regnellii & RJ \\
\hline X bluntii Rchb. $f$. & $\begin{array}{l}\text { M. spectabilis } X \text { M. clowesii (M. } \\
\text { peetersiana Rchb. f.) }\end{array}$ & ES, RJ \\
\hline$X$ castanea Rolfe & $\begin{array}{l}\text { M. clowesii X M. regnellii (M. } \\
\text { lawrenceana Cogn.l }\end{array}$ & RJ \\
\hline$X$ festiva (Rchb. f.) Nichols & $\begin{array}{l}\text { M. spectabilis X M. flavescens (M. } \\
\text { cyrtochiloides Barb. Rodr.) }\end{array}$ & ES \\
\hline$X$ cogniauxiae Peeters & M. spectabilis $X$ M. regnellii & RJ \\
\hline X rosina Barb. Rodr. & M. cuneata X M. spectabilis & RJ \\
\hline X lamarcheana Rchb. f. & $\begin{array}{l}\text { M. candida X M. clowesii (M. } \\
\text { joiseyana O'Brien) }\end{array}$ & ES \\
\hline X leucoglossa Hort. & M. candida X M. spectabilis & ES \\
\hline
\end{tabular}

Fonte: Pabst \& Dungs (1977).

TABELA 2. Híbridos intergenéricos naturais em Miltonia Ldl. (Orchidaceae), gêneros parentais e estados brasileiros onde ocorrem.

\begin{tabular}{llll}
\hline $\begin{array}{c}\text { Tipo de hibrido inter- } \\
\text { genérico }\end{array}$ & Hibrido intergenérico & Cruzamento & Estado \\
\hline X MILPASIA & X Lesley-garay Moir & $\begin{array}{l}\text { Miltonia spectabilis } \\
\text { Aspasia lunata }\end{array}$ & $\mathrm{X}$ \\
X MILTONIDIUM & $\mathrm{X}$ salvadoi Pabst \& Mello & $\begin{array}{l}\text { Miltonia X Oncidium } \\
\text { PJ }\end{array}$ & RJ \\
\hline
\end{tabular}

Fonte: Pabst \& Dungs (1977).

Embora M. Cogniauxiae, proveniente do cruzamento entre M. spectabilis e M. regnellii seja considerado híbrido natural por Pabst \& 
Dungs (1977), é citado por Baker (1990) como sendo o primeiro híbrido artificial dentro do gênero Miltonia.

Sweet (1978) relaciona a existência de oito híbridos naturais envolvendo Miltonia. Dressler (1990) cita três híbridos naturais intergenéricos na subtribo Oncidiinae, todos do Brasil. Estes híbridos são provenientes de cruzamentos entre Oncidium X Ornithophora, Oncidium $X$ Miltonia e Aspasia X Miltonia. Cita também que há híbridos interespecíficos envolvendo o gênero Miltonia, sendo que alguns deles podem se tornar híbridos intergenéricos se o gênero Miltonia for subdividido. Esta divisão seria baseada somente na forma do labelo, porém a análise dos híbridos naturais sugere que esta divisão não melhoraria a classificação atual.

Ainda segundo Sweet (1978) a subtribo Oncidiinae oferece vários exemplos de classificação artificial. Até recentemente, Oncidium, Odontoglossum e Miltonia eram gêneros caracterizados primeiramente pela forma das flores e 0 ângulo entre 0 labelo e a coluna. Recentemente, os autores têm separado as "Miltonias" andinas das brasileiras, sendo aquelas classificadas como Miltoniopsis e as demais transferidas para Oncidium.

Segundo Hoehne (1949) as espécies do gênero Miltonia apresentam labelo levemente ou totalmente lobado, largo, algumas vezes lanceolado-oblongado. As inflorescências são rácimos monantos ou com até quinze flores. Estas, muitas vezes, parecem flores de Oncidium. O autor considera que mais de vinte espécies foram descritas na região tropical da América, as quais crescem tanto nas matas secas quanto nas úmidas, formando geralmente touceiras. Porém, segundo Baker \& Baker, (1995), considera-se, atualmente, que o gênero Miltonia é 
formado por nove espécies, todas brasileiras: M. anceps, M. candida, M. clowesii, M. cuneata, M. flavescens, M. kayasimae, M. regnellii, M. russeliana e M. spectabilis. Há duas espécies adicionais que foram consideradas miltonias - M. schroederiana e M. warscewiczii - mas foram recentemente reclassificadas, sendo agora conhecidas como Oncidium schroederiana e Oncidium fuscatum, respectivamente.

Com exceção de $M$. anceps, as espécies aqui estudadas serão descritas em seguida, de acordo com MCQueen \& McQueen (1993), de onde também foram extraídas as fotos $\underline{b}$ a $\underline{h}$ da Figura 1.

a) Miltonia anceps (Klotzsch) Ldl.: apresenta inflorescências uniformes e sépalas e pétalas obtusas. O labelo tem forma aguda. (Hoehne, 1930). Outros sinônimos são Odontoglossum anceps, M. pinellii e Oncidium anceps (Martins, 1970).

b) Miltonia clowesii Lindley: descoberta por Gardner e descrita por Lindley em 1839. Odontoglossum clowesii e Brassia clowesii são sinônimos. Esta espécie é encontrada nas montanhas mais frias do Rio de Janeiro, Espírito Santo e Minas Gerais. Os pseudobulbos são verdeoliva, comprimento entre 7,5 e $10,0 \mathrm{~cm}$ e largura entre 2,5 e $4,0 \mathrm{~cm}$ ficam separados sobre o robusto rizoma. Eles são achatados e medem $2,0 \mathrm{~cm}$ de largura perto da base e $1,0 \mathrm{~cm}$ no ápice. As duas folhas apicais, de 22,0 a $65,0 \mathrm{~cm}$ de comprimento e 1,8 a $2,5 \mathrm{~cm}$ de largura, são dobradas na base e têm ápice agudo. Inflorescências de 35,0 a 65,0 $\mathrm{cm}$ são produzidas no outono e a partir da base dos pseudobulbos. Elas suportam de cinco a dez flores de 7,0 a $8,0 \mathrm{~cm}$ de comprimento e 5,0 a $6,0 \mathrm{~cm}$ de largura. As tépalas são amarelo-marrom e possuem pontas agudas. Possuem manchas castanhas. A sépala dorsal tem $3,5 \mathrm{~cm}$ de 
comprimento e $1,0 \mathrm{~cm}$ de largura e as sépalas laterais são um pouco mais longas e mais finas. As pétalas são similares, com 3,0 a $3,5 \mathrm{~cm}$ de comprimento, com margens onduladas. O labelo em forma de violino tem de 3,0 a $3,2 \mathrm{~cm}$ de largura. As extremidades da metade basal, que são verde-escuro são fortemente recurvadas. Há de cinco a sete carenas na base.

c) Miltonia cuneata Lindley: esta espécie foi descrita por Lindley em 1844 e suas sinonímias são M. speciosa e Oncidium speciosum. É encontrada nas montanhas mais frias e também nas terras mais baixas e úmidas do Espírito Santo, Rio de Janeiro e São Paulo. Tratase de uma espécie epífita, onde os pseudobulbos podem ser agrupados ou bem separados sobre o rizoma. Estes pseudobulbos, que medem de 4,0 a $7,5 \mathrm{~cm}$ de altura (ocasionalmente $10,0 \mathrm{~cm}$ ), são de ovalados a oblongos, um pouco comprimidos a $3,0 \mathrm{~cm}$ da base. Há de duas a quatro brácteas na base e duas ou três folhas apicais, de oblongas a lanceoladas, com 20,0 a $45,0 \mathrm{~cm}$ de comprimento e 3,0 a $4,0 \mathrm{~cm}$ de largura. Inflorescências produzidas no final do inverno e na primavera, medem 30,0 a $60,0 \mathrm{~cm}$ de comprimento e suportam de quatro a oito flores, as quais duram cerca de um mês. As tépalas, mais ou menos lanceoladas, são castanhas, com seções apicais recurvadas e amarelas claras e freqüentemente poucas barras ou listras amarelas perto da base. Possuem margens onduladas. As sépalas laterais e as pétalas têm de 3,2 a 4,0 cm de comprimento e 1,4 ou mais $\mathrm{cm}$ de largura, enquanto a sépala dorsal é mais curta. O labelo branco de 3,5 a $4,0 \mathrm{~cm}$ de comprimento é mais ou menos difundido com verde. Apresenta duas longas carenas, que são algumas vezes marcados com verde e rosa. 
Perto da base, são cobertos com pêlos finos. As estreitas expansões da coluna se juntam acima da antera.

d) Miltonia flavescens (Ldl.) Lindley: esta espécie foi descrita por Lindley em 1833, como Cyrtochilum flavescens, que a transferiu para o gênero Miltonia em 1839. Oncidium flavescens e Cyrtochilum stellatum são sinonímias. Trata-se de uma espécie amplamente distribuída em terras baixas quentes desde Pernambuco até o Norte do Rio Grande do Sul, ocorrendo também no Paraguai e Argentina. Os pseudobulbos são achatados e ficam $3,0 \mathrm{~cm}$ separados sobre o robusto rizoma. Eles variam de amarelo-esverdeado a verde, mais ou menos oblongos, com 5,0 a $14,0 \mathrm{~cm}$ de comprimento e 2,0 a $2,5 \mathrm{~cm}$ de largura. Há uma ou duas brácteas na base e duas folhas na forma de cordão de 16,0 a $35,0 \mathrm{~cm}$ de comprimento no ápice. As inflorescências, produzidas no final da primavera e no verão são algumas vezes achatadas, medem $1,0 \mathrm{~m}$ ou mais e saem da base do pseudobulbo. Possuem sete a catorze flores de $7,5 \mathrm{~cm}$. As tépalas amarelo-pálido são lineares a oblongas, com ápice agudo. As sépalas têm de 3,5 a $5,0 \mathrm{~cm}$ de comprimento e 0,4 a $0,6 \mathrm{~cm}$ de largura, enquanto as pétalas são um pouco mais largas e curtas. $O$ labelo de $2,5 \mathrm{~cm}$ de largura é mais ou menos oblongo e com margens onduladas, que são algumas vezes voltados para cima. O labelo é branco com listras vermelho-púrpuras, que podem formar quatro a seis linhas radiais sobre a pequena e pilosa metade basal.

e) Miltonia regnellii: Reichenbach (f.): apresenta como sinonímias M. cereola e Oncidium regnellii. Embora, segundo Regnell esta espécie tenha sido descoberta em Minas Gerais, Pabst e Dungs 
(1977) listaram-na apenas nas regiões montanhosas mais frias de São Paulo, Paraná, Santa Catarina e Rio Grande do Sul, podendo ocorrer também no Rio de Janeiro. Os pseudobulbos variam de amareloesverdeado a verde e são achatados e afilados. Medem de 5,0 a 12,0 $\mathrm{cm}$ de comprimento e 1,2 a $4,0 \mathrm{~cm}$ de largura. Próximo da base são separados e estão $4,0 \mathrm{~cm}$ sobre o rizoma robusto. As brácteas, de duas a cinco, são agrupadas na base, com duas folhas em forma de cordão no ápice. Estas possuem 19,0 a 25,0 cm de comprimento e 1,0 a $1,8 \mathrm{~cm}$ de largura, dobradas na base e irregularmente chanfrados no ápice. As inflorescências, produzidas no outono, são arqueadas, medem de 30,0 a $55,0 \mathrm{~cm}$ de comprimento a partir da base do pseudobulbo e carregam três a cinco flores de 5,0 a $7,5 \mathrm{~cm}$. As tépalas são brancas e podem apresentar matiz rosa claro próximo à base. As sépalas lanceoladas têm de 3,0 a $3,5 \mathrm{~cm}$ de comprimento e cerca de $1,0 \mathrm{~cm}$ de largura, com carena atrás das sépalas laterais. As pétalas medem de 2,7 a $3,0 \mathrm{~cm}$ de comprimento. O labelo verde pálido tem várias listas violeta-escuro e extremidades brancas ou cremes. Mede de 3,0 a $3,5 \mathrm{~cm}$ de comprimento. Há três sulcos principais e outros mais curtos na base.

f) Miltonia russeliana (Ldl.) Lindley: foi descrita por Lindley em 1836 como Oncidium russelianum. Em 1840, ele transferiu a espécie para - gênero Miltonia. É também conhecida como M. quadrijuga. Suas áreas de ocorrência são as regiões montanhosas frias do Rio de Janeiro, São Paulo, Santa Catarina, Paraná e Rio Grande do Sul. Os pseudobulbos verde-oliva são pouco achatados, ovais a oblongos e agrupados sobre o rizoma. Medem 5,0 a $7,0 \mathrm{~cm}$ de altura e têm duas brácteas na base e duas folhas na forma de cordão e estreitas medindo 
de 15,0 a $25,0 \mathrm{~cm}$ de comprimento no ápice. No final do outono ou no inverno, solta inflorescências de eretas a arqueadas, medindo 40,0 a $60,0 \mathrm{~cm}$ de comprimento a partir da base do pseudobulbo. Há de cinco a nove flores por haste, as quais não se abrem completamente. As tépalas são vermelho-amarronzado, sendo que na região apical são amarelas claras e mais ou menos recurvadas. As sépalas têm mais ou menos $3,0 \mathrm{~cm}$ de comprimento e $1,0 \mathrm{~cm}$ de largura, enquanto as pétalas apresentam $2,6 \mathrm{~cm}$ de comprimento e são um pouco mais largas que as sépalas. O labelo oblongo tem $3,0 \mathrm{~cm}$ de comprimento e 1,0 de largura e são rosa-lilás nos dois terços basais e branco ou amarelo claro no terço apical recurvado. Há um afunilamento logo abaixo do terço apical e três carenas sobre o disco.

g) Miltonia spectabilis Lindley: esta espécie, que é o tipo para o gênero, foi levada do Brasil para a Inglaterra por Fry em 1835 , tendo sido descrita por Lindley em 1837. Apresenta como sinônimo Oncidium spectabilis. Esta espécie ocorre em regiões montanhosas frias e terras baixas quentes, crescendo epifiticamente no leste do Brasil desde Pernambuco até São Paulo. Ocorre também na Venezuela. Os pseudobulbos são amarelo-esverdeado e têm 1,0 a 2,0 cm. Eles são achatados, ovais a oblongos, medem 4,0 a $10,0 \mathrm{~cm}$ de comprimento e cerca de 2,0 cm de largura. Há uma ou duas brácteas na base e um par de folhas na forma de cordão estreitas de 10,0 a $30,0 \mathrm{~cm}$ de comprimento no ápice. Um ou duas flores nascem por inflorescência no final da primavera ou começo do verão. As inflorescências medem 7,0 a $15,0 \mathrm{~cm}$ de comprimento, sendo, às vezes, maiores. As sépalas são oblongas a lanceoladas, brancas, com tonalidade rosa mais ou menos 
difundida. As sépalas carenadas medem 3,5 a $4,0 \mathrm{~cm}$ de comprimento e cerca de $1,6 \mathrm{~cm}$ de largura. As pétalas um pouco maiores são geralmente recurvadas. O labelo possui só um lobo e mede 4,5 a 5,0 cm de comprimento e acima de $4,6 \mathrm{~cm}$ de largura. É usualmente rosa, e na base é vermelho-púrpura profundo, com veias mais escuras. As margens onduladas são algumas vezes brancas ou verde-claro. As expansões de oblongas a triangulares da coluna são usualmente rosa-purpúreo.

h) Miltonia spectabilis var. moreliana (Henfrey) : trata-se de uma variedade de M. spectabilis Ldl.. Henfrey reconheceu-a como uma variedade de M. spectabilis, enquanto Warner (citado por McQueen \& MCQueen, 1993) preferia considerá-la uma espécie separada, baseado na diferença de coloração. M. spectabilis var. moreliana tem pseudobulbo achatado semelhante ao da espécie tipo. Ficam 1,0 a 2,0 cm separados sobre o rizoma e são cobertos por brácteas. Apresenta uma ou duas flores, que duram por seis semanas. Estas flores possuem cerca de $10 \mathrm{~cm}$ de comprimento, sendo um pouco maiores que as flores de M. spectabilis. A coloração é variável, mas as pétalas e sépalas são comumente ameixa-purpúreo com base branca ou rosa claro. $O$ grande labelo em forma de saia é rosa-purpúreo claro, com uma rede de veias mais escuras. Martins (1967), também sugere que seja considerada espécie distinta. M. moreliana e M. spectabilis var. purpureo-violaceae são sinônimos à $M$. spectabilis var. moreliana. 


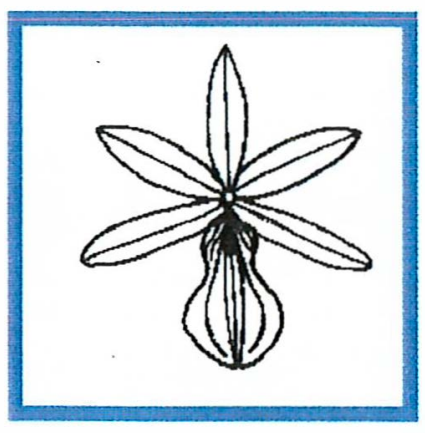

a) M. anceps (Klotzsch) Ldl.

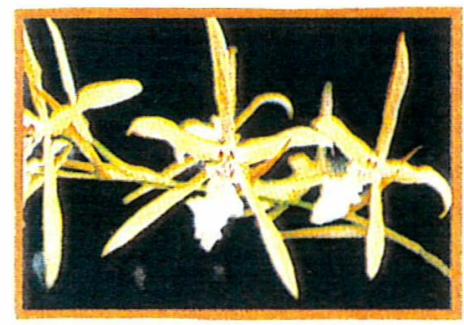

d) M. flavescens (Ldl.) Lindley

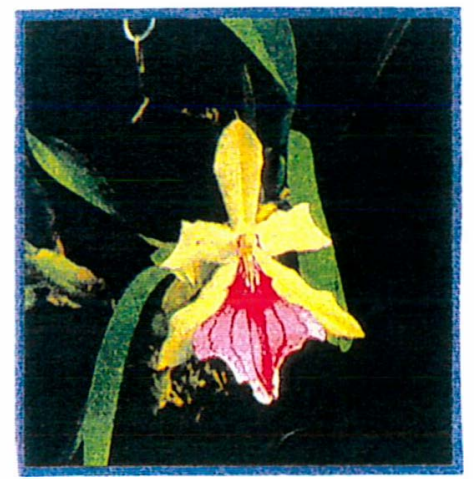

g) M. spectabilis Lindley

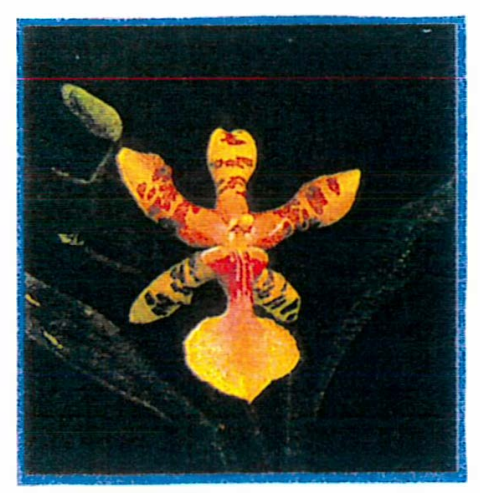

b) M. clowesii Lindley

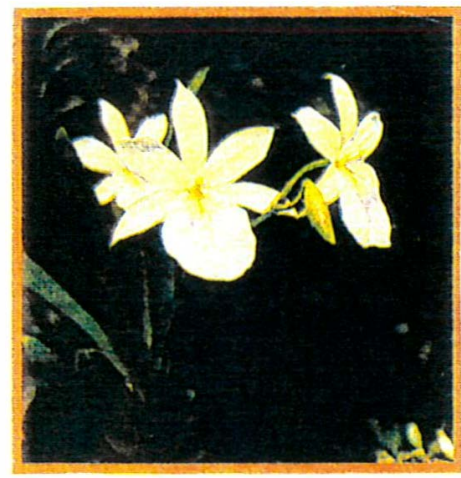

e) M. regnellii Reichenbach (f.)

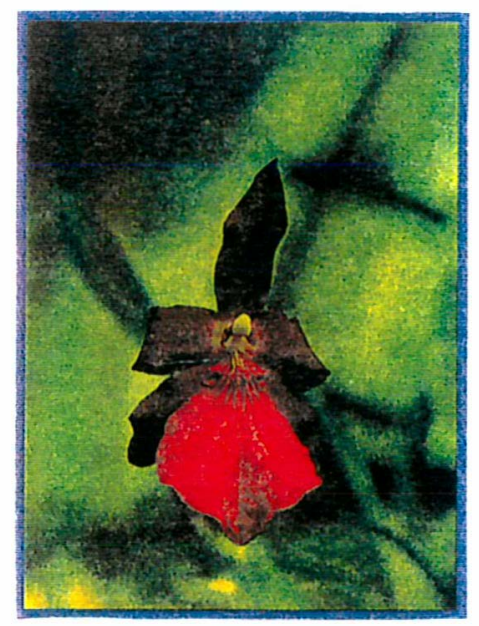

h) M. spectabilis var. moreliana Henfrey

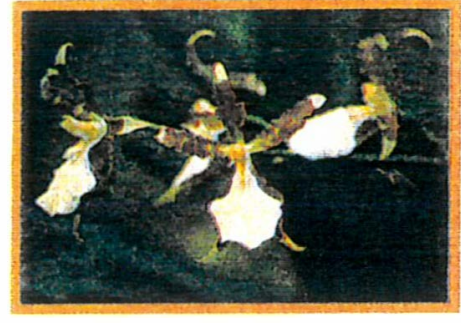

c) M. cuneata Lindley

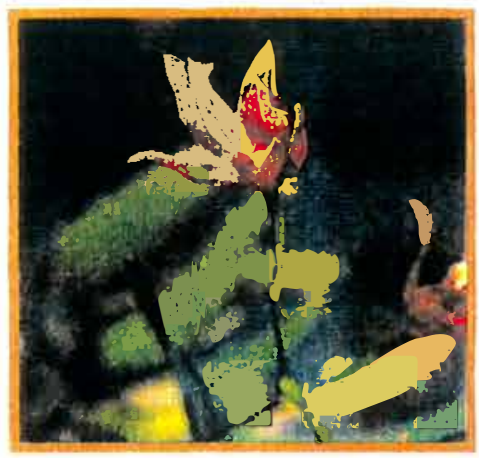

f) M. russeliana (Ldl.) Lindley

FIGURA 1. Representações das flores dos taxa analisados. Fonte: McQueen \& McQueen (1993): fotos $\underline{b}$ a $\underline{h}$. 


\subsection{2.) Considerações genéticas:}

O número de cromossomos na subtribo Oncidinae é bastante variado: $10,14,24,26,28,30,36,38,40,42,44,48,50,56$ e 60 (Dressler, 1990). Considerando apenas as espécies aqui estudadas observamos que Miltonia anceps apresenta $2 n=48$ cromossomos (Martins, 1970). Em estudos com Miltonia flavescens, Sinoto (1962; 1969) e Charanasri et al. (1973) observaram que esta espécie apresenta $2 n=60$ cromossomos, embora Blumenschein (1960) tenha observado $2 n=56$ e Martins (1970) tenha encontrado variação no número de cromossomos entre $2 n=56,2 n=58$ e $2 n=60$, dependendo da região geográfica para esta mesma espécie. Sinoto, $(1962 ; 1969)$ observou $2 n=60$ cromossomos em M. regnellii, embora Martins (1970) tenha observado $2 n=48$ cromossomos para esta espécie. M. spectabilis também apresenta 2n=60 cromossomos (Sinoto, 1962; 1969; Martins, 1967; Charanasri \& Kamemoto, 1975) e M. spectabilis var. moreliana apresenta $2 n=86$ cromossomos (Sinoto, 1962; 1969). Número haplóide de cromossomos igual a cinco ou a sete é considerado número básico para esta subtribo. Porém, estes são números muito baixos para as orquídeas e dificilmente esperados como caráter primitivo de orquídeas altamente evoluídas, como é o caso do daquelas pertencentes ao gênero Psygomorchis, onde o número de cromossomos parece ter sido reduzido de um número maior (Dressler, 1990). Chase (1986) sugere que $2 n=60$ seja 0 número de cromossomos primitivo para $\circ$ gênero e Chase \& Palmer (1992) sugerem que o número de cromossomos de $n=28$ ou $n=30$ como condição ancestral para a subtribo Oncidiinae. 
2.2.) Taxonomia Numérica, Fenética, Morfometria e Análise Multivariada.

\subsection{1.) Considerações gerais:}

Taxonomia Numérica consiste em agrupar unidades taxonômicas em taxa, através de méłodos numéricos, com base nos estados dos caracteres avaliados. Estes estados podem ser definidos como qualquer propriedade que possa variar entre unidades taxonômicas e os valores que estas possam assumir (Sneath \& Sokal, 1973). Estas unidades taxonômicas são denominadas OTU's (Operational Taxonomic Units) (Sokal \& Sneath, 1963). Segundo Sneath (1995) a Taxonomia Numérica tem extensão mais ampla do que simplesmente realizar estudos fenéticos. Novas áreas de expansão da Taxonomia Numérica são a Filogenética Numérica, a Sistemática Molecular, a Identificação Numérica e a Morfometria.

Duncan \& Baum (1981) definem Fenética como uma forma de classificação de organismos (OTU's) com base em suas semelhanças ou diferenças, sendo que este critério de classificação não leva em consideração os processos evolutivos que conduziram a estas semelhanças ou dessemelhanças. Além disso, os caracteres considerados na estimativa e formulação da classificação não têm, inicialmente, pesos diferenciados.

Várias são as medidas de similaridade ou de suas medidas complementares, que são as dissimilaridades ou distâncias, sendo que elas variam em função da natureza dos caracteres, ou seja, se eles são binários, qualitativos com mais de dois estados ou quantitativos. 
Pearson (1926) criou uma das primeiras medidas de dissimilaridade, a qual ele denominou Coeficiente de Semelhança Racial (CRL), modificado por Vencovsky (1960) para Coeficiente de Semelhança Morfológica (CSM). As distâncias Euclidiana, Euclidiana Média e Euclidiana Quadrada, são baseadas no teorema de Pitágoras e são hoje muito difundidas. A Distância $D^{2}$ de Mahalanobis, também muito usada, apresenta como vantagem o fato de descontar as correlações entre as variáveis. Há ainda outras distâncias menos usadas, como por exemplo a de Manhattan (Manly, 1995).

Finalmente, Morfometria consiste em descrever, analisar e interpretar quantitativamente a forma e a variação da forma dentro da Biologia, sendo portanto uma das áreas mais importantes de pesquisa. Técnicas de descrição e comparação de formas de estruturas são necessárias em qualquer estudo de sistemática (fenético ou cladístico), que seja baseado na morfologia de organismos. Medidas de diversidade morfológica são de interesse em estudos genéticos e ecológicos (Rohlf, 1990).

Importante ferramenta para estudos dentro da Taxonomia Numérica são as técnicas de Análise Multivariada, que constituem uma área da Estatística, que provê métodos estatísticos para estudar relações de variáveis em dados intercorrelacionados. Como várias variáveis podem ser consideradas simultaneamente, podem ser feitas interpretações mais abrangentes do que as que seriam possiveis através de estatística univariada. Através do uso destas técnicas, é possivel descrever o padrão de relação entre os objetos (indivíduos, unidades amostrais, taxa, etc.) por ordenação (redução de uma matriz de distâncias ou similaridades entre os atributos ou entre os objetos para 
uma ou mais dimensões) ou por análise de agrupamento (classificação de objetos em categorias hierárquicas com base em matriz de similaridade entre objetos) (James \& McCulloch, 1990).

Segundo estes autores a análise de componentes principais tem por objetivos descrever os dados, reduzindo a poucas dimensões a matriz de distâncias entre os objetos. Segundo Manly (1995) trata-se de um dos mais simples métodos multivariados. O objetivo desta análise é considerar $p$ variáveis $X_{1}, X_{2}, \ldots, X_{p}$, e encontrar combinações entre elas que produzam índices não correlacionados $Z_{1}, Z_{2}, \ldots, Z_{p}$. A perda de correlações é uma propriedade bastante útil porque significa que os índices estão medindo diferentes "dimensões" dos dados. Os índices são ordenados de forma que $Z_{1}$ tenha a maior porção da variância total, $Z_{2}$ a segunda maior parte da variância total e assim sucessivamente. Ou seja, $\operatorname{var}\left(Z_{1}\right) \geq \operatorname{var}\left(Z_{2}\right) \geq \ldots \geq \operatorname{var}\left(Z_{p}\right)$, onde $\operatorname{var}\left(Z_{i}\right)$ denota a variância de $Z_{i}$ no grupo de dados considerado. Os Z's são chamados de componentes principais. A Análise de Componentes Principais (PCA) encontra os autovalores da matriz de covariância amostral. Estes autovalores são as variâncias dos componentes principais. Há $p$ destes autovalores. As variáveis originais relacionam-se linearmente com cada componente principal obtido. Estas variáveis se relacionam a cada componente, estando associadas a coeficientes e correspondem aos elementos dos autovetores.

A análise de variáveis canônicas ou análise discriminante deriva da análise de componentes principais, diferindo no fato de que aqui, cada eixo maximiza a separação entre grupos previamente dados. Esta análise também apresenta como resultado uma avaliação da classificação de cada amostra, sendo que cada amostra é colocada 
no grupo cujo centróide seja mais semelhante ao seu valor. A distância entre a amostra e o valor do centróide é medida pela Distância de Mahalanobis. Além disso, distâncias entre grupos também equivalem à Distâncias de Mahalanobis. Este método apresenta como desvantagens a necessidade de multinormalidade e a exigência de que o número de variáveis seja igual ou menor que o número de observações dentro de cada grupo. Porém, caso estas exigências não sejam supridas, o método pode ser utilizado como exploratório e produzir resultados gráficos bastante úteis (Manly, 1995).

A análise de agrupamentos tem por objetivos agrupar os objetos julgados como similares, de acordo com as distâncias ou similaridades entre eles, além de reduzir um número de $n$ objetos para um número $g$ de grupos de objetos (James \& McCulloch, 1990).

2.2.2.) Exemplos de aplicação de Taxonomia Numérica na familia Orchidaceae:

Vencovsky (1960) estudou três espécies do gênero Hormidium, hoje gênero Encyclia e duas espécies do gênero Brassavola. Este autor realizou análise de variância para cada caráter estudado, visando estimar o grau de uniformidade de cada grupo e o grau de diversificação entre os grupos. Foi feita análise de correlação interclasses entre todos os pares de combinações de caracteres para a espécie Hormidium fragans, foi calculada a correlação intraclasse e o coeficiente de transgressão. Aplicou o teste "t" e calculou o Coeficiente de Semelhança Morfológica de Pearson, modificando-o para Coeficiente de Semelhança Racial. Também foi considerada a época 
de florescimento de cada espécie. Este autor encontrou, como resultado destas análises, maior dessemelhança morfológica entre as espécies $H$. fragans e $B$. cebolleta e maior semelhança entre $H$. glumaceum e $H$. almasyi e as três populações de $B$. perrinii.

Brieger et al. (1963) usaram a Distância de Mahalanobis no estudo de onze espécies do gênero Cattleya Ldl. e analisaram três grupos de dados, cada um referente a seis caracteres florais. Ao iniciar as análises, os autores já sabiam de antemão a provável relação entre as onze espécies, embora houvesse dúvida em alguns casos se se tratava de espécie ou subespécie. Os autores concluiram que a Distância de Mahalanobis oferece contribuições de grande valor, quando aliada às informações da taxonomia clássica.

Cunha Filho (1966) analisou espécies de orquídeas do gênero Laelia seção Parviflorae através da distância de Mahalanobis, agrupando-as em sete grupos diferentes. Avaliou, através de triângulos de distâncias a possibilidade de algumas espécies terem sido resultantes de hibridação, sendo que os resultados obtidos através deste método foram concordantes com dados citológicos e morfológicos. A origem hibrida da espécie Laelia mixta foi confirmada posteriormente por Resende (1991).

Martins (1967) estudou várias populações da espécie $M$. spectabilis e de $M$. spectabilis var. moreliana. Utilizaram-se doze caracteres, calculando para cada um deles a média, o desvio padrão e o coeficiente de variação, aplicando em seguida o teste "t", para verificar se ocorria ou não descontinuidade entre os dois grupos. Foi também feito estudo de época de florescimento, nas condições de Piracicaba, anotando o número de plantas que floresciam por mês. $\bigcirc$ 
autor concluiu que M. spectabilis var. spectabilis e M. spectabilis var. mo:eliana devem ser consideradas duas espécies alopátricas.

Martins (1970) estudou populações das espécies $M$. flavescens, $M$ regnellii e $M$. anceps, visando descrever os tipos de variação intra e interespecíficas e sua implicação taxonômica e evolutiva, levando em consideração as regiões fitogeográficas e ecológicas. Foram calculados médias, desvios padrões e coeficientes de variação para cada caráter avaliado. Foi também levada em consideração a época de florescimento de cada espécie, através de contagens do número de flores por mês, durante três anos. Foram estimadas equações de regressão linear para cada caráter. Além disso, foram feitas contagens cromossômicas para cada espécie, assim como determinação na variação da forma do labelo por região geográfica. $\bigcirc$ autor concluiu que houve variação clinal entre quatro das cinco populações estudadas em $M$. flavescens. Porém, os espécimes da região 5, no limite norte da distribuição geográfica, devem ser considerados semiespécie simpátrica com relação aos das espécies das demais regiões. A espécie $M$. quadrijuga Dus \& Kränz e as variedades stellata Regel e grandiflora Regel pertencem à M. flavescens. M. regnellii Reichb. $f .$, variedade citrina deve ser mantida. $E$, finalmente, $M$. anceps Ldl. não permitiu caracterizar qualquer categoria taxonômica, pois apresentou variação irregular.

DuPuy et al. (1985) analisaram, através de PCA e Análise de Agrupamento, Cymbidium Sw. (Orchidaceae) do Sudeste da Ásia. Estes autores propuseram hibridação como origem de duas espécies (C. wilsonii Rolfe e C. schroederi Rolfe). C. i'ansonii Rolfe é reduzida ao estado de variedade dentro de C. lowianum Reichb. f.. 
Resende (1991) estudou relações fenéticas dentro de gênero Laelia (Orchidaceae), através de análises isoenzimáticas, citogenéticas e de taxonomia numérica. Nesta última, utilizou treze caracteres morfológicos, avaliados por análises univariadas (ANAVA) e multivariadas (Distâncias Euclideana e de Mahalanobis, PCA e CDA). Como resultado, estabeleceu dois grupos principais, sendo um deles subdividido em quatro grupos. Confirmou que a espécie Laelia mixta teve origem por hibridação.

Dufrêne et al. (1991) analisaram características quantitativas de trinta e cinco populações de Dactylorhiza maculata (L.) através de Distância de Mahalanobis, PCA, CDA e métodos de grupamento. Foram feitas também análises de caracteres qualitativos, citológicas e observações ecológicas. Foram reconhecidas quatro unidades específicas: $D$. maculata, $D$. fuchsii, $D$. saccifera e $D$. caramulensis. Eles concluíram que características florais têm papel fundamental na distinção taxonômica.

Tyłeca \& Dufrêne (1993) compararam quatro coeficientes de distâncias usando quatro grupos de dados compostos por amostras de populações, provenientes do Oeste Europeu, dos gêneros Dactylorhiza, Orchis e Epipactis (Orchidaceae). O comportamento dos coeficientes de distâncias foi avaliado através de: a) qualidade dos agrupamentos obtidos através de cinco métodos clássicos; b) teste de Mantel feito a partir de uma matriz de distâncias baseadas em conhecimento prévio; c) resultado obtido com o modelo de k-médias; d) diagrama de coordenadas principais. A Distância de Mahalanobis, baseada em matriz de dispersão, aparentemente ofereceu melhor resultado. A distância baseada no método "Common Principal 
Component", usado com transformação log, também ofereceu bom resultado. A distância taxonômica de Gölz \& Reinhard, também usada por eles, é atrativa por sua simplicidade, tipo de informação que resulta e boa performance, apesar das falhas do ponto de vista teórico.

Van den Berg (1996) Utilizou análise de discriminantes canônicas, méłodos de agrupamento e análise filogenética para avaliar o padrão de variabilidade intra e interespecífica dentro do gênero Cattleya (Orchidaceae), levando também em consideração dados de florescimento destas espécies e dados biogeográficos. Concluiu que o gênero Cattleya apresenta padrões de variabilidade intra e interespecíficos que são bastante adequados à teoria dos refúgios florestais do Pleistoceno. De acordo com estes padrões, sugeriu quatro processos evolutivos de diversificação. Fez inferências filogenéticas, com base no cladograma construído e, como conclusões taxonômicas mostrou a necessidade de se esclarecer a nomenclatura infraespecífica de $C$. bicolor e detectou variação clinal entre C. granulosa e C. schofieldiana através de uma população intermediária, sugerindo que ambas as espécies chamem-se C. granulosa. Além disso, avaliou os sistemas de classificação existentes para o gênero Cattleya.

\section{3.) Refúgios do Pleistoceno}

Segundo Haffer (1987a) por muito tempo pensou-se que as flutuações climáticas dos últimos dois milhões de anos, período Quaternário, não afetaram muito as terras baixas tropicais. Porém, através de extensos estudos em diversas áreas do conhecimento, mostrou-se que apesar das flutuações de temperatura não serem muito 
grandes, a alternância de períodos climáticos secos e úmidos conduziu a grandes mudanças na distribuição das florestas e das savanas.

Os períodos glaciais (secos e frios) trouxeram, como conseqüência nas terras baixas tropicais, a redução da vegetação florestal e a expansão das savanas, estepes, das vegetações desérticas e das gramíneas. Por outro lado, nos períodos interglaciais a situação é inversa Durante a última glaciação (Wisconsin-Würm), a floresta tropical ficou restrita a áreas menores, denominadas refúgios do Pleistoceno (Haffer, 1987a).

As vegetações tropicais (florestais ou não) são antigas, originadas nos períodos Cretácio e Terciário. A ocorrência initerrupta de florestas e savanas resultou em condiçōes ecológicas estáveis para plantas e animais, explicando assim, a longa história de co-evolução e co-adaptação. Porém, devido a mudanças climáticas do Pleistoceno, toda a área de distribuição geográfica destas vegetações foi muito alterada, trazendo diferenciação orgânica específica e subespecífica (Haffer, 1987a).

Brown Jr. (1987a) apresenta um mapa baseado em evidências de vegetação, dados paleoclimáticos, pedológicos e geomorfológicos, mostrando áreas onde as florestas úmidas provavelmente persistiram durante a última glaciação.

Segundo Prance (1987) dados botânicos dão suporte à existência de áreas florestais com alto endemismo. Interpreta-se que estas áreas tenham permanecido estáveis durante períodos secos.

Este mesmo autor fez revisão de literatura, relatando a existência de oito refúgios no México e América Central, alto endemismo fortemente influenciado pela grande variabilidade de tipos 
de solo e habitats nas montanhas leste dos Andes e a presença de vinte e seis centros de endemismo nas florestas tropicais das terras baixas da América do Sul. Também é possível identificar centros de endemismo em unidades de floresta seca e em unidades isoladas de floresta tropical, como é o caso de brejos associados a pequenas montanhas na caatinga no Nordeste do Brasil.

Pouco se sabe sobre a especiação nos refúgios, mas acredita-se que isto foi uma causa importante da riqueza de espécies nas florestas tropicais, além dos outros modos de especiação reconhecidos. Porém, há necessidade de um número maior de trabalhos experimentais (Prance, 1987).

Este autor ainda refere-se à diferenciação em insetos $e$ pássaros, que é muito mais rápida do que em árvores, pois podem apresentar várias gerações em um ano, enquanto árvores, muitas vezes, demoram trinta anos para chegar à maturidade reprodutiva. Ele observa ainda que a maior parte das espécies de plantas estudadas por ele ou por outros autores há sempre pequena ocorrência de ocloespécies polimórficas. Estas espécies apresentam grande variação morfológica, sendo difícil classificar, em termos formais, quantas delas ocuparam os refúgios, havendo portanto necessidade de maior experimentação.

Segundo Brown Jr. (1987b) há grandes correlações entre os centros de endemismo de subespécies de borboletas dos grupos Heliconiine e Ithomiine e o modelo geocientífico da continuidade de vegetação florestal na glaciação Wisconsin-Würm, sendo que trinta e dois dos quarenta e quatro centros de endemismo coincidem com áreas de refúgios florestais e o restante ajusta-se razoavelmente a este 
modelo (exceto na llha do Marajó, que foi inundada). Embora correlações não sejam provas, o ajuste entre os padrões biogeográficos e o modelo geohistórico baseado em diferentes fontes de dados é uma indicação muito boa de que seja provável que este padrão de diferenciação observado nas subespécies de borboletas tenha sido resultante do modelo geocientífico em questão.

Segundo este autor padrões de diversidade específica são pouco correlacionados à micro-heterogeneidade ambiental no presente.

Segundo Haffer (1987b) com base nas mudanças climáticas e de vegetação ocorrida no Pleistoceno, que afetaram as terras baixas neotropicais, e na teoria de especiação alopátrica, pode-se predizer a ocorrência de alguns grupos de espécies e subespécies endêmicas bem definidas de plantas e animais em áreas de refúgios ecológicos durante períodos adversos. Ocorrência de zonas de contato secundárias entre taxa diferenciados com ou sem hibridação entre refúgios é esperada. Nestas regiões, assume-se que populações tenham estabelecido o contato após dispersarem-se de seus respectivos refúgios, quando ocorreram clima e vegetação favoráveis.

Este autor revisou os dados ornitogeográficos da região neotropical e constatou que estes corroboram esta teoria, pois grupos de espécies e subespécies endêmicas formam centros de endemismo em habitats superficialmente uniformes, com vasta floresta tropical de terras baixas da Amazônia e numerosas zonas híbridas, interpretadas como zonas de contato secundária, podem indicar a presença de barreiras ecológicas que desapareceram. 
Van den Berg (1996) verificou que a diferenciação orgânica no gênero Cattleya (Orchidaceae) adapta-se muito bem à teoria dos refúgios do Pleistoceno. 


\section{3.) MATERIAL E MÉTODOS}

3.1.) Material:

As espécies estudadas foram Miltonia anceps, M. clowesii, M. cuneata, M. flavescens, M. regnellii, M. russeliana, M. spectabilis e M. spectabilis var. moreliana. Destas espécies foram amostradas populações em várias localidades do Brasil e, particularmente no caso de $M$. flavescens, houve também uma população originária do Paraguai (Tabela 3). As plantas analisadas foram coletadas há pelo menos cinco anos atrás, por funcionários e pesquisadores do Departamento de Genética da ESALQ/USP e vêm sendo mantidas sob condições ambientais uniformes no orquidário deste departamento. Isto assegura que a variação observada entre estas plantas seja atribuída a diferenças de origem genética ou ao acaso.

TABELA 3. Espécies de Miltonia Ldl. (Orchidaceae) consideradas, suas respectivas populaçōes e o tamanho da amostra de cada população.

\begin{tabular}{|c|c|c|c|}
\hline Espécie & Populaçāo & Nome Reduzido & Tamanho da Amostra \\
\hline M. anceps & Poço Parado - RJ & ancl & 31 \\
\hline \multirow[t]{2}{*}{ M. clowesii } & Poço Parado - RJ & cll & 09 \\
\hline & Domingos Martins - ES & $\mathrm{cl} 2$ & 01 \\
\hline M. cuneata & Serra dos Órgãos - RJ & cunl & 37 \\
\hline \multirow[t]{4}{*}{ M. flovescens } & Paraguai & fil & 06 \\
\hline & Piracicaba - SP & $f 2$ & 18 \\
\hline & Petrópolis - RJ & $f(3)$ & 08 \\
\hline & Juçari - BA & fi4 & 40 \\
\hline
\end{tabular}


TABELA 3. Continuação.

\begin{tabular}{|c|c|c|c|}
\hline & Jacarei - SP & $f 15$ & 02 \\
\hline & Paraná & $\mathrm{fl} 6$ & 01 \\
\hline & Domingos Martins - ES & $\mathrm{fl} 7$ & 02 \\
\hline & Ibati - PR & fl8 & 01 \\
\hline & Entre Barão Jacutinga - SP & $\mathrm{fl9}$ & 04 \\
\hline & Vitória da Conquista - BA & filo & 01 \\
\hline & Serra da Fartura - SP & flll & 04 \\
\hline & Rui Barbosa - BA & f112 & 01 \\
\hline & Guaxupé & fll3 & 01 \\
\hline & Capivara - MG & fll 4 & 01 \\
\hline & Irai - RS & fil 5 & 02 \\
\hline \multirow{2}{*}{$\begin{array}{l}\text { M. spectabilis var. } \\
\text { moreliano }\end{array}$} & Canário - ES & spl & 12 \\
\hline & Juçari - BA & $\mathrm{sp} 2$ & 01 \\
\hline \multirow[t]{11}{*}{ M. regnellii } & Entre Est. De São Paulo e & rel & 29 \\
\hline & Norte do Paraná & & \\
\hline & Angra dos Reis - RJ & re2 & 14 \\
\hline & Vitória da Conquista - BA & re3 & 02 \\
\hline & Torres - RS & re4 & 01 \\
\hline & Litoral SUI - SP & re5 & 01 \\
\hline & Ubatuba - SP & re6 & 01 \\
\hline & Poços de Calda - MG & re7 & 02 \\
\hline & Curitiba (Serra) - PR & re8 & 03 \\
\hline & Congonhal - MG & re9 & 01 \\
\hline & Estiva - MG & relo & 01 \\
\hline \multirow[t]{4}{*}{ M. russeliana } & Paranaguá - PR & rul & 02 \\
\hline & Juquiá - SP & ru2 & 02 \\
\hline & Maresia - SP & ru3 & 02 \\
\hline & Juçari - BA & ru4 & 03 \\
\hline \multirow[t]{5}{*}{ M. spectabilis } & Toque-Toque Pequeno - SP & spl & 25 \\
\hline & Petrópolis - RJ & sp2 & 81 \\
\hline & Cascata - RJ & sp3 & 06 \\
\hline & Angra dos Reis - RJ & sp4 & 01 \\
\hline & Muqui - ES & sp5 & 03 \\
\hline Total & & & 363 \\
\hline
\end{tabular}

Estas mesmas pessoas fizeram herbários florais lou fichas florais) de cada uma das plantas amostradas, sendo que cada uma das flores dissecadas deu origem a uma destas fichas. Cada ficha floral 
recebeu um número (correspondente ao número da planta) e nela foram anotadas a identificação da espécie, a procedência e a data de florescimento correspondentes. Também, a partir de cada ficha floral tomaram as seguintes medidas: maior comprimento da sépala dorsal, da sépala lateral, da pétala e do labelo; maior largura da sépala dorsal, da sépala lateral, da pétala e do labelo; comprimento do pedúnculo, do ovário e da coluna e largura e espessura da coluna. Todas estas medidas foram feitas através de régua milimetrada.

Estas fichas florais serviram como fonte de dados para este trabalho, uma vez que parte das plantas analisadas morreu, inviabilizando, portanto, a tomada de medidas vegetativas e a análise de outras flores. Através do uso de paquímetro, foram tomadas dezenove medidas adicionais, visando melhor representação morfológica das peças florais. Os novos caracteres medidos foram: largura do labelo, das sépalas dorsal e lateral a cada $20 \%$ do comprimento; comprimento do labelo a cada $25 \%$ da largura. Assim, trinta e dois caracteres foram analisados (Tabela 4 e Figura 2). Foi considerada apenas uma destas fichas por planta analisada.

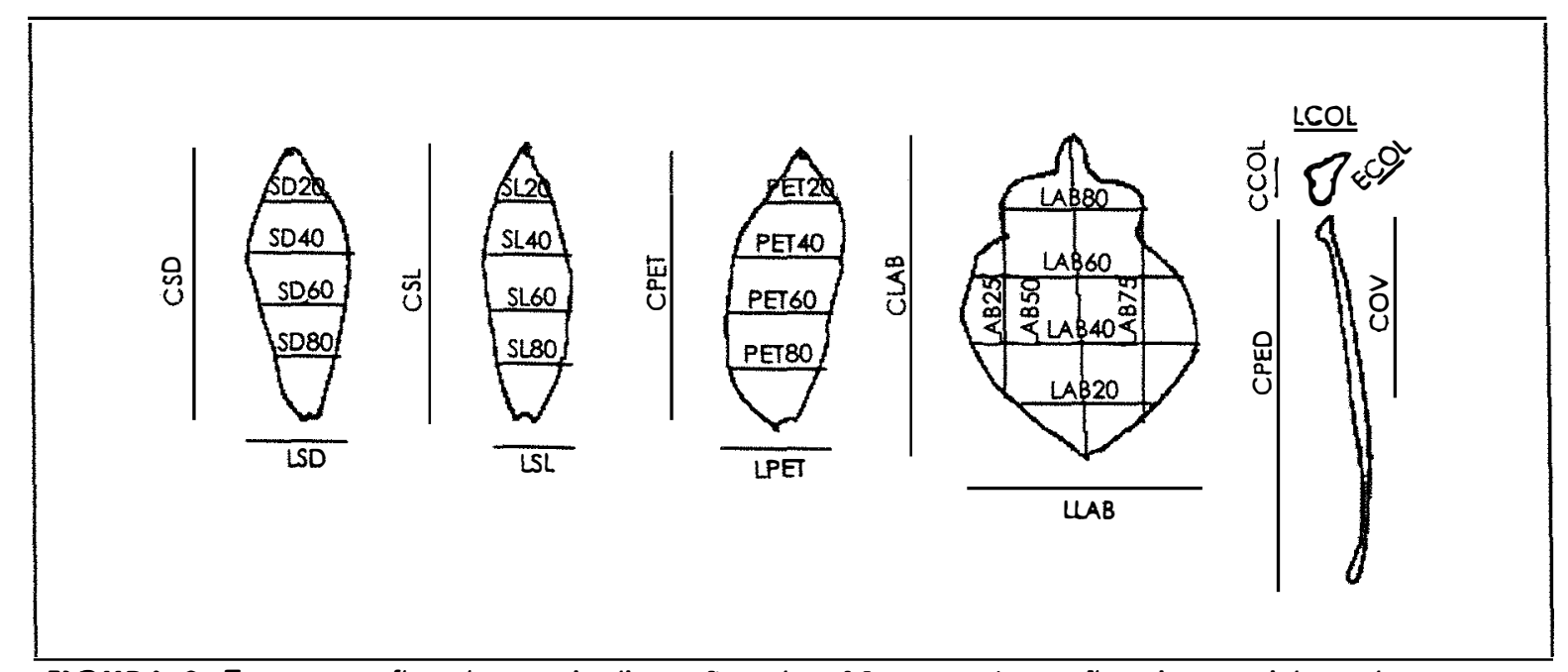

FIGURA 2. Esquema floral com indicação dos 32 caracteres florais considerados 
TABELA 4. Lista dos 32 caracteres florais considerados em Miltonia Ldl. (Orchidaceae) e siglas correspondentes.

\begin{tabular}{|c|c|}
\hline Sigla do Caráter & Nome do Caráter \\
\hline CSD & maior comprimento da sépala dorsal \\
\hline LSD & maior largura da sépala dorsal \\
\hline CSL & maior comprimento da sépala lateral \\
\hline LSL & maior largura da sépala lateral \\
\hline CPET & maior comprimento da pétala \\
\hline LPET & maiorlargura da pétala \\
\hline CPED & comprimento do pedúnculo \\
\hline CLAB & maior comprimento do labelo \\
\hline LLAB & maior largura do labelo \\
\hline cov & comprimento do ovário \\
\hline CCOL & comprimento da coluna \\
\hline LCOL & largura da coluna \\
\hline ECOL & espessura da coluna \\
\hline$\angle A B 20$ & largura do labelo a $20 \%$ do comprimento \\
\hline$L A B 40$ & largura do labelo a $40 \%$ do comprimento \\
\hline$\angle A B 60$ & largura do labelo a $60 \%$ do comprimento \\
\hline LAB80 & largura do labelo a $80 \%$ do comprimento \\
\hline SD2O & largura da sépala dorsal a $20 \%$ do comprimento \\
\hline SD40 & largura da sépala dorsal a $40 \%$ do comprimento \\
\hline SD60 & largura da sépala dorsal a $60 \%$ do comprimento \\
\hline SD80 & largura da sépala dorsal a $80 \%$ do comprimento \\
\hline SL2O & largura da sépala lateral a $20 \%$ do comprimento \\
\hline SL40 & largura da sépala lateral a $40 \%$ do comprimento \\
\hline SL60 & largura da sépala lateral a $60 \%$ do comprimento \\
\hline SL80 & largura da sépala lateral a $80 \%$ do comprimento \\
\hline PET2O & largura da pétala a $20 \%$ do comprimento \\
\hline PET40 & largura da pétala a $40 \%$ do comprimento \\
\hline PET60 & largura da pétala a $60 \%$ do comprimento \\
\hline PET8O & largura da pétala a $80 \%$ do comprimento \\
\hline LAB25 & largura do labelo a $25 \%$ do comprimento \\
\hline LAB50 & largura do labelo a $50 \%$ do comprimento \\
\hline LAB75 & largura do labelo a $75 \%$ do comprimento \\
\hline
\end{tabular}

Embora Sneath \& Sokal (1973) determinem que o número mínimo de variáveis deva estar entre quarenta e sessenta, muitas vezes o material com que se trabalha não permite encontrar número tão 
grande de variáveis a serem analisadas. Adicionalmente, muitos autores têm utilizado, com sucesso, número menor de variáveis (Baum et al., 1995; Astholm \& Nyman, 1994; Baum \& Bailey, 1991; Small \& Fawzi, 1992; Brieger et al., 1963; Dupuy et al., 1985; Dufrêne et al., 1991; Ferrari \& Hunziker, 1986).

As plantas consideradas neste estudo que pertençam a localidades de uma mesma região geográfica, ou seja, de locais que apresentem mesmas características ambientais e ecológicas, foram agrupadas em uma única população. No caso de M. anceps, temos uma única população, pois todas as plantas foram amostradas no mesmo local (Poço Parado, RJ). O mesmo ocorre em M. cuneata, sendo que todas as plantas foram coletadas na Serra dos Órgãos - RJ. No caso de M. clowesii, as plantas coletadas em Poço Parado - RJ, na Mantiqueira entre Rio de Janeiro e Petrópolis - RJ e Granja Fundação Getúlio Vargas (Nova Friburgo - RJ) foram agrupadas numa mesma população. Para a espécie M. flavescens temos várias populações: a) Paraguai; b) Piracicaba - SP, que reúne plantas das localidades Piracicaba e Barreiro Rico; c) Petrópolis, que reúne os indivíduos coletados em Mantiqueira entre Rio de Janeiro e Petrópolis - RJ e na Granja Fundação Getúlio Vargas (Nova Friburgo - RJ); d) Juçari - BA, que reúne as localidades bahianas de Juçari, Fazenda Indaiá, Guandu, Cacaual e Fazenda Marineda. No caso de M. spectabilis var. moreliana, tem-se somente uma população, Canário - ES. Para a espécie M. regnellii, há duas populações: a) São Paulo e Norte do Paraná, que agrupa, no Estado de São Paulo, as localidades de são Capão Bonito, regiāo entre Apiaí e Iporanga e Fazenda Paulista em Pilares do Sul, e no norte do Paraná, a localidade Ibaiti; b) Angra dos Reis - RJ. M. spectabilis 
apresenta três populações: a) Toque-Toque Pequeno - SP; b) Petrópolis RJ, que engloba as localidades de Petrópolis e seus arredores incluindo bairro Bom Jardim e Mantiqueira entre Rio de Janeiro - RJ e Petrópolis; c) Cascata - RJ. A espécie M. russeliana apresenta quatro locais diferentes de coleta (área entre Paranaguá - PR, Juquiá - SP, Maresia - SP e Juçari BA), porém não é possível fazer análise inter-populacional dentro desta espécie, pois o número de indivíduos amostrados por populaçāo é muito baixo, variando de dois a três (Tabela 3 ).

As espécies M. clowesii, M. flavescens, M. regnellii, $M$. spectabilis e M. spectabilis var. moreliana apresentam plantas coletadas também em outras localidades, diferentes das descritas acima. Mas, como o número de indivíduos representantes destes outros locais é muito pequeno, não foram incluídos nas análises intraespecíficas. Porém, nas análises interespecíficas puderam ser considerados, contribuindo para melhorar a representatividade destas espécies (Tabela 3).

Foram feitas análises interpopulacionais dentro das espécies M. flavescens, M. regnellii e M. spectabilis, considerando somente as populações com tamanho amostral maior ou igual a seis (Tabela 5). 
TABELA 5. Populaçōes utilizadas nas análises intraespecíficas em Miltonia Ldl. (Orchidaceae).

\begin{tabular}{|c|c|c|c|}
\hline Espécie & Populaçāo & Nome Reduzido & Tamanho da Amostra \\
\hline \multirow[t]{4}{*}{ M. flavescens } & Paraguai & fll & 06 \\
\hline & Piracicaba - SP & $\mathrm{fl} 2$ & 18 \\
\hline & Juçari - BA & $\mathrm{fl} 3$ & 40 \\
\hline & Petrópolis - RJ & flu & 08 \\
\hline \multirow[t]{3}{*}{ M. regnellii } & Entre Est. De São Paulo e & rel & 29 \\
\hline & Norte do Paraná & & \\
\hline & Angra dos Reis - RJ & re2 & 14 \\
\hline \multirow[t]{3}{*}{ M. spectabilis } & Toque-Toque Pequeno - SP & spl & 25 \\
\hline & Petrópolis - RJ & $\mathrm{sp} 2$ & 81 \\
\hline & Cascata-RJ & $\mathrm{sp} 3$ & 06 \\
\hline Total & & & 227 \\
\hline
\end{tabular}

3.2.) Métodos:

O material mencionado na Tabela 3 foi analisado através de análise de variância para cada caráter isoladamente e através de análise de correlação para cada par de caracteres. Estas análises foram feitas entre os oito taxa considerados. Na análise entre grupos taxonômicos, para melhor representatividade dos taxa, foi considerado todo o material disponível, incluindo aqueles de localidades representadas, às vezes, por uma única planta. Os resultados da análise de correlação entre caracteres entre taxa são importantes, pois sendo as correlações significativas, justifica-se ainda mais $\circ$ uso de análises multivariadas.

As análises multivariadas foram utilizadas em dois níveis: entre os oito taxa avaliados e dentro de cada taxon, que possuísse mais de uma população, cujo tamanho fosse maior ou igual a seis indivíduos. Trata-se de um modelo matemático hierárquico incompleto. Entre 
grupos taxonômicos, como dito acima, foram analisados todos os indivíduos disponíveis, visando melhor representação de cada taxon. Porém, na análise dentro de espécies (entre populações) foram excluídas populações de tamanho menor que seis indivíduos, pois a representatividade destas estaria prejudicada.

Foram calculadas as distâncias morfológicas, no caso a Distância Generalizada de Mahalanobis $\left(D^{2}\right)$, entre todos os pares de grupos taxonômicos e também a estatística $F$ para cada uma destas distâncias para avaliar seu nível de significância. Esta distância foi escolhida por apresentar como vantagens o fato de considerar a variação intraespecífica e as correlações entre as variáveis. Com base nestas distâncias, foram formados os fenogramas entre espécies e, dentro de espécie, entre populações. Foram utilizados dois métodos de agrupamento aglomerativos: UPGMA (método das ligações médias não ponderadas), utilizado praticamente por todos os autores atuais, sendo, portanto útil na comparação entre resultados obtidos por diferentes autores; método de ligação simples (vizinho mais próximo), que além de ser bastante difundido na literatura, permite detectar variação clinal entre grupos.

A análise discriminante canônica foi utilizada por considerar as correlações residuais existentes entre as médias das OTU's, o que se traduz numa vantagem em relação aos componentes principais. $\mathrm{Na}$ análise de variáveis canônicas, o princípio de conglomeração baseia-se na distância de Mahalanobis. Outra vantagem do método, já discutida anteriormente, é que mesmo que as pressuposições para que ele seja usado não sejam encontradas, seu uso de maneira exploratória é 
permitido. As funções discriminantes foram usadas para fornecer comparação entre a classificação obtida e a preestabelecida.

Foram também considerados dados biogeográficos e de época e intensidade de florescimento. Os dados fenológicos, porém, foram utilizados somente de forma gráfica, por se tratarem de dados circulares e por serem muitos desbalanceados, o que dificulta muito a análise estatística.

Com exceção dos fenogramas, que foram construídos através do programa STATISTICA for Windows (StatSsoft, 1993), todas as análises estatísticas foram feitas através do programa SAS for Windows (SAS Institute Inc., 1992). Para tanto, a consulta dos manuais do SAS (SAS Institute Inc., 1994; 1995a; 1995b) foi indispensável. Os gráficos de época e intensidade de florescimento foram feitos através do programa Excel for Windows 95 (Microsoft, 1995), enquanto que os gráficos das análises discriminantes canônicas foram feitos através do programa Origin (Microcal Software, 1994), com exceção dos gráficos do tipo "dot" (entre populações de Miltonia regnelli e entre Miltonia spectabilis e M. spectabilis var. moreliana), os quais foram feitos através do programa SYSTAT (SYSTAT, Inc., 1992). 


\section{4.) RESULTADOS E DISCUSSÃO:}

\section{1.) Entre espécies}

Para a análise entre espécies foram considerados todos os indivíduos disponíveis citados no item 3.1 ., mesmo quando havia apenas um indivíduo num dado local, pois a retirada destes indivíduos não melhoraria a análise e além disto, pioraria a representação de cada grupo taxonômico. No caso das análises entre $M$. spectabilis e $M$. spectabilis var. moreliana, o mesmo procedimento foi adotado.

\subsection{1.) Entre todas as espécies analisadas}

\subsubsection{1.) Análises de variância por caráter}

Os oito grupos taxonômicos estudados mostraram diferenças significativas entre si, a $0,01 \%$ de probabilidade, para cada um dos trinta e dois caracteres morfológicos estudados (Tabela 6). 0 teste $F$ indicou alta diversidade entre os taxa. Este resultado é concordante com a taxonomia tradicional, uma vez que os grupos considerados foram estabelecidos por ela. Sendo os resultados significativos para todos os caracteres, isto é uma indicação de que todos eles devam ser considerados, justificando mais uma vez a análise multivariada. 
TABELA 6. Médias, desvios-padrōes, coeficientes de variaçāo, teste F e probabilidades de $\mathrm{F}$ para os 32 caracteres morfológicos estudados entre espécies de Miltonia Ldl. (Orchidaceae).

\begin{tabular}{|c|c|c|c|c|c|}
\hline Caráter & Média & Desvio-padrõo & C.V. & $F$ & $\begin{array}{c}\text { Probabilidade } \\
\text { de } F\end{array}$ \\
\hline CDS & 36.20 & 4.60 & 12.62 & 75.56 & $<0.0001$ \\
\hline LSD & 10.01 & 1.50 & 15.00 & 140.00 & $<0.0001$ \\
\hline CLS & 37.51 & 4.58 & 12.20 & 82.60 & $<0.0001$ \\
\hline LSL & 9.37 & 1.46 & 15.54 & 205.37 & $<0.0001$ \\
\hline CPET & 33.54 & 3.92 & 11.68 & 63.90 & $<0.0001$ \\
\hline LPET & 10.55 & 1.50 & 14.24 & 209.20 & $<0.0001$ \\
\hline CPED & 40.58 & 5.46 & 13.46 & 184.86 & $<0.0001$ \\
\hline CLAB & 36.44 & 4.06 & 11.14 & 176.34 & $<0.0001$ \\
\hline LLAB & 24.34 & 3.77 & 15.48 & 364.90 & $<0.0001$ \\
\hline COVA & 20.60 & 3.65 & 17.72 & 223.33 & $<0.0001$ \\
\hline $\mathrm{CCOL}$ & 9.56 & 1.16 & 12.18 & 244.61 & $<0.0001$ \\
\hline LCOL & 5.91 & 0.97 & 16.47 & 75.70 & $<0.0001$ \\
\hline ECOL & 6.15 & 1.02 & 16.59 & 66.42 & $<0.0001$ \\
\hline LAB2O & 19.61 & 3.05 & 15.56 & 463.58 & $<0.0001$ \\
\hline LAB40 & 23.51 & 3.85 & 16.37 & 366.71 & $<0.0001$ \\
\hline$\angle A B 60$ & 17.96 & 3.95 & 22.00 & 301.91 & $<0.0001$ \\
\hline LAB80 & 14.21 & 2.38 & 16.76 & 219.54 & $<0.0001$ \\
\hline SD2O & 6.41 & 1.31 & 20.52 & 148.86 & $<0.0001$ \\
\hline SD40 & 9.09 & 1.41 & 15.49 & 162.65 & $<0.0001$ \\
\hline SD60 & 8.95 & 1.29 & 14.40 & 114.39 & $<0.0001$ \\
\hline SD80 & 6.74 & 1.06 & 15.72 & 103.12 & $<0.0001$ \\
\hline SL2O & 6.06 & 1.17 & 19.36 & 188.25 & $<0.0001$ \\
\hline SL40 & 8.54 & 1.38 & 16.13 & 231.50 & $<0.0001$ \\
\hline SL60 & 8.07 & 1.21 & 15.02 & 164.17 & $<0.0001$ \\
\hline SL8O & 6.07 & 0.96 & 15.82 & 105.76 & $<0.0001$ \\
\hline PET2O & 6.73 & 1.26 & 16.68 & 158.42 & $<0.0001$ \\
\hline PET40 & 9.50 & 1.42 & 14.91 & 240.57 & $<0.0001$ \\
\hline PET6O & 9.77 & 1.36 & 13.95 & 207.17 & $<0.0001$ \\
\hline PET8O & 8.65 & 1.21 & 13.97 & 206.04 & $<0.0001$ \\
\hline LAB25 & 26.69 & 3.11 & 11.67 & 175.80 & $<0.0001$ \\
\hline LAB50 & 35.65 & 4.09 & 11.48 & 191.83 & $<0.0001$ \\
\hline LAB75 & 26.69 & 3.04 & 11.41 & 188.08 & $<0.0001$ \\
\hline
\end{tabular}




\subsubsection{2.) Análise de correlação entre caracteres}

Excetuando a diagonal principal da matriz de correlações, 97,8\% de todas as possiveis correlações entre pares de caracteres entre taxa foram significativas a $0,1 \%$ de probabilidade de erro do tipo 1 (APÊNDICE 1). Este fato é uma justificativa para $\circ$ uso de análise multivariada. A presença de altas correlações entre os caracteres também justifica o uso da Distância Generalizada de Mahalanobis (D2), que as desconta, sendo portanto vantajosa em relação às distâncias Euclideana e Euclideana Média.

\subsubsection{3.) Distância generalizada de Mahalanobis (D2)}

Distâncias Generalizadas de Mahalanobis entre cada par de taxa considerado estão apresentadas na (Tabela 7). A estatística $F$ para cada distância foi significativa a $0,01 \%$ de probabilidade de erro tipo I.

TABELA 7. Distâncias generalizadas de Mahalanobis entre espécies de Miltonia Lal. (Orchidaceae).

\begin{tabular}{lrrrrrrrr}
\hline Espécies & \multicolumn{1}{c}{ M. anc. } & M. clo. & M. cun. & M. flo. & M.sp.mor & M. reg. & M. rus. & M.spe. \\
\hline M. onc. & 0 & & & & & & & \\
M. clo.. & 84.323 & 0 & & & & & & \\
M. cun. & 104.303 & 152,564 & 0 & & & & & \\
M. flo & 98.448 & 118,011 & 224,981 & 0 & & & \\
M.sp.mor & 259.014 & 227,857 & 229,085 & 333,129 & 0 & & \\
M. reg. & 90.158 & 52,599 & 152,396 & 114,866 & 172,015 & 0 & & \\
M. rus. & 91.022 & 138,761 & 140,521 & 105,785 & 259,431 & 129,663 & 0 & \\
M.spe.. & 66.801 & 111,320 & 167,098 & 100,262 & 141,394 & 81,582 & 99,947 & 0 \\
\hline
\end{tabular}


Aqui é necessário chamar a atenção para o fato do desbalanceamento do número de individuos entre as espécies e entre populações dentro de espécies, quando há mais de uma população. A precisão das médias entre cada taxon é diferente. Como o número de indivíduos por população dentro de espécie é diferente, a média por espécie é tendenciosa para locais com maior número de indivíduos. As conclusões não podem ser generalizadas, mas restritas aos locais de amostragem, principalmente aos locais com maior tamanho populacional. Para evitar este problema de desbalanceamento, poderse-iam descartar parte dos dados. Mas isto não foi feito para que não houvesse perda de informações. Além disso, haveria diminuição na precisão das médias das populações e espécies que sofressem redução no número de indivíduos. Apesar destas restrições, muitos autores têm usado as análises multivariadas de forma exploratória, por elas serem bastante robustas e resultarem em conclusões que estão de acordo com os aspectos biológicos dos organismos estudados. Rao (1952) utilizou-se de dados desbalanceados para explicar a distância de Mahalanobis. Morrison (1976), Chatfield \& Collins (1980), Manly, (1995) discutem a possibilidade de se utilizarem técnicas multivariadas de forma exploratória e com sucesso. Trabalhos como os de DuPuy et al. (1984), Dufrêne et al. (1991), são exemplos disto.

Pelo que se vê na Tabela 7 , as espécies mais próximas $\left(D^{2}=52,597\right)$ são $M$. clowesii e $M$. regnellii, o que está de acordo com Pabst \& Dungs (1977), que colocaram ambas as espécies na mesma aliança. Além disto, ao observarmos suas flores, vemos que elas são semelhantes em alguns aspectos, como por exemplo o tamanho e a 
presença de manchas coloridas. Por outro lado, as espécies mais distantes são $M$. spectabilis var. moreliana e M. flavescens $\left(D^{2}=333,126\right)$.

Era esperado que $M$. spectabilis var. moreliana e $M$. spectabilis var. spectabilis apresentassem a menor distância entre os taxa considerados, por serem consideradas variedades de uma mesma espécie. Embora esta distância não seja tão pequena quando comparada a distâncias entre outras espécies estudadas, também não é a menor. Este fato pode ser mais um indicativo de que $M$. spectabilis var. moreliana deva ser elevada ao nível de espécie, como sugeriu Martins (1967) e Warner (citado por MCQueen \& MCQueen, 1993). Ainda considerando esta variedade, vemos que ela se distingue por apresentar maiores distâncias, em geral, em relação às demais espécies estudadas e que o taxon ao qual ela mais se aproxima é M. spectabilis, como esperado. Estas considerações parecem conflitantes, mas o que pode ser concluído é que apesar de M. spectabilis var. moreliana estar mais próxima taxonomicamente de $M$. spectabilis, a distância entre elas $\left(D^{2}=141,394\right)$ sugere que $M$. spectabilis var. moreliana seja elevada ao nível de espécie, não sendo mais considerada uma variedade de $M$. spectabilis.

\subsubsection{4.) Análise discriminantes canônica (CDA)}

O conjunto de dados não apresenta multinormalidade, amostragem aleatória e nem número de OTU's dentro de cada grupo superior ao número de caracteres estudados. Embora estas premissas exigidas pela técnica de CDA não tenham sido cumpridas, esta análise 
foi utilizada de forma exploratória, o que é bastante comum na literatura, como já exposto anteriormente.

Foram consideradas todas as variáveis discriminantes canônicas obtidas, pois são poucas e porque cada uma delas foi responsável pela discriminação de uma das espécies, com exceção do eixo canônico 6 (Figuras 3 a 10). A Tabela 8 mostra os autovalores e as proporção da variância total representada por cada variável discriminante canônica.

TABELA 8. Variáveis canônicas entre espécies de Miltonia Lal. (Orchidaceae), seus autovalores, diferenças entre estes autovalores, proporção da variância total representada por cada variável canônica e proporção cumulativa da variância com o acréscimo de sucessivas de variáveis canônicas.

\begin{tabular}{ccccc}
\hline Variável & Autovalor & Diferença & Proporção & Cumulativo \\
\hline Can1 & 20,4963 & 7,0222 & 0,4090 & 0,4090 \\
Can2 & 13,4742 & 5.1411 & 0,2689 & 0,6778 \\
Can3 & 8,3330 & 4,2497 & 0,1663 & 0,8441 \\
Can4 & 4,0833 & 2,6177 & 0,0815 & 0,9256 \\
Can5 & 1,4657 & 0,1242 & 0,0292 & 0,9548 \\
Can6 & 1,3415 & 0,4181 & 0,0268 & 0,9816 \\
Can7 & 0.9234 & - & 0,0184 & 1,0000 \\
\hline
\end{tabular}

Esta análise tem como passo intermediário o cálculo das Distâncias Generalizadas de Mahalanobis entre grupos e, como mencionado anteriormente, todos os grupos se separam entre si com probabilidade de $0,01 \%$ de erro do tipo 1 .

A partir dos resultados obtidos, observa-se que o primeiro eixo canônico (Canl) separa as espécies em quatro grupos (Figura 3). Partindo da esquerda para a direita em relação a Can I, o primeiro grupo é constituído apenas por $M$. flavescens, que difere das demais espécies, tanto em aspectos florais como nos aspectos vegetativos, 
embora seja colocada junto com $M$. spectabilis e $M$. anceps numa mesma aliança por Pabst \& Dungs (1977). As principais variáveis responsáveis por esta separação são CSD e CSL (negativamente relacionadas a este eixo) e CCOL e LAB20 (positivamente relacionadas a este eixo) (Figura 4). O segundo grupo reúne M. anceps, M. clowesii, M. regnellii, M. russeliana e $M$. spectabilis. O terceiro grupo é formado por M. cuneata e o quarto é formado por M. spectabilis var. moreliana. Há certa sobreposição entre os grupos 3 e 4, o que pode ser atribuído em parte à forma arredondada do labelo de $M$. spectabilis var. moreliana e de $M$. cuneata e à semelhança no tamanho de alguns indivíduos destes dois taxa, além de grande comprimento de coluna, grande largura da extremidade externa do labelo e pequeno comprimento das sépalas (Figura 4).

O segundo eixo canônico Can2 separa as espécies em três grupos (Figura 3). Considerando o eixo de sua parte inferior para cima temos o primeiro grupo formado por $M$. cuneata, o segundo por $M$. flavescens, M. anceps, M. clowesii, M. regnellii, M. russeliana e o terceiro grupo formado por M. spectabilis e M. spectabilis var. moreliana. Mais uma vez, M. cuneata distingue-se das demais espécies, sendo LAB80, PET80, CPED, LAB25, COV, CCOL, entre outras, as principais variáveis responsáveis por isso (Figura 4). M. spectabilis e M. spectabilis var. moreliana encontram-se no mesmo grupo, devido às suas semelhanças morfológicas e proximidade taxonômica, em concordância com a taxonomia tradicional.

O terceiro eixo canônico Can3 não separa muito bem as espécies, mas podemos observar que, à esquerda em relação a Can3, há a formação de um grupo constituído por $M$. regnellii, apesar da 
sobreposição de alguns indivíduos das espécies $M$. clowesii e $M$. spectabilis var. moreliana (Figura 5). M. regnellii apresenta maior largura da extremidade interna do labelo (LAB80) e largura e espessura da coluna menores (Figura 6). Há também a formação de um grupo à esquerda deste eixo, formado por $M$. spectabilis var. moreliana. A este grupo se sobrepõem alguns indivíduos de $M$. regnellii, M. clowesii, $M$. flavescens e M. spectabilis. Novamente, as variáveis LAB80, ECOL e LCOL têm grande influência nesta separação (Figura 6). O terceiro grupo localizado à direita em relação a Can3 é formado por $M$. anceps, $M$. cuneata, M. russeliana, M. spectabilis e por indivíduos de M. flavescens, que, em geral, apresentam peças florais mais estreitas largura e espessura de coluna maiores (Figura 6).

O quarto eixo canônico (Can4) separa as espécies em três grupos (Figura 5). Partindo da parte superior deste eixo, temos o primeiro grupo formado exclusivamente por $M$. anceps, caracterizada por apresentar coluna longa e comprimento de sépalas lateral e dorsal menores (Figura 6). O terceiro, formado por M. spectabilis var. moreliana, é determinado principalmente pelas variáveis CSL, CSD e CCOL (Figura 6). O grupo intermediário é constituído pelas demais espécies.

O eixo canônico 5 (Can5) separa as espécies em dois grupos (Figura 7). Partindo da esquerda em relação a este eixo, temos o primeiro grupo formado somente por indivíduos da espécie M. russeliana, enquanto que o outro grupo é formado pelas espécies restantes, constituídas por plantas cujas peças florais são mais longas e estreitas (Figuras 7 e 8). O eixo canônico 6 (Can6) não separa nitidamente nenhum grupo (Figura 7). Porém, M. russeliana, M. clowesii, M. spectabilis 
var. moreliana e $M$. anceps apresentam extremidade interna da sépala dorsal mais longa e menor largura de espessura de coluna (Figura 8).

O sétimo e último eixo canônico (Can7) mostra dois grupos de espécies. O primeiro, na parte superior da figura, formado por $M$. clowesii e o segundo constituído pelas demais espécies (Figura 9). As principais variáveis responsáveis por esta separação são LAB25, LAB75, PET80 e COV (Figura 10).

É importante observar que cada taxon foi isolado dos demais por pelo menos um eixo canônico, em concordância com a taxonomia tradicional. Assim, o eixo 1 (Canl) isola em três diferentes grupos M. cuneata, M. flavescens e M. spectabilis var. moreliana. O eixo 2 (Can2) isola $M$. cuneata, enquanto que o eixo 3 (Can3) isola $M$. regnellii. $O$ eixo 4 (Can4) isola em dois grupos distintos $M$. anceps e $M$. spectabilis var. moreliana. O eixo 5 (Can5) isola M. russeliana e Can7 isola M. clowesii. Somente M. spectabilis não se separa nitidamente das demais espécies (Figuras 3 a 10). Isto pode ser atribuído à maior variabilidade genética presente dentro desta espécie, possivelmente resultante de grande número de indivíduos amostrados em comparação às demais espécies.

Considerando apenas $M$. spectabilis e M. spectabilis var. moreliana, vemos que elas se sobrepōem de acordo com Can5 e que Can2 coloca as mesmas num único grupo, isolando-as das demais espécies. Embora estes fatos indiquem proximidade taxonômica entre estes taxa, eles apresentam-se isolados pelos eixos canônicos 1, 3, e 4. Apesar da sobreposição, estes taxa não se concentram na mesma região em relação ao eixo 7 . Com base nestes resultados (Figuras 3 a 
10), novamente se propõe que $M$. spectabilis var. moreliana seja elevada ao nivel de espécie, como proposto por Martins (1967).

É interessante notar que espécies endêmicas localizam-se em áreas de refúgios do Pleistoceno, como é o caso das plantas de $M$. anceps, M. clowesii, M. cuneata e M. spectabilis var. moreliana (Tabela 3).

A análise de funções discriminantes indicou que houve $100 \%$ de acerto na classificação prévia dos indivíduos nos taxa envolvidos. 


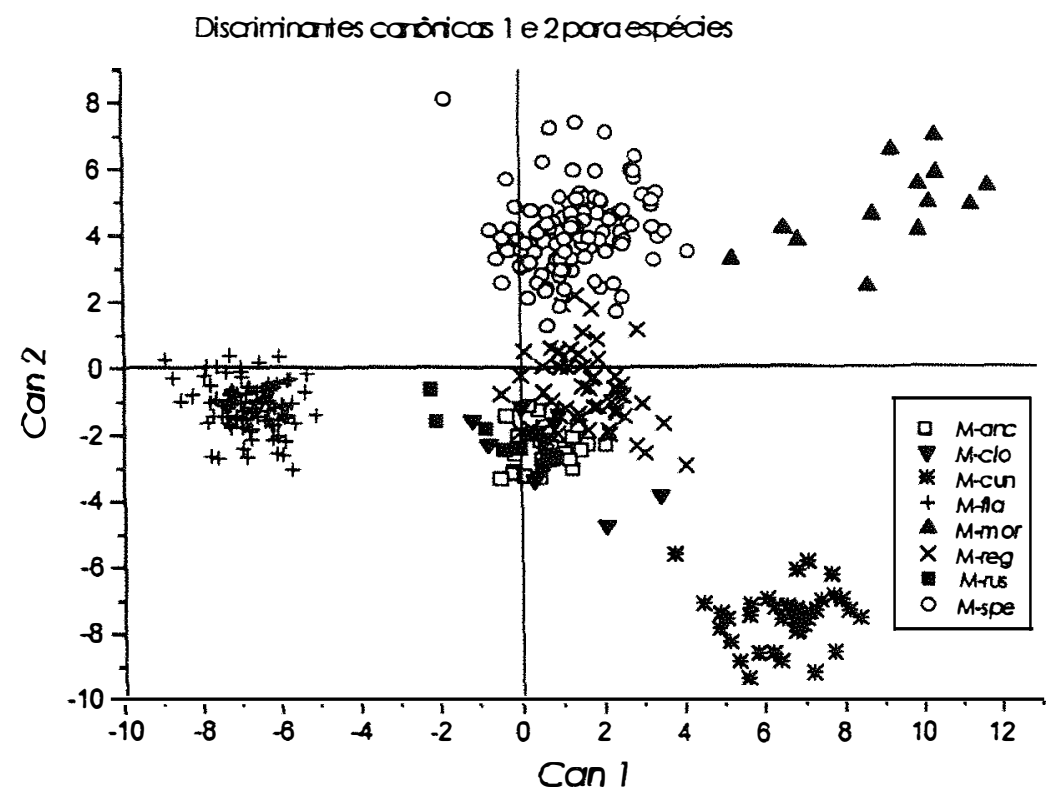

FIGURA 3. Escores provenientes da análise discriminante canônica entre espécies de Miltonia Ldl. (Orchidaceae), considerando Can 1 e Can2.

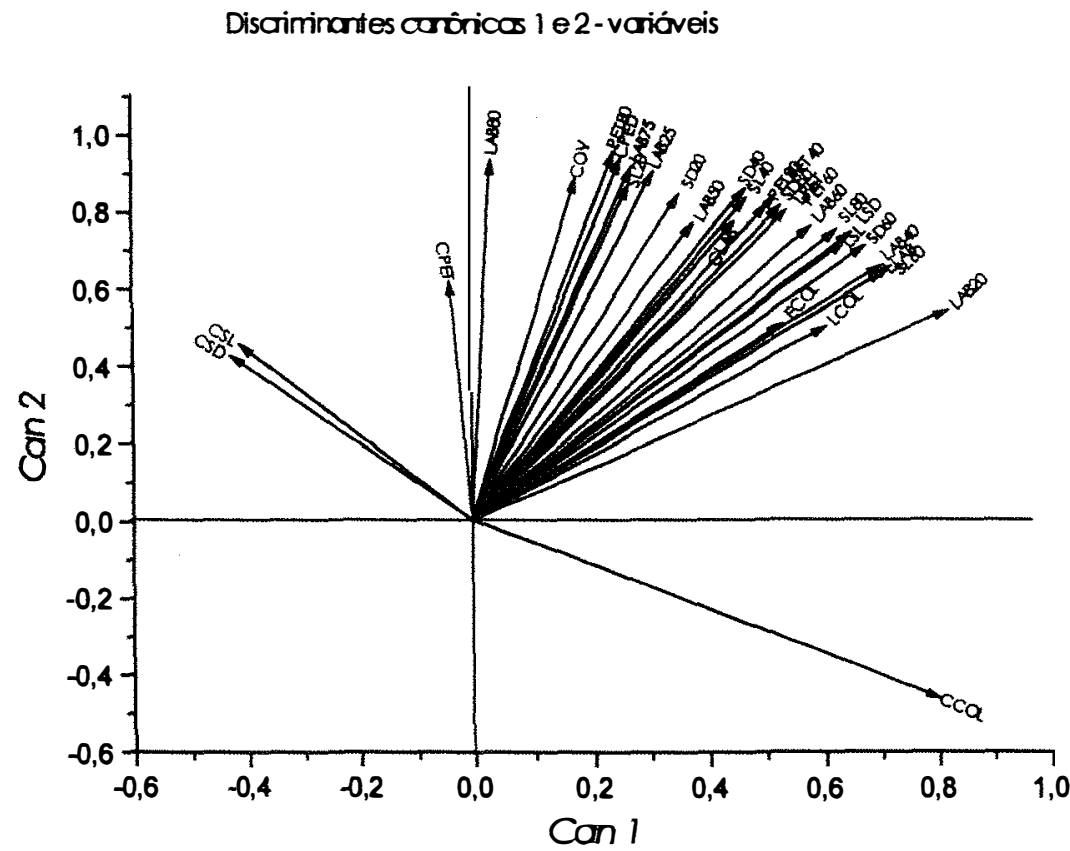

FIGURA 4. Contribuiçāo das variáveis originais para os eixos canônicos 1 e 2 entre espécies de Miltonia Ldl. (Orchidaceae), utilizando coeficientes estandardizados. 


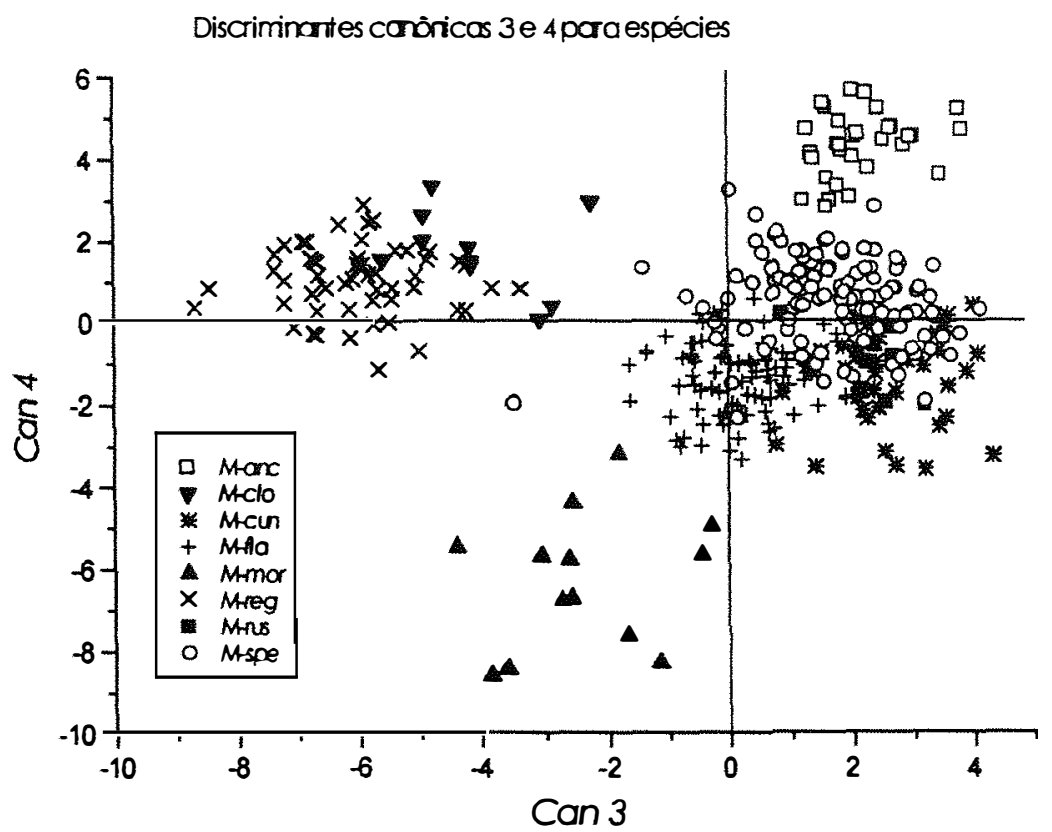

FIGURA 5. Escores provenientes da análise discriminante canônica entre espécies de Miltonia Ldl. (Orchidaceae), considerando Can3 e Can4.

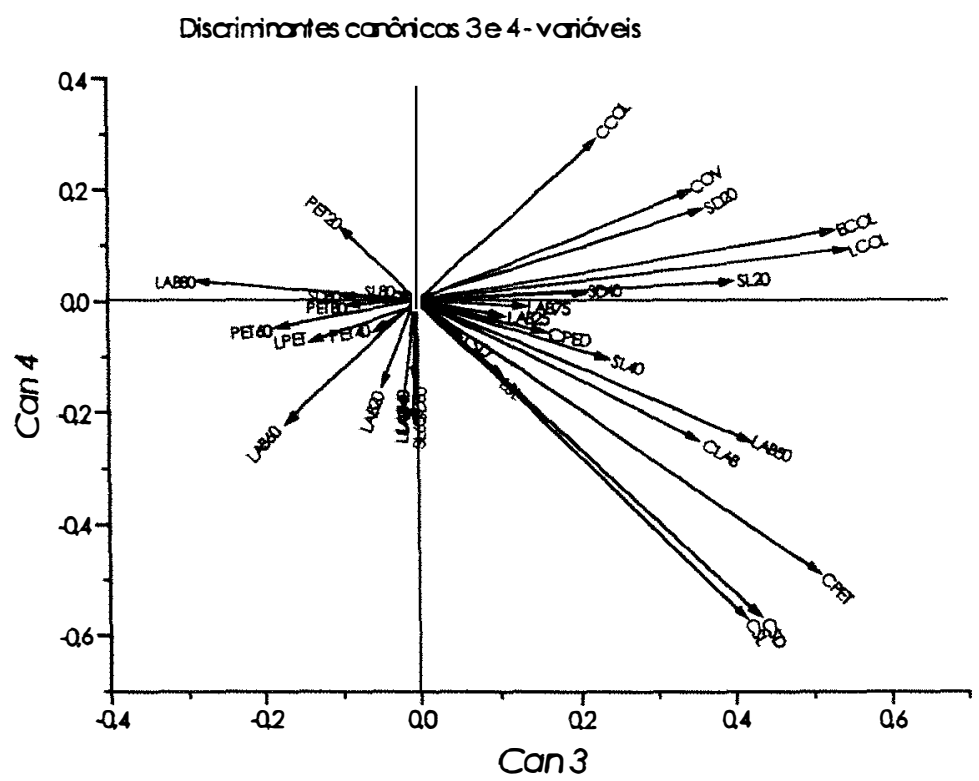

FIGURA 6. Contribuiçāo das variáveis originais para os eixos canônicos 3 e 4 entre espécies de Miltonia Ldl. (Orchidaceae), utilizando coeficientes estandardizados. 


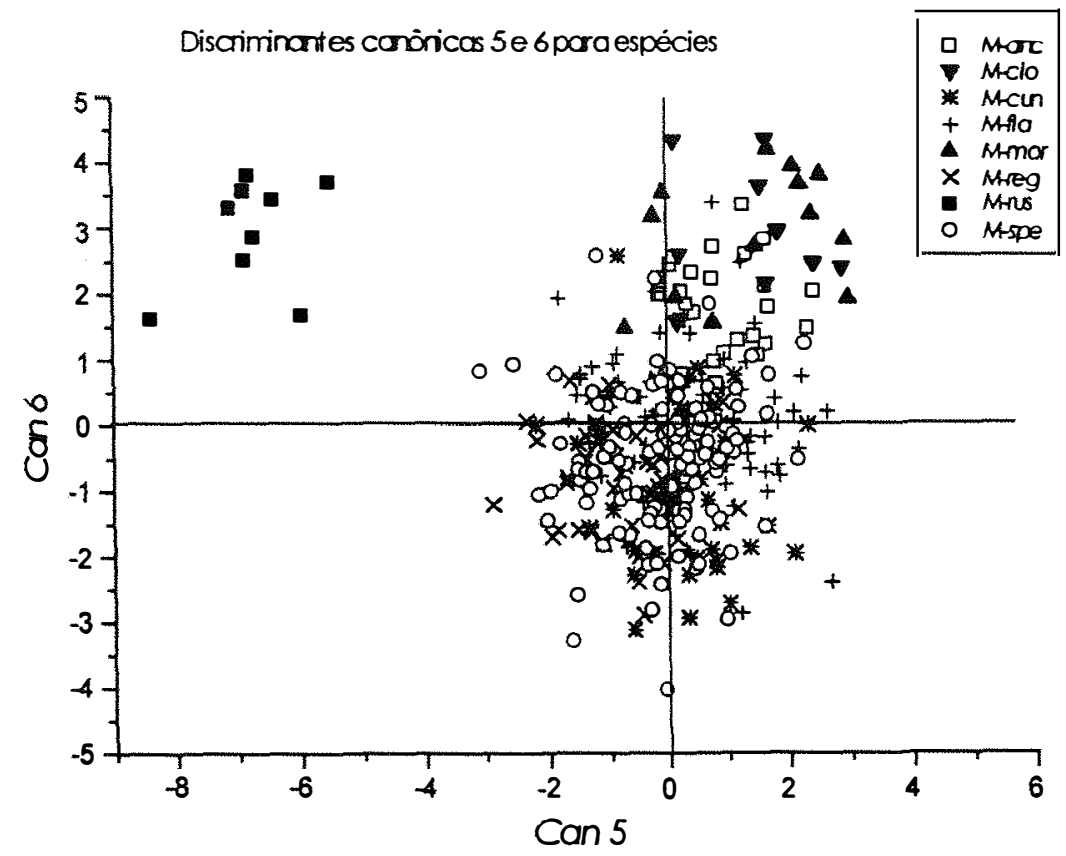

FIGURA 7. Escores provenientes da análise discriminante canônica entre espécies de Miltonia Ldl. (Orchidaceae), considerando Can5 e Can6.

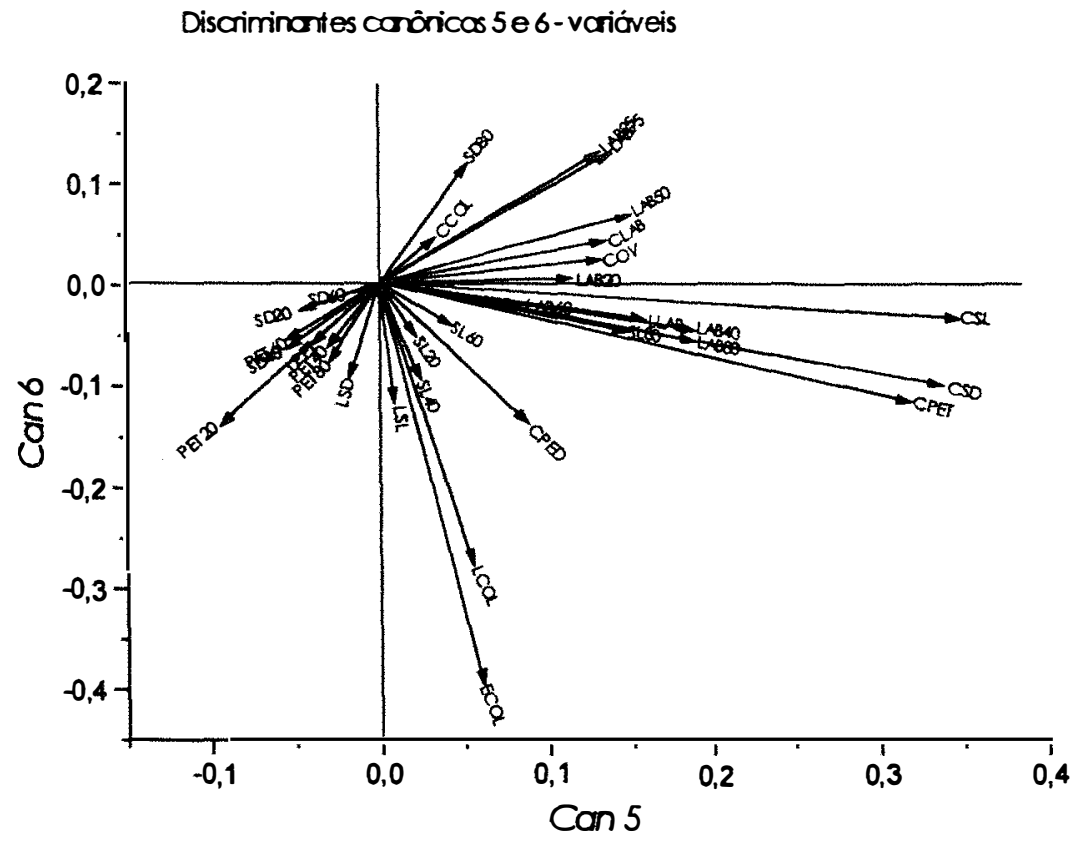

FIGURA 8. Contribuiçāo das variáveis originais para os eixos canônicos 5 e 6 entre espécies de Miltonia Ldl. (Orchidaceae), utilizando coeficientes estandardizados. 


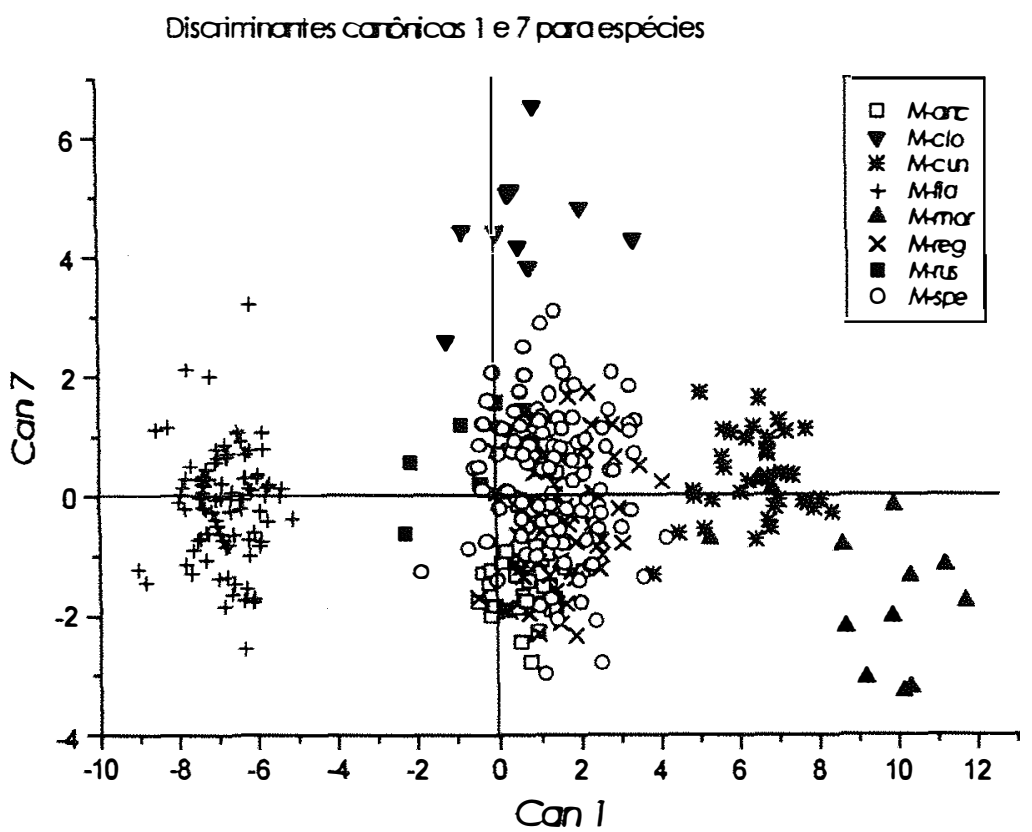

FIGURA 9. Escores provenientes da análise discriminante canônica entre espécies de Miltonia Ldl. (Orchidaceae), considerando Canl e Can7.

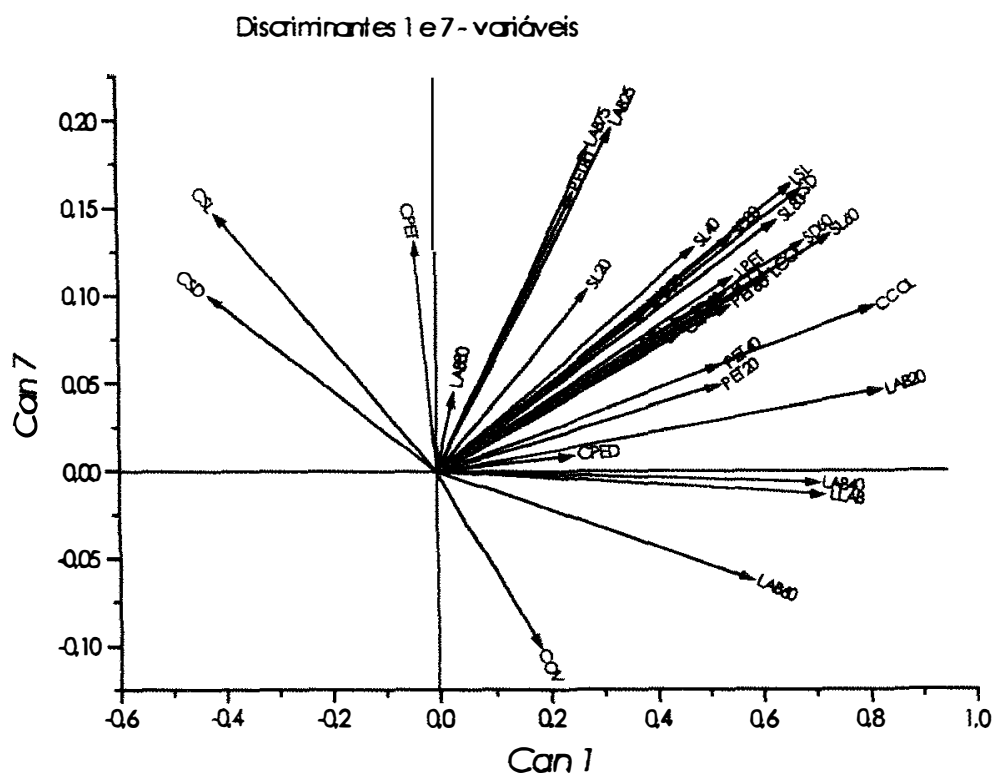

FIGURA 10. Contribuição das variáveis originais para os eixos canônicos 1 e 7 entre espécies de Miltonia Ldl. (Orchidaceae), utilizando coeficientes estandardizados. 


\subsubsection{5.) Análise de agrupamento}

A partir das Distâncias Generalizadas de Mahalanobis interespecífica, obtiveram-se os agrupamento através dos métodos UPGMA e ligação simples.

Utilizando-se do método aglomerativo UPGMA, observa-se que as espécies mais próximas são $M$. clowesii e $M$. regnellii, seguidas de M. anceps e M. spectabilis. Estes resultados são concordantes com Pabst \& Dungs (1977). Estes dois grupos são reunidos e depois associados ao grupo formado por M. flavescens e M. russeliana. Estes resultados são coerentes, pois $M$. flavescens e M. russeliana apresentam formas diferenciadas entre si e em relação às outras. M. cuneata distingue-se principalmente por caracteres relacionados à forma. M. spectabilis var. moreliana é o mais distante taxon em relação aos demais, devido principalmente a caracteres associados ao tamanho. Assim, reafirma-se que este taxon deva ser elevado ao nível de espécie (Figura 11).

Os resultados obtidos pelo método de ligação simples são semelhantes. As espécies mais próximas são $M$. clowesii e $M$. regnellii, associadas ao grupo M. anceps e M. spectabilis. A este grupo inicial são adicionadas em seqüência as espécies $M$. russeliana, $M$. flavescens, $M$. cuneata e M. spectabilis var. moreliana. Novamente, este último taxon mostra-se o mais distante dos demais (Figura 12). 
Fenograma para espécies

UPGMA

Distância de Mahalanobis

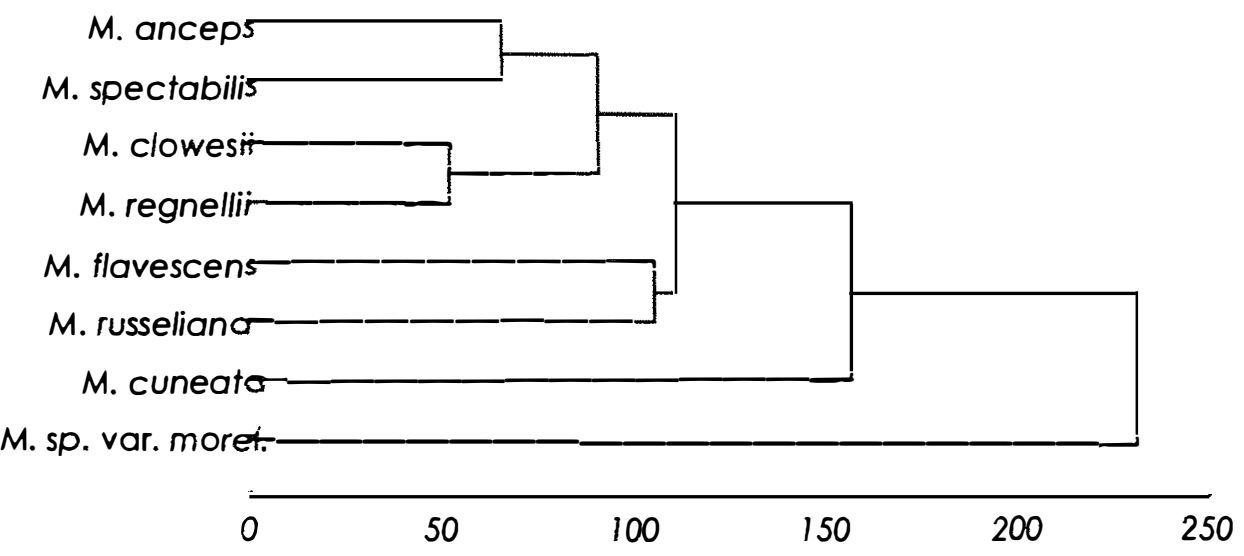

FIGURA 11. Agrupamento, através do método UPGMA, dos oito taxa de Miltonia Ldl. (Orchidaceae) analisados, considerando os 32 caracteres florais avaliados.

Fenograma para espécies

Ligação Simples

Distância de Mahalanobis

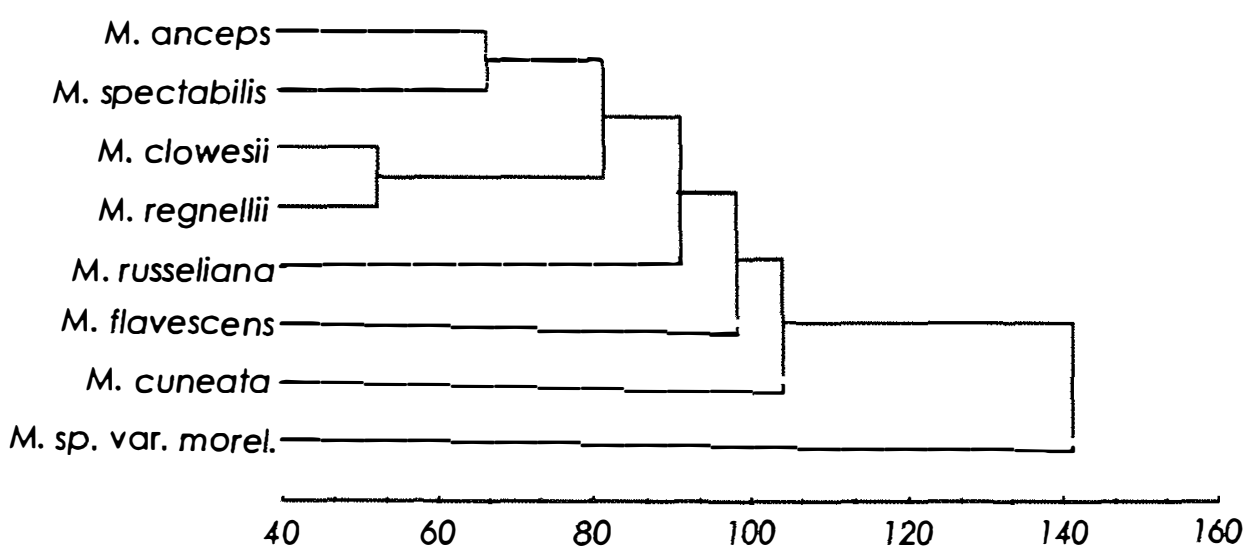

FIGURA 12. Agrupamento, através do método de ligação simples, de oito taxa de Miltonia Ldl. (Orchidaceae) analisados, considerando os 32 caracteres florais avaliados. 


\subsubsection{6.) Análise de época e de intensidade de florescimento}

Observando-se a Figura 13, vemos que as espécies $M$. clowesii e M. regnellii têm pico de florescimento no mesmo período, março. Aqui, novamente estas espécies se parecem, em concordância com Pabst \& Dungs (1977) e os fenogramas representados acima. As espécies $M$. cuneata, $M$. flavescens e $M$. spectabilis têm pico de florescimento em outubro. M. russeliana e M. spectabilis var. moreliana em agosto e, M. anceps em janeiro. Podemos observar que, em alguns casos, embora os picos sejam diferentes, há sobreposição de época de florescimento, não havendo total isolamento reprodutivo temporal, permitindo, portanto, o cruzamento entre alguns destes taxa, se não houver nenhuma outra forma de isolamento reprodutivo presente.

Uma observação importante é que as épocas de florescimento de $M$. spectabilis e de $M$. spectabilis var. moreliana são diferentes. Isto é concordante com os resultados obtidos pelas análises multivariadas e também com os obtidos por Martins (1967).

Diferenças quanto a época de florescimento são importantes pois, podem dificultar ou impedir o fluxo de genes entre taxa, o que contribui ainda mais para a diferenciação entre eles no decorrer do tempo. 
Época e intensidade de florescimento das espécies de Miltonia Ldl. (Orchidaceae).

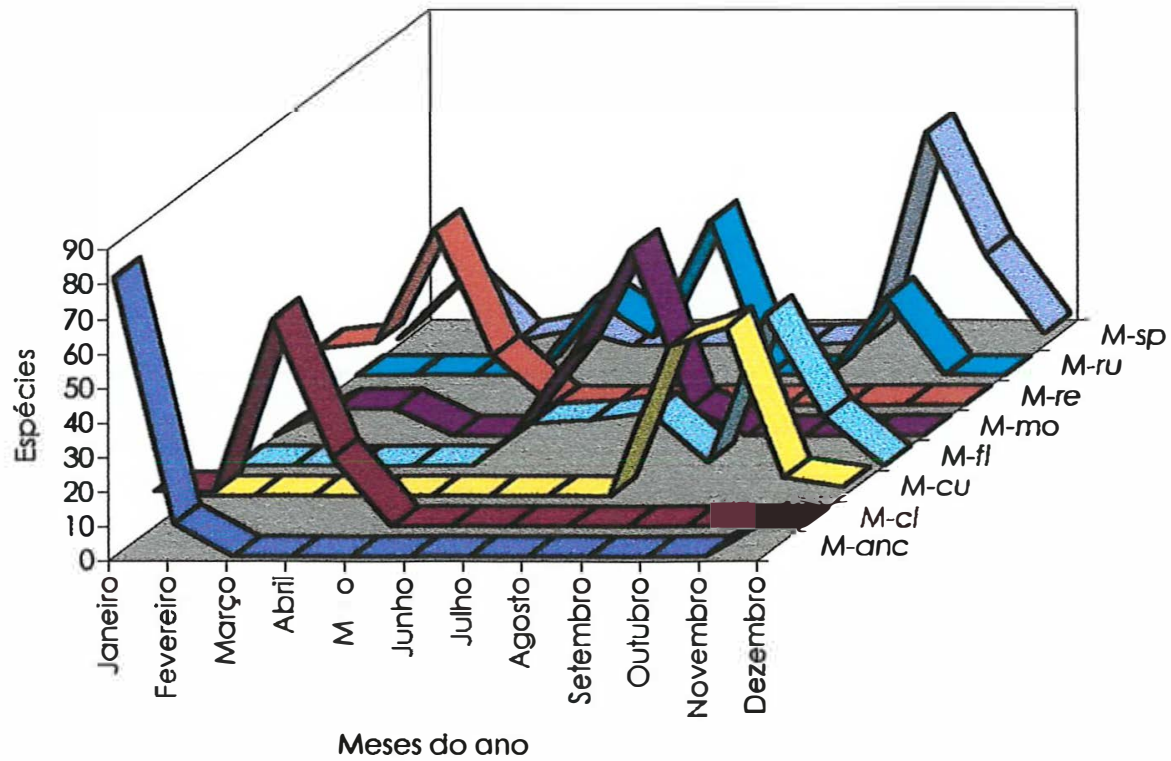

FIGURA 13. Épocas e intensidade (em porcentagem) de florescimento dos taxa avaliados em Miltonia Ldl. (Orchidaceae). $(M-a n c=$ Miltonia anceps; $M-C l=M$. clowesii; $M-C U=M$. cuneata; $M-f l=M$. flavescens; $M-m o=M$. spectabilis var. moreliana; $M$-re $=M$. regnellii; $M$-ru $=M$. russeliana; $M$-sp $=M$. spectabilis. $)$

4.1.2.) Entre Miltonia spectabilis e M. spectabilis var. moreliana

Análises envolvendo somente M. spectabilis e M. spectabilis var. moreliana, visaram estudo mais detalhado entre elas, para verificar se elas constituem apenas variedades de uma espécie ou se elas constituem espécies diferentes. 


\subsubsection{1.) Análise discriminante canônica (CDA)}

Tendo em vista que somente dois grupos taxonômicos estão sendo avaliados, M. spectabilis e M. spectabilis var. moreliana, temos apenas um eixo canônico Can 1, cujo autovalor é 10,43. Como podemos ver na Figura 14, este eixo canônico separa completamente um taxon do outro, o que novamente sugere que eles devem ser classificados como espécies distintas. As principais características que influem nesta separação são as medidas de largura das peças florais, principalmente as relacionadas ao labelo, que são positivamente correlacionadas a este eixo. Largura e espessura de coluna correlacionam-se negativamente com este eixo e também apresentam certa influência na separação destes taxa (Tabela 9).

A distância de Mahalanobis entre estes taxa é 113,31, que é relativamente alto, quando comparado com as distâncias entre os demais taxa (Tabela 7). O teste $F$ indica que esta distância é significativa, com probabilidade de $0,01 \%$ de erro do tipo 1 .

A classificação dos indivíduos em grupos feita pela análise de funções discriminantes foi concordante com a classificação prévia em $100 \%$ dos casos. 


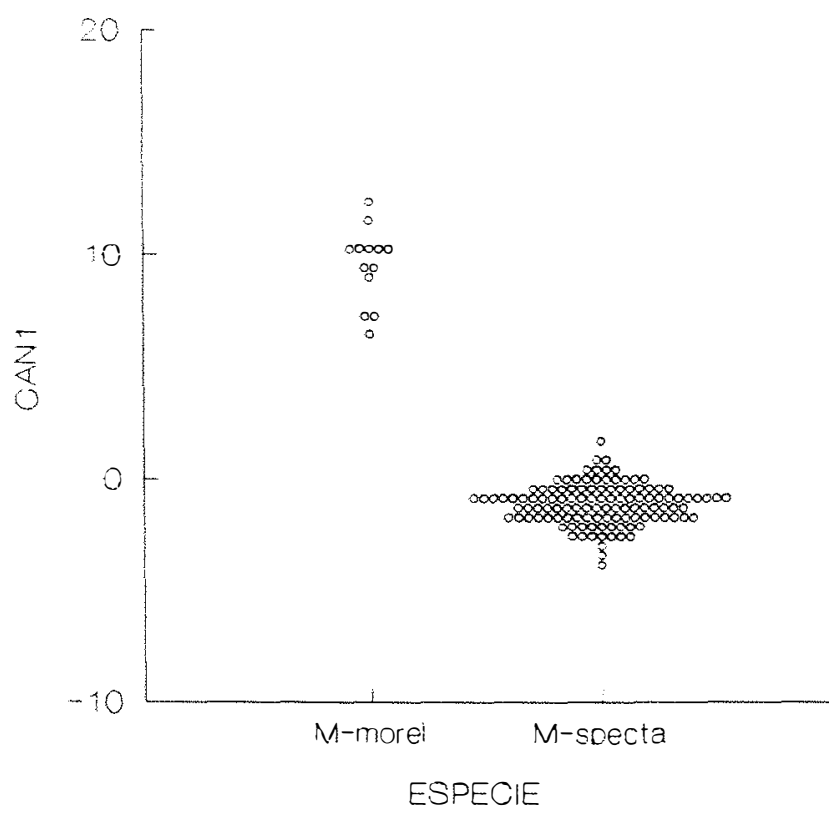

FIGURA 14. Escores provenientes da análise discriminante canônica entre Miltonia spectabilis Ldl. e M. spectabilis var. moreliana Henfrey, considerando Can 1. 
TABELA 9. Coeficientes canônicos totais para Miltonia spectabilis Ldl. e M. spectabilis var. moreliana Henfrey.

\begin{tabular}{lr}
\hline \multicolumn{1}{c}{ Variáveis } & $\begin{array}{r}\text { Coeficientes } \\
\text { canônicos totais }\end{array}$ \\
\hline CSD & 0,2230 \\
LSD & 0,3123 \\
CSL & 0,2782 \\
LSL & 0,4170 \\
CPET & 0,2420 \\
LPET & 0,4873 \\
CPED & 0,1275 \\
CLAB & 0,5416 \\
LLAB & 0,8249 \\
COV & $-0,1136$ \\
CCOL & 0,0220 \\
LCOL & $-0,2919$ \\
ECOL & $-0,3776$ \\
LAB20 & 0,8754 \\
LAB40 & 0,8134 \\
LAB60 & 0,8153 \\
LAB80 & 0,2530 \\
SD20 & $-0,1998$ \\
SD40 & 0,0939 \\
SD60 & 0,5219 \\
SD80 & 0,4695 \\
SL20 & $-0,1519$ \\
SL40 & 0,2396 \\
SL60 & 0,6106 \\
SL80 & 0,4316 \\
PET20 & 0,0630 \\
PET40 & 0,4596 \\
PET60 & 0,5081 \\
PET80 & 0,0829 \\
LAB25 & 0,3607 \\
LAB50 & 0,5193 \\
LAB75 & 0,3306 \\
\hline &
\end{tabular}

4.1.2.2.) Análise da época e de intensidade de florescimento

Observa-se que M. spectabilis e M. spectabilis var. moreliana têm épocas diferentes de florescimento (Figura 15), vindo a confirmar 
que o segundo taxon deva elevado ao nível de espécie, como sugerido por Martins (1967) e Warner (citado por McQueen \& McQueen, 1993).

Época e intensidade de florescimento em Miltonia spectabilis

Ldl. e Miltonia spectabilis var. moreliana Henfrey

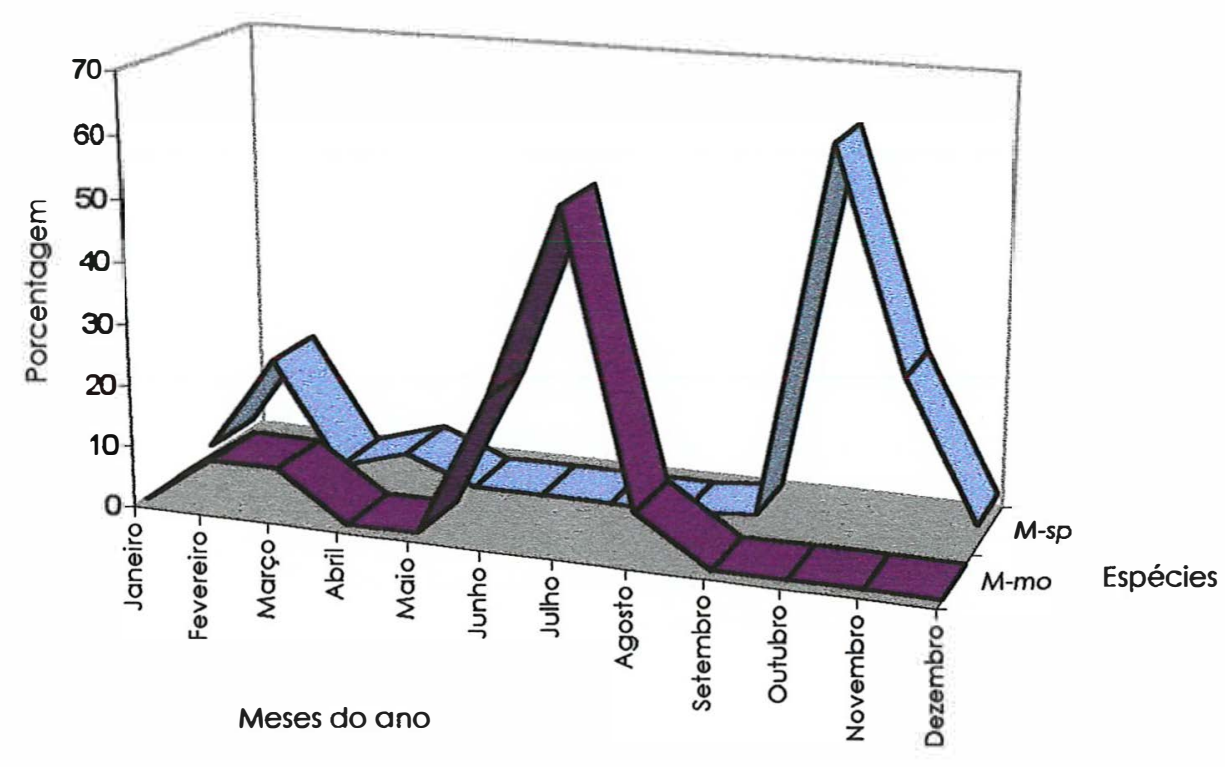

FIGURA 15. Épocas e intensidade (em porcentagem) de florescimento Miltonia spectabilis Ldl. e Miltonia spectabilis var. moreliana Henfrey. (M. mo. $=$ M. spectabilis var. moreliana; $M$. sp. $=$ M. spectabilis.)

É interessante complementar que $M$. spectabilis var. moreliana ocorre no Brasil somente em Canário, no norte do Espírito Santo e em Juçari, no sul da Bahia. Estes locais estão numa mesma região, e portanto, apresentam as mesmas características biogeográficas. Esta região apresenta grande originalidade fitogeográfica, sendo denominada formação florestal perenifólia latifoliada higrófila hileana (Lima, 1966). Além disto, esta região corresponde a um dos refúgios do Pleistoceno. M. spectabilis var. 
moreliana ocorre também no Alto Orinoco, na Amazônia Venezuelana, como relatado por Duntersville (1964).

Por outro lado, M. spectabilis encontra-se no litoral norte de São Paulo até o sul do Espírito Santo (Muqui) e também no estado do Rio de Janeiro. Assim, as áreas de distribuição de $M$. spectabilis e de $M$. spectabilis var. moreliana são disjuntas. Este isolamento geográfico, por dificultar ou impedir o fluxo gênico, contribui ainda mais para a diferenciação entre elas.

\section{2.) Dentro de espécies}

As análises discriminante canônica e de agrupamento dentro de cada espécie visaram avaliar o comportamento das diferentes populações de uma mesma espécie quanto aos padrões de variabilidade. Dados de fenologia e biogeográficos também foram considerados. Vale chamar novamente a atenção para o desbalanceamento no número de indivíduos entre populações de uma mesma espécie e para os problemas decorrentes deste fato. Porém, mais uma vez as análises tiveram caráter exploratório.

\subsection{1.) Dentro de Miltonia flavescens}

\subsubsection{1.) Análise discriminante canônica (CDA)}

Obtiveram-se apenas três variáveis canônicas (Tabela 10), uma vez que somente quatro populações foram consideradas: Paraguai (fl1), Piracicaba - SP (fl2), Petrópolis - RJ (fl3) e Juçari - BA (fl). As demais 
populações não foram incluídas por apresentarem pequeno tamanho amostral.

TABELA 10. Variáveis canônicas entre populaçōes de Miltonia flavescens Ldl., seus autovalores, diferenças entre estes autovalores, proporção da variância total representada por cada variável canônica e proporção cumulativa da variância com o acréscimo de variáveis canônicas.

\begin{tabular}{ccccc}
\hline Var. Canôn. & Autovalor & Diferença & Proporção & Cumulativo \\
\hline Can1 & 7.9425 & 5.5858 & 0.6954 & 0.6954 \\
Can2 & 2.3567 & 1.2342 & 0.2063 & 0.9017 \\
Can3 & 1.1225 & - & 0.0983 & 1.0000 \\
\hline
\end{tabular}

A primeira variável discriminante canônica (Can l) separa as populaçōes em dois grupos, o primeiro localizado à esquerda deste eixo, é representado pela população de Juçari - BA, enquanto que o segundo, à direita deste eixo é formado pelas demais populações (Figura 16). As plantas de Juçari - BA apresentam labelo mais largo e menor espessura de coluna (Figura 17). O segundo eixo canônico (Can2) separa a população de Petrópolis - RJ das demais (Figura 16). Esta apresenta pétalas mais estreitas e largura de coluna maior (Figura 17). Novamente, as populações do Paraguai e de Piracicaba - SP estão juntas, podendo indicar maior semelhança entre elas, o que pode ser observado na matriz de distância entre locais (Tabela 11) e também nos fenogramas (Figuras 20 e 21). O terceiro eixo canônico (Can3) separa a população paraguaia das demais (Figura 18), caracterizada por plantas de labelos mais largos, sépalas laterais e coluna mais estreitas (Figura 19).

A classificação dos indivíduos em grupos feita pela análise de funções discriminante concordou em 100\% com a classificação prévia. 
TABELA 11. Distância generalizada de Mahalanobis entre populações de Miltonia flavescens Ldl. e probabilidades de F.

\begin{tabular}{ccc}
\hline Populações & Distâncias & Probabilidade $\mathrm{F}$ \\
\hline $\mathrm{fll}-\mathrm{fl} 2$ & 17,36515 & 0,2015 \\
$\mathrm{fl1}-\mathrm{fl} 3$ & 34,93638 & 0,0191 \\
$\mathrm{fll}-\mathrm{fl} 4$ & 37,61371 & 0,0003 \\
$\mathrm{fl} 2-\mathrm{fl} 3$ & 28,42712 & 0,0022 \\
$\mathrm{fl} 2-\mathrm{fl} 4$ & 35,46789 & $<0,0001$ \\
$\mathrm{fl} 3-\mathrm{fl} 4$ & 42,84452 & $<0,0001$ \\
\hline
\end{tabular}




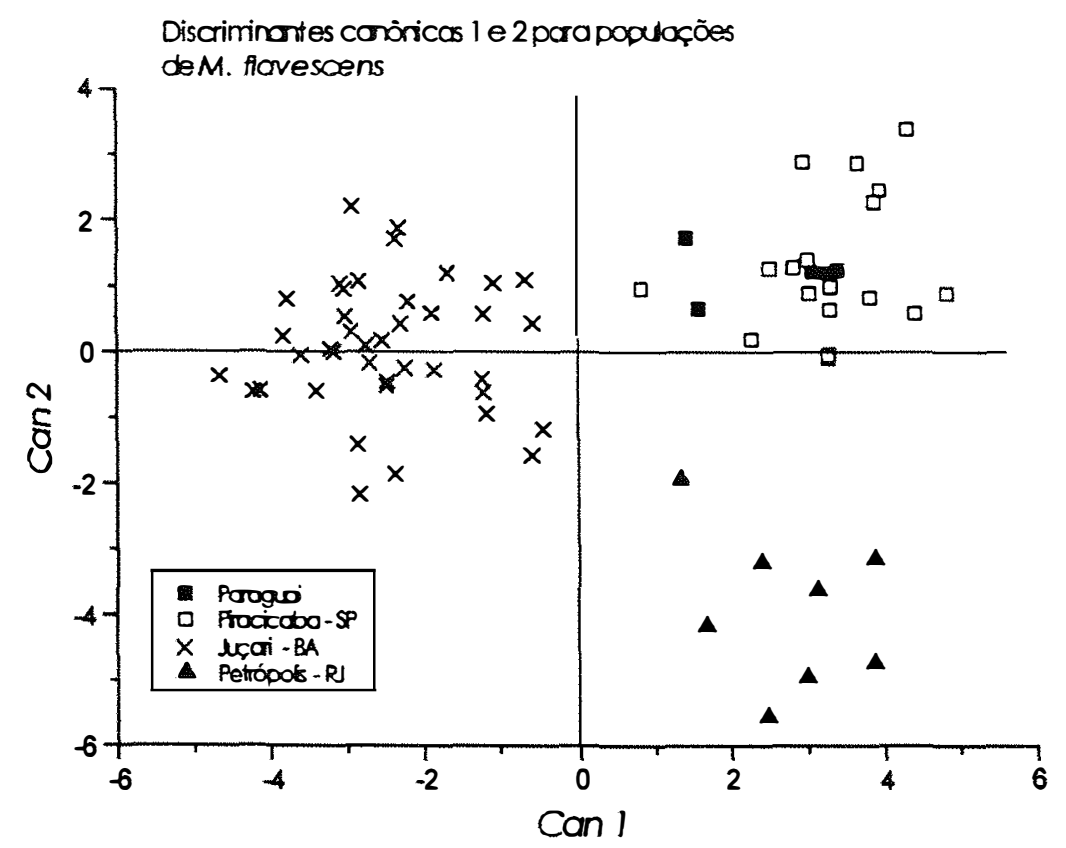

FIGURA 16. Escores provenientes da análise discriminante canônica entre populações de Miltonia flavescens Ldl., considerando Can1 e Can2.

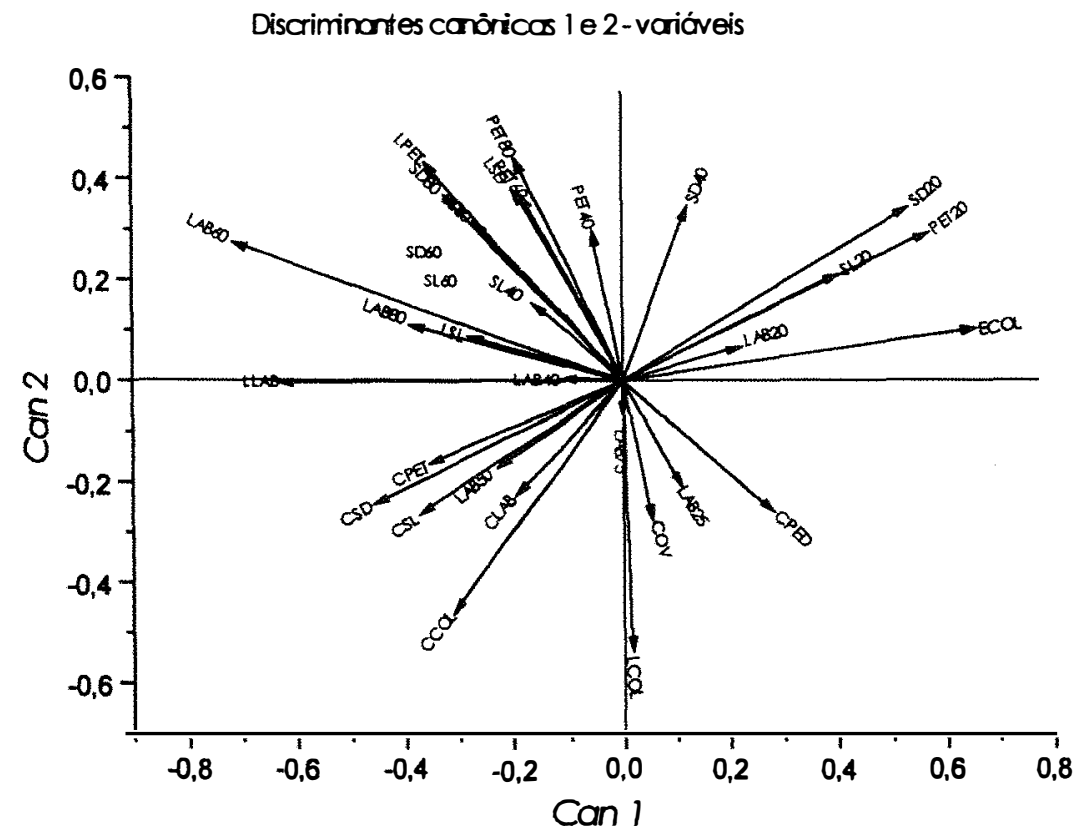

FIGURA 17. Contribuição das variáveis originais para os eixos canônicos 1 e 2 entre as populações de Miltonia flavescens Ldl., utilizando coeficientes estandardizados. 


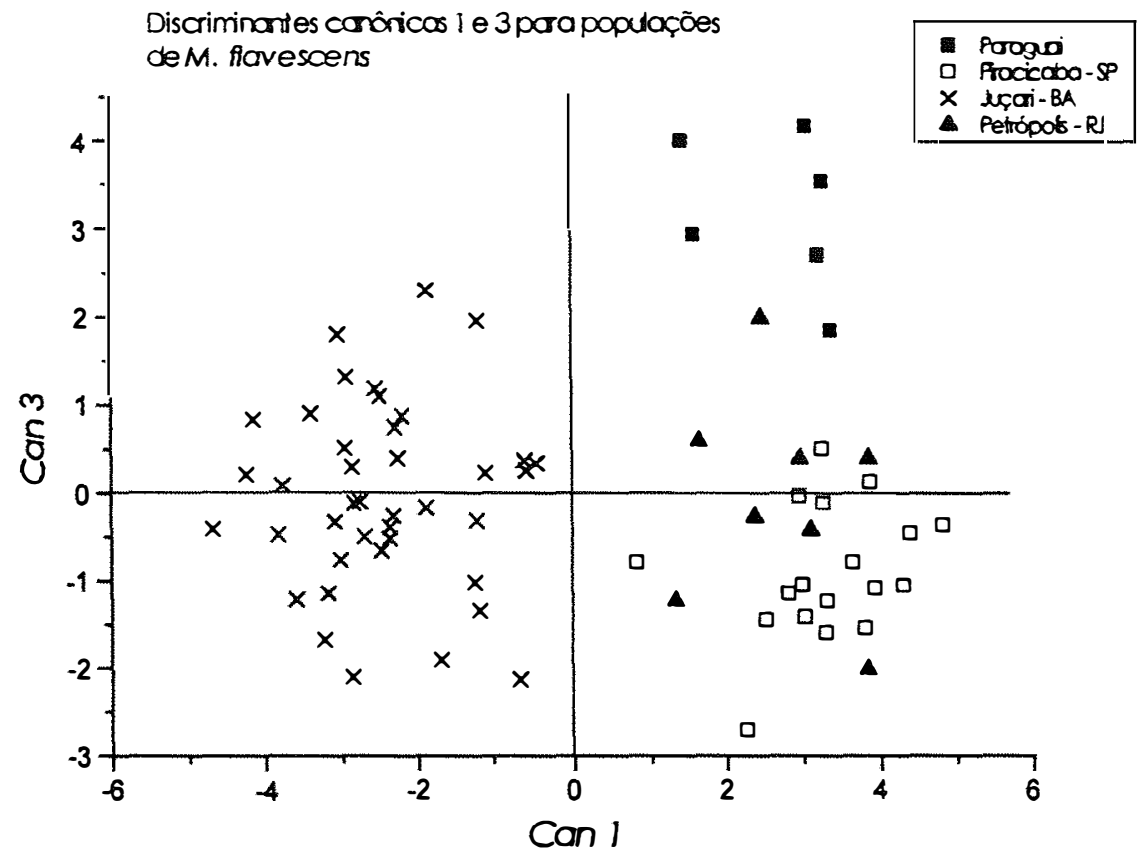

FIGURA 18. Escores provenientes da análise discriminante canônica entre populações de Miltonia flavescens Ldl., considerando Can 1 e Can3.

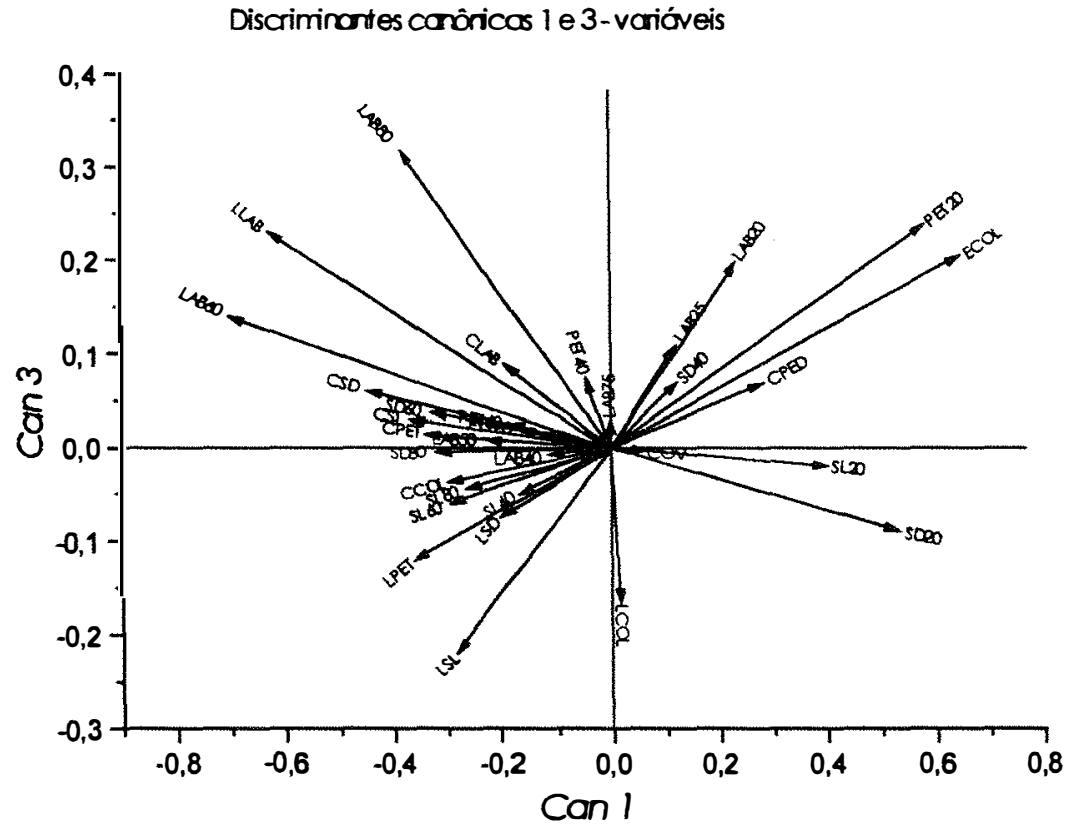

FIGURA 19. Contribuição das variáveis originais para os eixos canônicos 1 e 3 entre as populações de Miltonia flavescens Ldl., utilizando coeficientes estandardizados. 


\subsubsection{2.) Análise de agrupamento}

De acordo com os fenogramas obtidos pelos métodos UPGMA e ligação simples, as populações do Paraguai e de Piracicaba SP, apesar da distância espacial, são mais semelhantes morfologicamente entre si quanto aos caracteres florais (Figuras 20 e 21). Isto se deve, possivelmente, às semelhanças fitogeográfica e ecológica, que vão de São Paulo até o Paraguai. É interessante notar que nenhuma delas localiza-se nos refúgios do Pleistoceno. Em ambos os fenogramas a população de Juçari - BA é a mais distante. Isto era esperado porque ela se localiza no extremo norte da distribuição geográfica aqui considerada para esta espécie. Além disto, esta região, conhecida por hilea bahiana, apresenta grande originalidade fitogeográfica e coincide com um dos refúgios do Pleistoceno, o que justifica a sua maior diferenciação em relação às demais.

Portanto, de acordo com CDA e análise agrupamento, a população de Juçari - BA se distingue das demais. Isto possivelmente indica que ela seja, de acordo com a classificação de Grant (1963), uma raça da espécie. Este mesmo resultado foi observado por Martins (1970) para esta população, a qual ele classificou como subespécie. Observa-se também que há um gradiente no sentido norte - sul, quando se consideram as demais populações de M. flavescens (Figuras 20 e 21). 
Fenograma para populações de M. flavescens

UPGMA

Distância de Mahalanobis

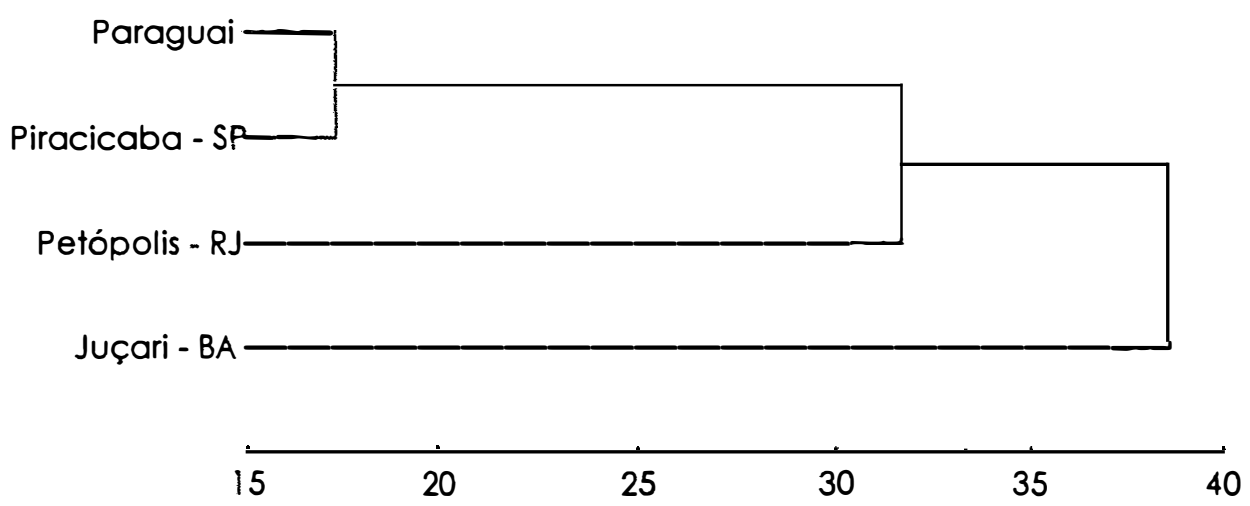

FIGURA 20. Agrupamento, através do método UPGMA, das populaçōes de Miltonia flavescens Ldl. analisadas, considerando os 32 caracteres florais avaliados.
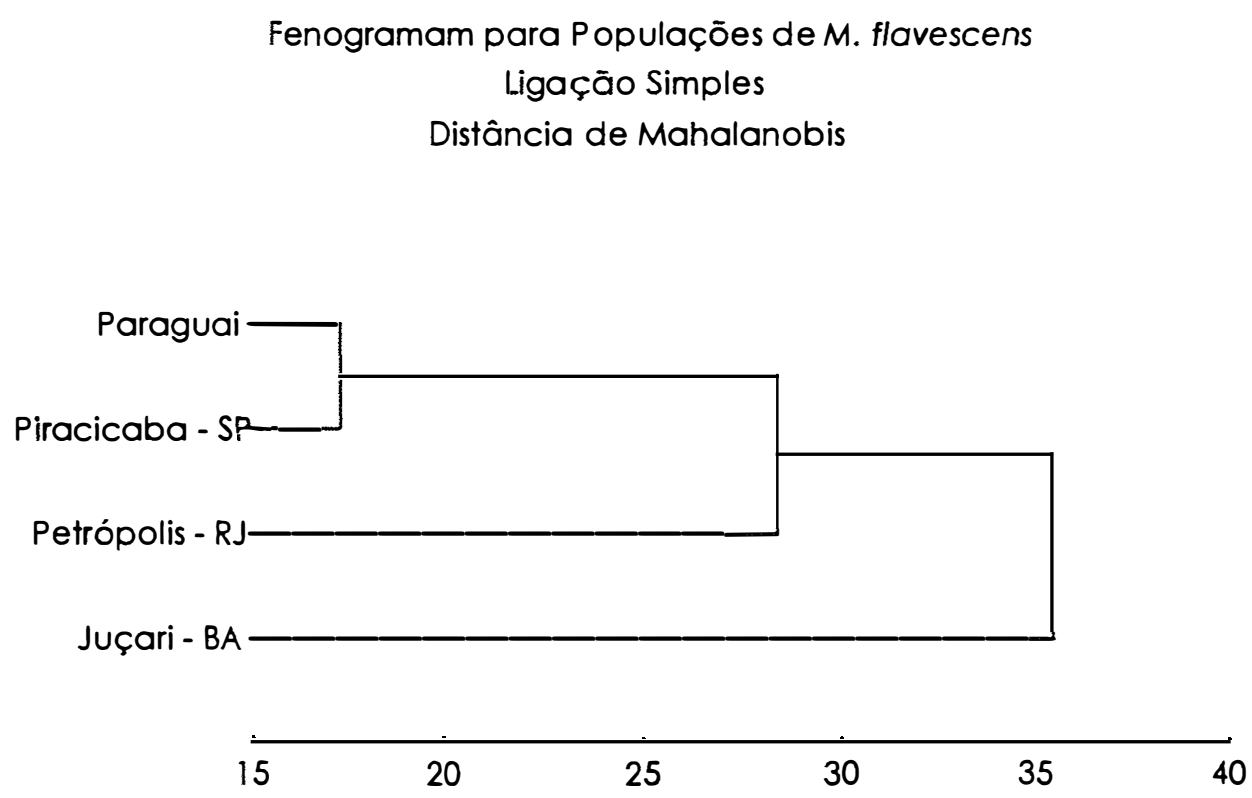

FIGURA 21. Agrupamento, através do método de ligação simples, das populaçōes de Miltonia flavescens Ldl. analisadas, considerando os 32 caracteres florais avaliados. 


\subsubsection{3.) Análise de época e de intensidade de florescimento}

Pelo que se observa na Figura 22, a população de Juçari $\mathrm{BA}(\mathrm{fl}$ ) difere das outras à época e à intensidade de florescimento. As populações do Paraguai (fl]) e de Piracicaba - SP (fl2) são novamente as mais parecidas. A população de Petrópolis - RJ (fl3) é mais parecida com estas duas últimas. Estes resultados confirmam aqueles obtidos pelas análises multivariadas. Mais uma vez, sugere-se que há variação clinal no sentido norte - sul dentro de $M$. flavescens e que a população de Juçari - BA, seja uma raça.

Observam-se também diferenças quanto a época de florescimento desta população em relação às demais. Isto contribui para a diferenciação da mesma, pois resulta em redução ou mesmo eliminação do fluxo gênico entre esta população e as outras, podendo levar ao isolamento reprodutivo. 
Épocas e intensidade (em porcentagem) de florescimento das populações de M. flavescens Ldl.

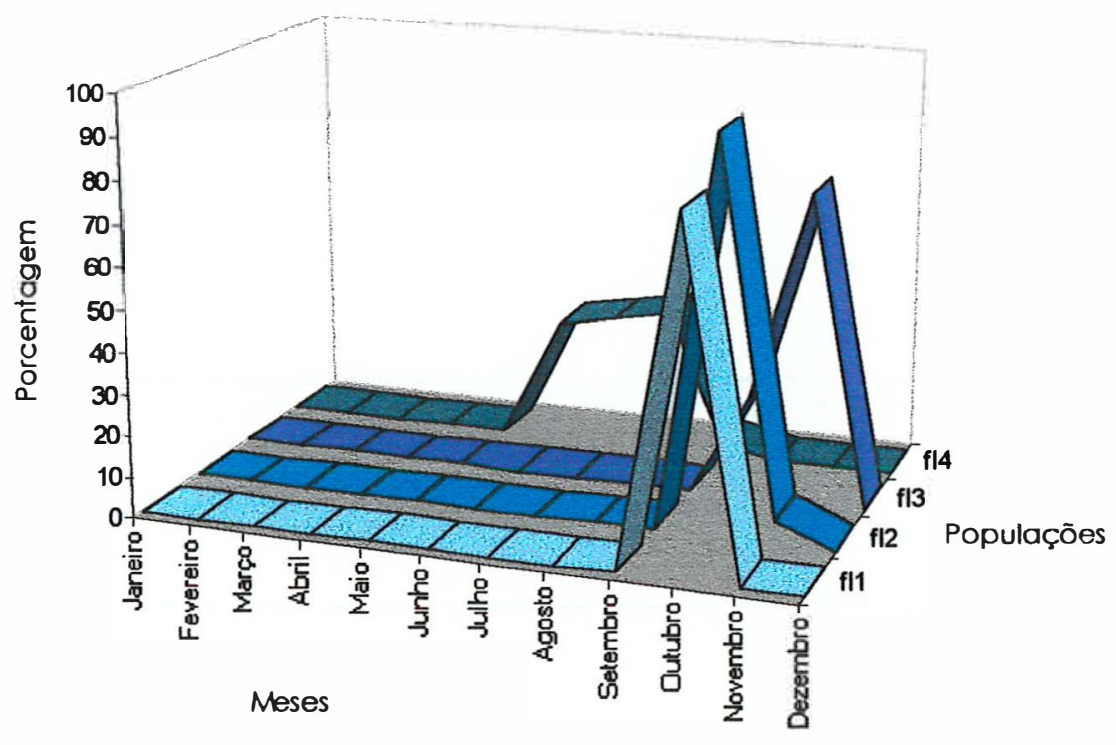

FIGURA 22. Épocas e intensidade (em porcentagem) de florescimento das populações de Miltonia flavescens. Ldl. (fll - Paraguai, fl2 - Piracicaba - SP, fl3 Petrópolis - RJ, fl4 - Juçari - BA).

4.2.2.) Dentro de Miltonia regnellii.

4.2.2.1.) Análise discriminante canônica (CDA)

Em função do tamanho amostral, somente duas populações de $M$. regnellii puderam ser consideradas: a população da região entre São Paulo e norte do Paraná (rel) e a população de Angra dos Reis - RJ (re2). Como somente dois grupos foram considerados apenas um eixo canônico foi produzido, cujo autovalor é 26,24. De acordo com este eixo (Canl) (Figura 23), observa-se que as duas populações separam-se completamente, sendo que as variáveis que mais contribuíram para isto foram $\mathrm{CCOL}$ e LCOL, positivamente 
correlacionadas a este eixo e larguras de peças florais, principalmente PET20, PET40, SL20, LPET, SD20 e CPET, todas negativamente correlacionadas a Canl (Tabela 12). Esta separação completa pode ser indicativo de que as populações sejam, de acordo com Grant (1963), raças diferentes, o que vem a ser confirmado pelo fato de que a Distância de Mahalanobis entre estas duas populações é 113,94, que é um valor relativamente alto, quando comparado às distâncias entre espécies (Tabela 7). O teste $F$ mostrou que esta distância é significativa a $0,07 \%$ de probabilidade de erro tipo I.

A classificação dos indivíduos em grupos obtida pela análise de funções discriminante concordou em 100\% com a classificação prévia.

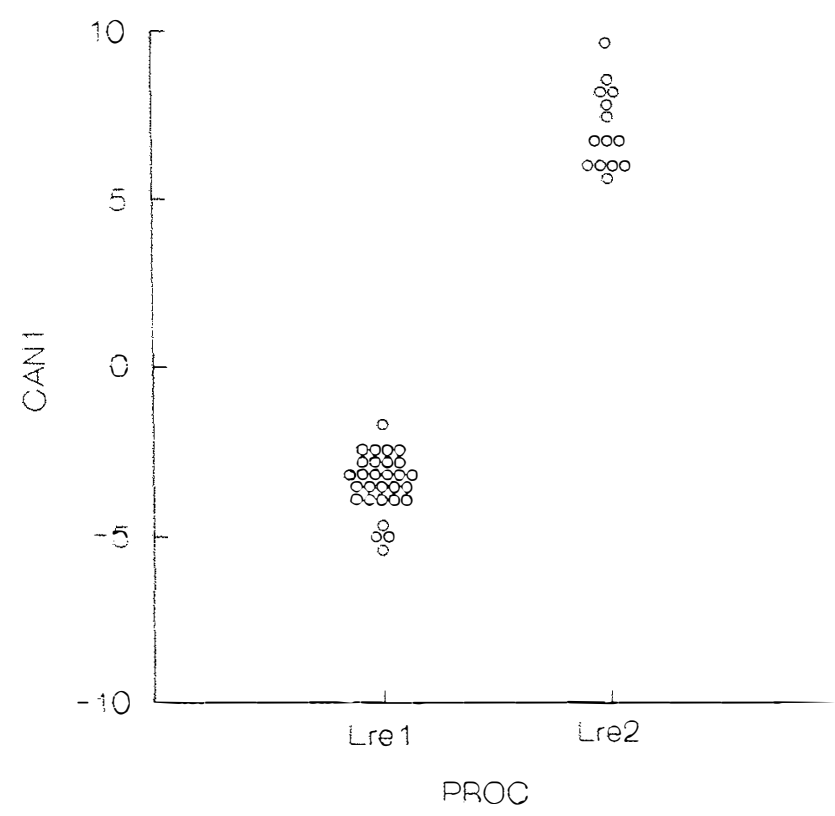

FIGURA 23. Escores provenientes da Análise Discriminante Canônica entre as populações de Miltonia regnellii Reichenbach (f.), considerando Can l. 
TABELA 12. Coeficientes canônicos totais para populaçōes de Miltonia regnellii Reichenbach (f.).

\begin{tabular}{lr}
\hline \multicolumn{1}{c}{ Variáveis } & $\begin{array}{c}\text { Coeficientes } \\
\text { canônicos totais }\end{array}$ \\
\hline CSD & -0.1010 \\
LSD & 0.0507 \\
CSL & -0.0821 \\
LSL & 0.0548 \\
CPET & -0.3202 \\
LPET & -0.3728 \\
CPED & -0.1137 \\
CLAB & -0.2442 \\
LLAB & -0.2425 \\
COV & -0.2990 \\
CCOL & 0.7905 \\
LCOL & 0.6686 \\
ECOL & 0.2538 \\
LAB20 & -0.1581 \\
LAB40 & -0.2658 \\
LAB60 & -0.2722 \\
LAB80 & -0.2972 \\
SD20 & -0.3302 \\
SD40 & -0.1643 \\
SD60 & 0.0150 \\
SD80 & 0.0011 \\
SL20 & -0.4395 \\
SL40 & -0.2682 \\
SL60 & 0.0686 \\
SL80 & 0.1247 \\
PET20 & -0.4677 \\
PET40 & -0.5132 \\
PET60 & -0.2222 \\
PET80 & -0.0398 \\
LAB25 & -0.1217 \\
LAB50 & 0.0937 \\
LAB75 & -0.2092 \\
\hline &
\end{tabular}


4.2.2.2.) Análise de época e de intensidade de florescimento

Como pode ser observado na Figura 24, as populações de M. regnellii apresentam a mesma época de florescimento. Este fato não é discordante da análise discriminante canônica, pois raças diferentes podem florescer na mesma época. Isto indica, que apesar das populações serem diferentes, elas não apresentam isolamento reprodutivo temporal.

Épocas e de florescimento (em porcentagem) das populações de Miltonia regnellii Reichenbach (f.).

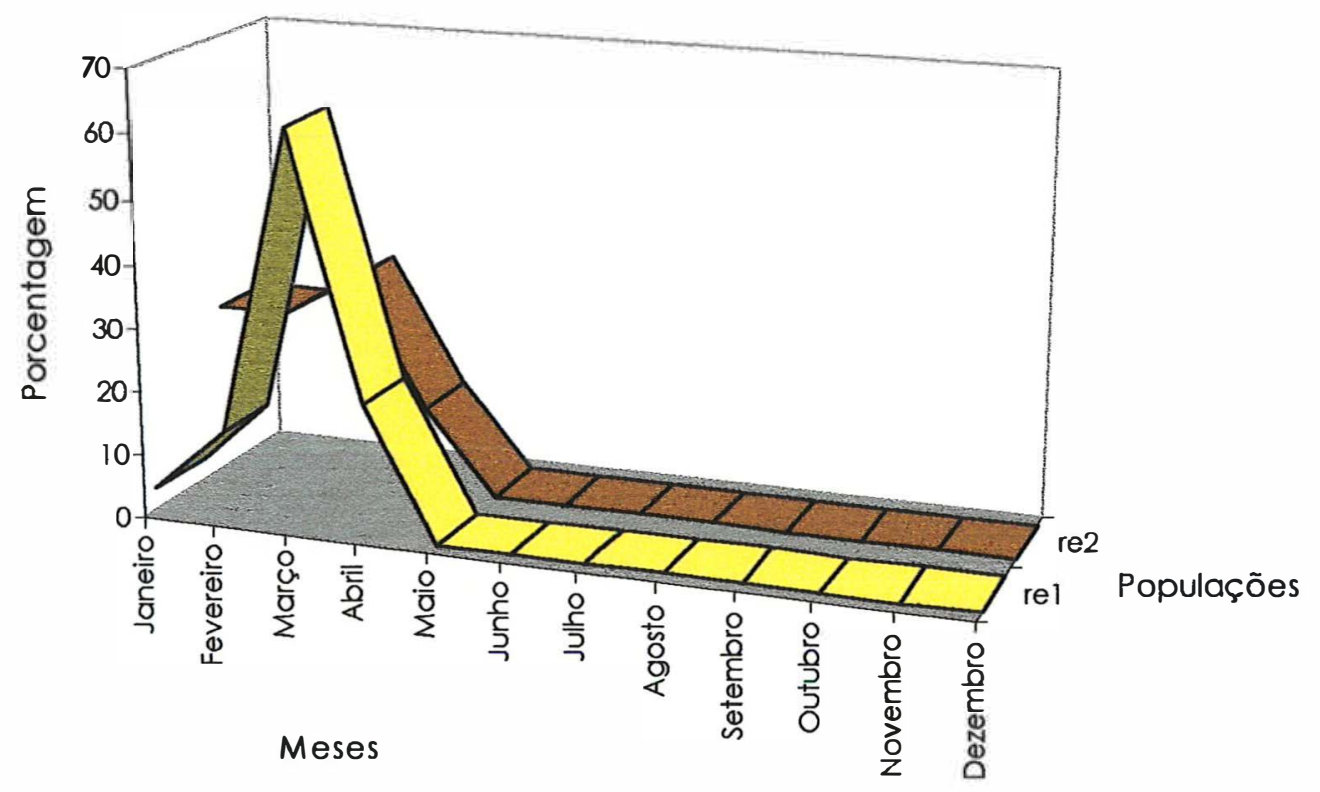

FIGURA 24. Épocas e intensidade (em porcentagem) de florescimento das populações de Miltonia regnellii. Reichenbach (f.). (rel - SP - norte do Paraná, re2 Angra dos Reis - RJ). 


\subsection{3.) Dentro de Miltonia spectabilis.}

\subsubsection{1.) Análise discriminante canônica (CDA)}

Obtiveram-se apenas duas variáveis canônicas (Tabela 13), uma vez que somente três populações foram consideradas: ToqueToque Pequeno - SP (sp1), Petrópolis - RJ (sp2) e Cascata - RJ (sp3). As demais populações não foram incluídas por apresentarem pequeno tamanho amostral.

TABELA 13. Variáveis canônicas entre populaçōes de Miltonia spectabilis Ldl., seus autovalores, diferenças entre estes autovalores, proporção da variância total representada por cada variável canônica e proporção cumulativa da variância com o acréscimo de variáveis canônicas.

\begin{tabular}{ccccc}
\hline Var. Conôn. & Autovalor & Diferença & Proporção & Cumulativo \\
\hline Can1 & 4,0494 & 1,8483 & 0,6478 & 0,6478 \\
Can2 & 2,2011 & - & 0,3522 & 1.0000 \\
\hline
\end{tabular}

O primeiro eixo canônico (Can l) separa as três populações. À esquerda, localiza-se a população de Toque - Toque Pequeno -SP e à direita a de Cascata - RJ. A população de Petrópolis -RJ ocupa posição intermediária, havendo sobreposição entre ela e a população de Cascata - RJ. Esta sobreposição pode indicar variação clinal entre estas populações. Pode-se também observar que dois indivíduos da população de Petrópolis - RJ localizam-se entre os indivíduos da população de Toque - Toque Pequeno - SP (Figura 25). As plantas da população de Toque - Toque Pequeno - SP apresentam labelo mais estreito e maior comprimento de coluna, ao contrário das plantas de Cascata - RJ (Figuras 25 e 26). 
O segundo eixo canônico (Can2) isola a população de Cascata - RJ das demais (Figura 25), principalmente devido ao comprimento do ovário e a caracteres relacionados à coluna (Figura 26). Isto indica que as outras duas populações são mais semelhantes morfologicamente entre si, o que pode ser visto na Tabela 14, que mostra as distâncias de Mahalanobis entre as populações em questão. Possivelmente, há um gradiente de variabilidade no sentido sul - norte, sendo que a população de Cascata pode ser considerada uma raça, segundo a classificação de Grant (1963).

TABELA 14. Distâncias generalizadas de Mahalanobis entre populaçōes de Miltonia spectabilis Ldl. e probabilidades de $\mathrm{F}$.

\begin{tabular}{ccc}
\hline Populaçōes & Distâncias & Probabilidade F \\
\hline sp1 - sp2 & 21.50784 & $<0.0001$ \\
sp1 - sp3 & 70.77965 & $<0.0001$ \\
sp2 - sp3 & 45.54926 & $<0.0001$ \\
\hline
\end{tabular}

A classificação obtida pela análise de funções discriminantes diferiu da classificação prévia. Contudo, houve concordância de $99.11 \%$ entre as duas classificaçōes. 


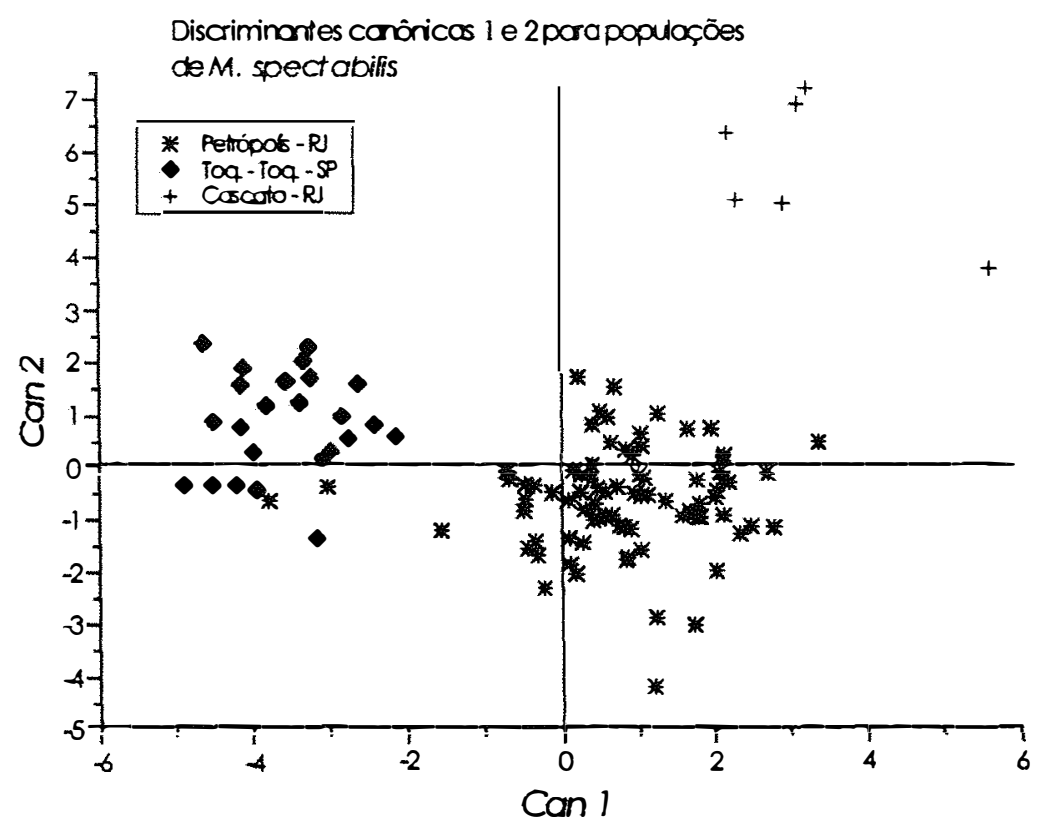

FIGURA 25. Escores provenientes da análise discriminante canônica entre populações de Miltonia spectabilis Ldl., considerando Can 1 e Can2.

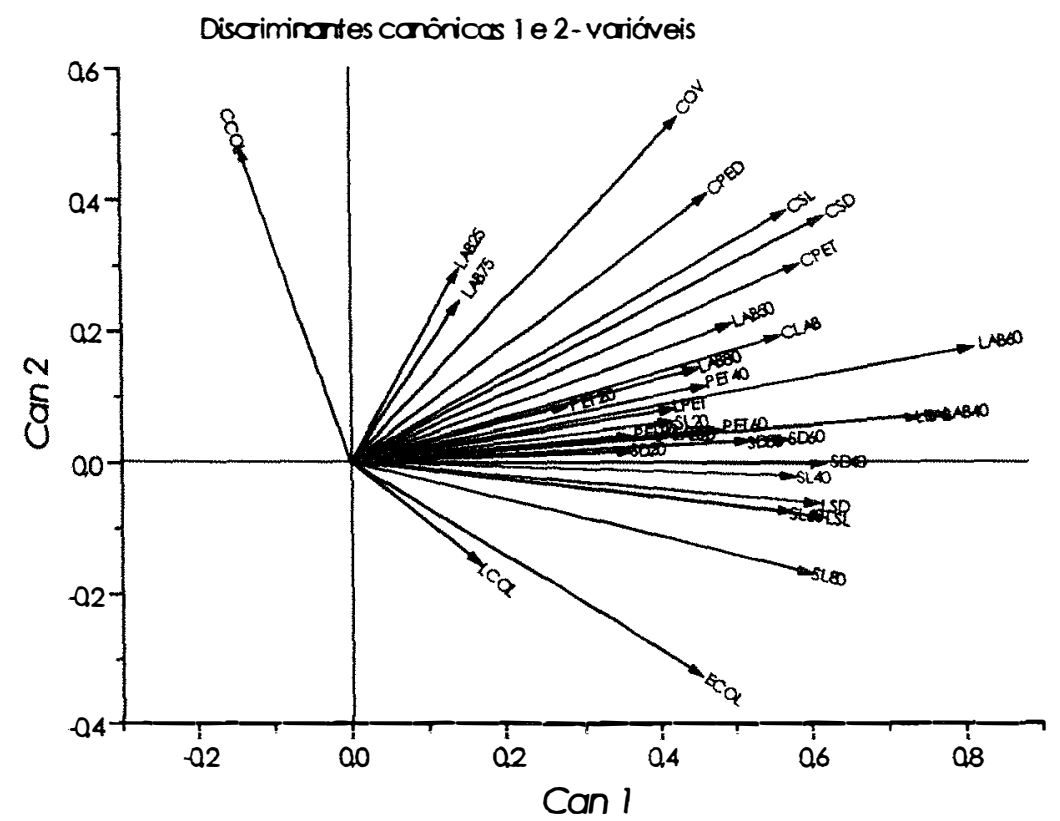

FIGURA 26. Contribuiçāo das variáveis originais para os eixos canônicos 1 e 2 entre as populações de Miltonia spectabilis Ldl., utilizando coeficientes estandardizados. 


\subsubsection{2.) Análise de agrupamento}

Os dois fenogramas obtidos para as populações de $M$. spectabilis (UPGMA e ligação simples) são semelhantes (Figuras 27 e 28). A população de Cascata - RJ é a que mais se distancia das demais. Isto vem a confirmar que esta população constitui uma raça.
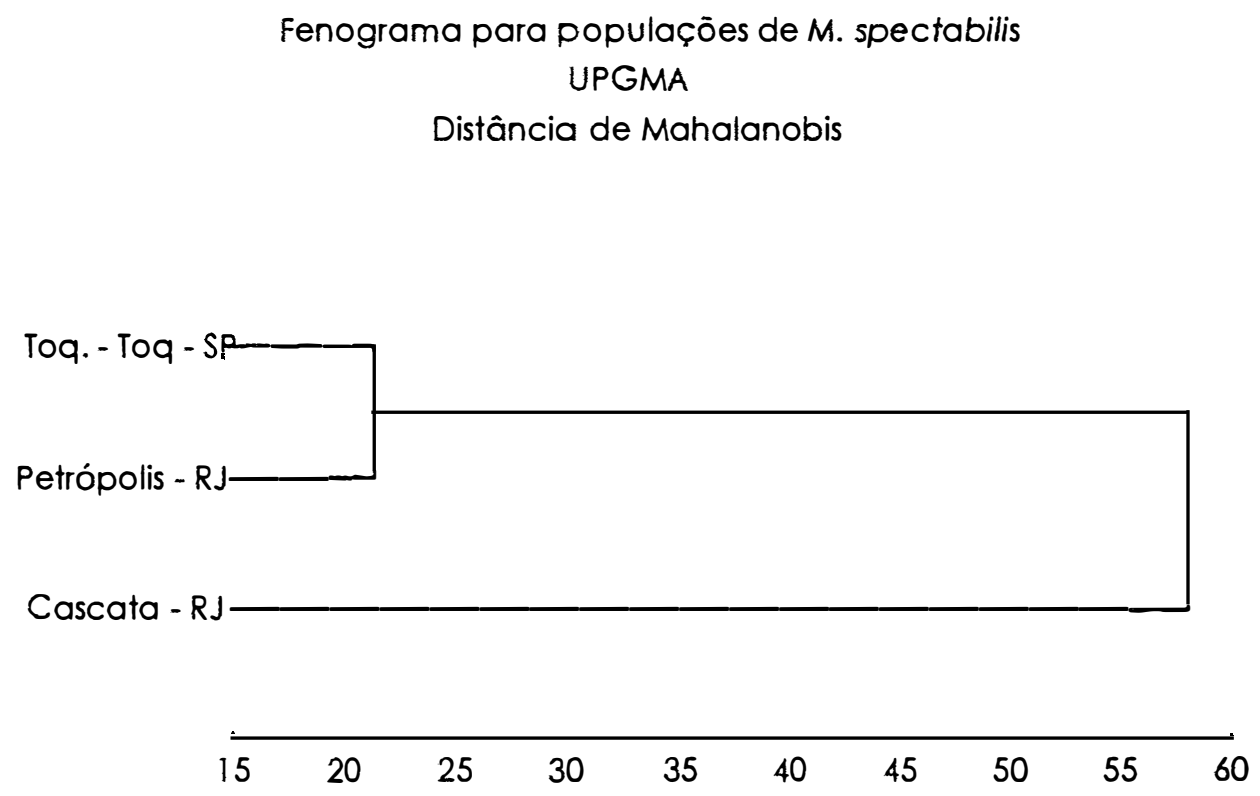

FIGURA 27. Agrupamento, através do método UPGMA, das populaçōes de Miltonia spectabilis Ldl. analisadas, considerando os 32 caracteres florais avaliados. 
Fenograma para populaçōes de M. spectabilis

Ligação simples

Distância de Mahalanobis

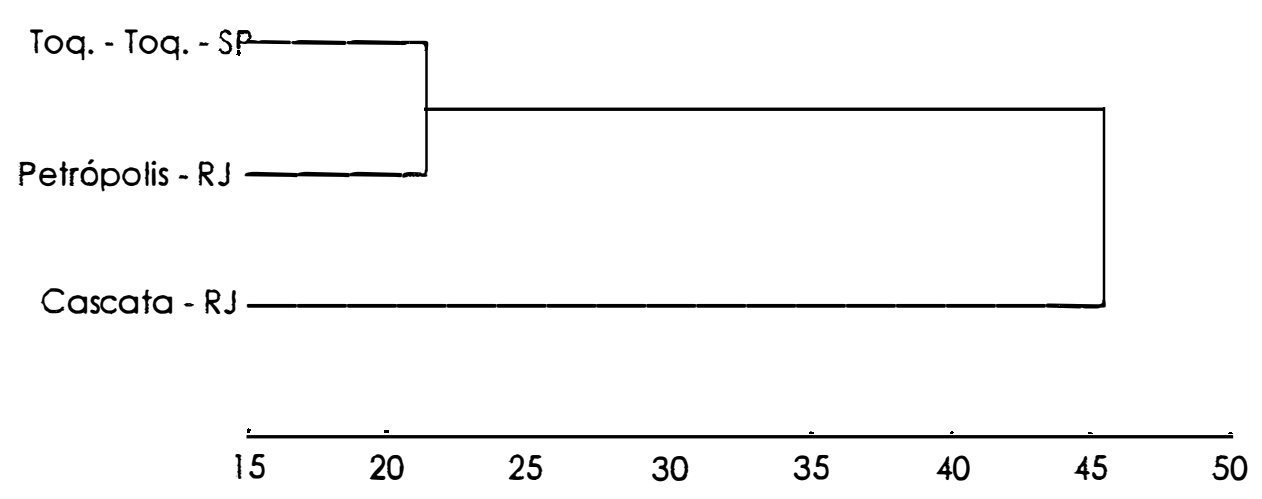

FIGURA 28. Agrupamento, através do método de ligaçōes simples, das populaçōes de Miltonia spectabilis Ldl. analisadas, considerando os 32 caracteres florais avaliados.

4.2.3.3. Análise de época e de intensidade de florescimento

Pelo que pode ser observado na Figura 29 , as populações de Petrópolis - RJ e Toque - Toque Pequeno - SP são mais parecidas entre si. A população de Cascata - RJ (sp3) tem seu pico de florescimento mais distanciado das demais populações. Estes resultados são concordantes com as análise multivariadas realizadas, sendo que, há variação clinal no sentido sul - norte e que a população de Cascata - RJ é uma raça. 
Época e intensidade (em porcentagem) de florescimento das populações de Miltonia spectabilis Ldl.

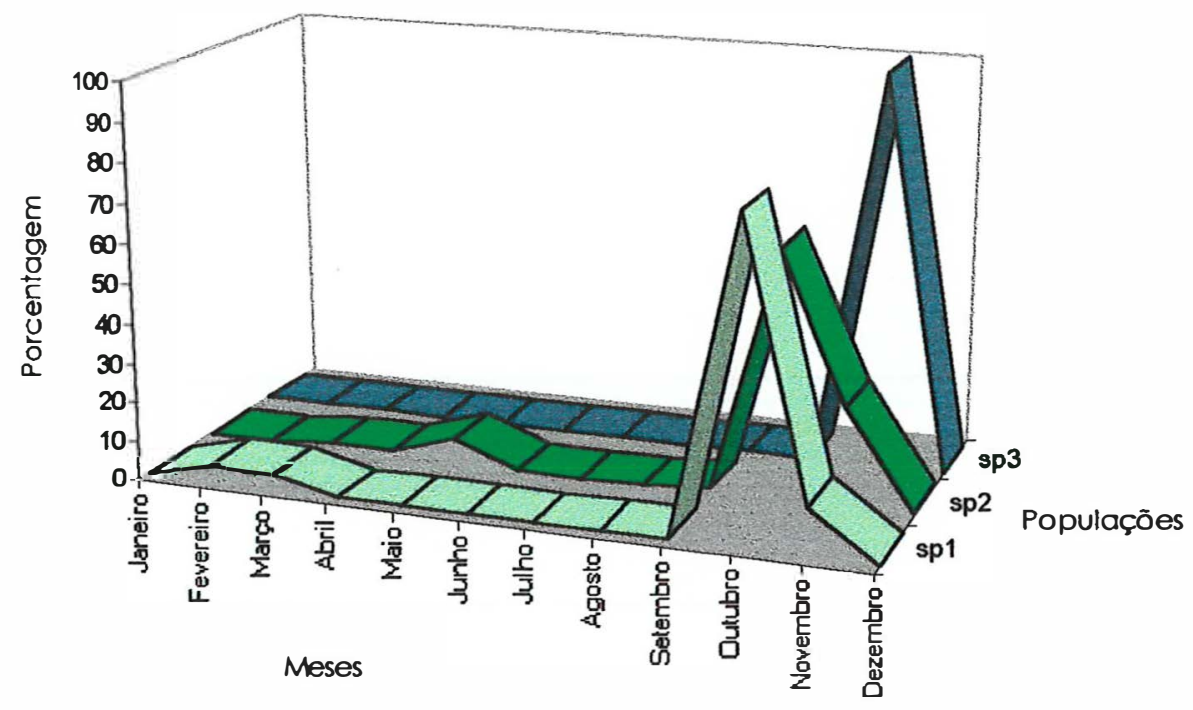

FIGURA 29. Épocas e intensidade (em porcentagem) de florescimento das populações de Miltonia spectabilis Ldl.. (spl - Toque - Toque Pequeno - SP, sp2 Petrópolis - RJ, sp3 - Cascata - RJ). 


\section{5.) CONCLUSÕES}

a) Há variação clinal no sentido norte-sul dentro da espécie Miltonia flavescens Ldl., sendo que a população de Juçari - BA, deve ser considerada uma raça.

b) As populações de M. regnellii Reichenbach (f.) são raças diferentes, por apresentarem descontinuidade nas características morfológicas.

c) Há variação clinal entre as populações da espécie Miltonia spectabilis, sendo que a população de Cascata - RJ deve ser considerada uma raça.

d) Confirmou-se que Miltonia spectabilis var. moreliana deva ser elevada ao nível de espécie.

e) Diferenças de época de florescimento entre e dentro das espécies de Miltonia reduzem ou impedem o fluxo gênico entre populações de uma mesma espécie ou entre espécies diferentes, podendo levar ao isolamento reprodutivo e conduzir a maior diferenciação entre os taxa. 
f) Populações ou espécies localizadas em áreas de refúgio do Pleistoceno tendem a se diferenciar das demais, sendo que as espécies endêmicas localizam-se nesta área. 


\section{6.) REFERÊNCIAS BIBLIOGRÁFICAS}

ASTHOLM, F.; NYMAN, Y. Morphometric variation in Alonsoa meridionalis complex (Scrophulariaceae). Plant Systematics and Evolution, v.193, p. 53-68, 1994.

BAKER, C.; BAKER R. M. Those other miltonias. American Orchid Society Bulletln, v.64, n.9, p. 976-985, 1995.

BAKER, G. Brazilian miltonias: an appretiation and their culture. American Orchid Society B ulletin, v.59, n.2, p. 149-152, 1990.

BAUM, B. R.; BAILEY, G. A numerical taxonomic investigation of the Hordeum brevisubulatum aggregate. Canadian Journal of Botany, v.69, p. 2011-2009, 1991.

BAUM, B. R.; YANG, J. L.; YEN, C. Taxonomic separation of Kengyilia (Poaceae: Triticaceae) in relation to nearest related Roegneria, Elymus, and Agropyron, based on some morphological characters. Plant Systematics and Evolution, v.194, p. 123-132, 1995.

BLUMENSCHEIN, A. Número de cromossomas de algumas espécies de orquídea. Publicação Científica da Universidade de São Paulo, Instituto de Genética, v.1, p. 45-50, 1960. 
BRIEGER, F. G.; LÜCKEL, E. Der Miltonia - Komplex - Eine Neubeurteilung 1. Einleitung und Schlüssel der Gattungen. Die Orchidee, v. 34, n.4, p. 128-134, (1983).

BRIEGER, F. G., VENCOVSKY, R. \& PARKER, I. U. Distâncias filogenéticas no gênero Cattleya. Ciência e Cultura, v.15, n.3, p. 187-188, 1963.

BROWN JR., K. S. Soils and vegetation. In: WHITMORE, T. C.; PRANCE, G.T. (Ed.). Blogeography and quaternary hlstory in tropical America. Cambridge: Oxford Clarendon Press, 1987a. cap.2, p. 19-45.

BROWN JR., K. S. Biogeography and evolution of neotropical butterflies. In: WHITMORE, T. C.; PRANCE, G.T. (Ed.). Blogeography and quaternary hlstory in tropical America. Cambridge: Oxford Clarendon Press, 1987b. cap.4, p. 66-104.

CHARANASRI, U.; KAMEMOTO, $H$. Additional chromosome numbers in Oncidium and allied genera. American Orchid Society Bulletin, v.44, p. 686-691, 1975.

CHARANASRI, U.; KAMEMOTO H.; TAKESHITA, M. chromosome numbers in Oncidium and allied genera. American Orchid Society Bulletin, v.42, p. 518-524, 1973.

CHASE, M. W. A reappraisal of the oncidioid orchids. Systematic Botany, v.11, p. 477-491, 1986.

CHASE, M. W.; PALMER, J. D. Floral morphology and chromossome number in subtribe Oncidinae (Orchidaceae): evolutionary insights from a philogenetic analysis of chloroplast DNA restriction site 
variation. In: SOLTIS, D. E.; DOYLE, J. J. (ED.). Molecular systematics in plants. London: Chapman and Hall, 1992. cap.14, p. 324-339.

CHATFIELD, C.; COLLINS, A. J. Introduction to multivariate analysis. Chapman \& Hall., 1980. 246p.

CONSELHO NACIONAL DE GEOGRAFIA Rio de Janeiro: IBGE, 1966. Folha $11-11$.

CUNHA FILHO, L. A. Contribuição ao estudo da evolução do subgênero Cyrtolaelia (Orchidaceae) com base na determinação das distâncias generalizadas de Mahalanobis. Piracicaba, 1966. 58p. Dissertação de Mestrado - Escola Superior de Agricultura "Luiz de Queiroz"/USP.

DRESSLER, R. L. The orchids: natural hystory and classification. Cambridge: Harvard University Press, 1990. 322p.

DRESSLER, R. L. Phylogeny and classification of the orchid family. Portland: Dioscorides Press, 1993.314p.

DRESSLER, R. L.; WILLIAMS, N. H. An overlooked genus in the Oncidiinae. American Orchid Society Bulletin, v.39, n.1 1, p. 988-994, 1970.

DUFRÊNE, M., GATHOYE, J.-L.; TYTECA, D. Biostatistical studies on western european Dactylorhiza (Orchidaceae) - D. maculata group. Plant Systematicas and Evolutlon, v.175, p. 55-72, 1991.

DUNCAN, T.; BAUM, B. R. Numerical phenetics: its uses in botanical systematics. Annual Review of Ecol. Systematics, v.12, p. 387-404, 1981. 
DUPUY, D. J.; FORD-LLOYD, B. V.; CRIBB, P. J. A numerical taxonomic analysis of Cymbidium, section Iridorchids (Orchidaceae). Kew Bulletin, v.40, n.2, p. 421,-434, 1985.

DUNSTERVILLE, G. C. K. Introduction to the world of orchids. New York: Doubleday \& Company, 1964. 102p.

DUNSTERVILLE, G. C. K.; GARAY, L. A. Venezuelan orchis illustrated. 1976. v. 6, p. 276-278.

FERRARI, M. R.; HUNZIKER, J. H. Taxonomia numerica exomorfologica de cuatro especies sudamericanas de Elytrigia (Gramineae). Darwiniana, v.27, n.1-4, p. 389-398, 1986.

GRANT, V. The origin of adaptations. New York: Columbia University Press, 1963. 606p.

HAFFER, J. Quaternary history of tropical America. In: WHITMORE, T. C.; PRANCE, G.T. (Ed.). Biogeography and quaternary history in tropical America. Cambridge: Oxford Clarendon Press, 1987a. cap.1, p. 1-18.

HAFFER, J. Biogeography of neotropical birds. In: WHITMORE, T. C.; PRANCE, G.T. (Ed.). Biogeography and quaternary history in tropical America. Cambridge: Oxford Clarendon Press, 1987b. cap.5, p. 105150.

HOEHNE, F. C. Álbum de orchidáceas brasileiras e o orchidário do Estado de São Paulo. São Paulo, 1930. 264p.

HOEHNE, F. C. Iconografia de orchidaceas do Brasil. 1949. 601 p. 
ILLG, R. D. Aspectos evolutivos em algumas Maxilarias brasileiras (Orchidaceae). Campinas, 1975. 58p. Tese de Doutorado Universidade Estadual de Campinas.

JAMES, F. C.; MCCULLOCH, C. E. Multivariate analysis in ecology and systematics: panacea or Pandora's box? Annual Review of Ecol. Systematics, v. 21, p.129-166, 1990.

LINDLEY, J. Miltónia spectabilis: Showy Miltonia. Edward's Botanical Register, v.23, p. 1992-1993, 1837.

MANLY, B. F. J. Multlvariate statistlcal methods: a primer. 2. ed. Chapman \& Hall, 1995. 215 p.

MARK, A.; NIR, M. D. The surviviors: orchid on a Puerto Rican. American Orchid Society Bulletin, v.57, n.9, p. 989-995, 1988.

MARTINS, P. S. Análise de clines e revisão taxonômica da espécie Miltonia spectabilis Ldl. (Orchidaceae - Oncidieae). Piracicaba, 1967. 39p. Dissertação de Mestrado - Escola Superior de Agricultura "Luiz de Queiroz"/USP.

MARTINS, P.S. Estudo da variação intra-específica no gênero Miltonia Ldl. (Orchidaceae-Oncidiae). Piracicaba, 1970. 68p. Tese de Doutorado - Escola Superior de Agricultura "Luiz de Queiroz"/USP,

MCQUEEN, J.; MCQUEEN, B. Orchids from Brazil. Melbourne: The Text Publishing Company, 1993. 200p.

MICROCAL SOFTWARE INC. Microcal origin. Versão 3.54, (software). 1994. 
MICROSOFT CORPORATION. Excel para windows 95. Version 7, (software). 1995.

MORRISON, D. F. Multivariate statistical methods. 2. ed. MCGraw-Hill Book Company, 1976. 415p.

PABST, G. F. J.; DUNGS, F. Orchidaceae brasiliensis. Heldeshein: BrückeVelag Kurt Schmersow, 1977. v.2., p. 196-197.

PEARSON, K. On the coefficient of racial likeness. Biometrika, v.18, p. $105-117,1926$.

PRANCE, G. T. Biogeography of neotropical plants. In: WHITMORE, T. C.; PRANCE, G.T. (Ed.). Blogeography and quaternary history in tropical America. Cambridge: Oxford Clarendon Press, 1987. cap.3, p. 46-65.

RAO, C. R. Advanced statistical methods in biometic research. New York: John Wiley \& Sons, 1952. 390 p.

RESENDE, R. M. S. Aplicação de técnicas de análise multivariada e eletroforese de isoenzimas em estudos de relações fenéticas no gênero Laelia seção Parviflora. Piracicaba, 1991. 130p. Dissertação de Mestrado - Escola Superior de Agricultura "Luiz de Queiroz"/USP.

ROHLF, F. J. Morphometrics. Annual Review Ecol. Systatics, v.21, p. 299$316,1990$.

SMALL, E.; FAWZI, M. Morphogeographic variation in Medicago monantha complex. Canadian Journal of Botany, v.70, p. 1292-1302, 1992. 
SINOTO, Y. Chromossome numbers in Oncidium alliance. Cyłologia, v.27, p. 306-313, 1962.

SINOTO, Y. Chromossomes numbers in Oncidium allied genera, I. Genus Oncidium. La Kromosomo, v.76, p. 2459-2473, 1969.

SNEATH, P. H. Thirty years of numerical taxonomy. Systematic Biology, v.44, n.3, p. 281-298, 1995.

SNEATH, P. H.; SOKAL, R. R. Numerical taxonomy: the principles and practice of numerical classification. San Francisco: W.H. Freeman and Company, 1973. 573p.

SOKAL, R. R.; SNEATH, P. H. Principies of numerical taxonomy. San Francisco: W.H. Freeman and Company, 1963.

STATSOFT INC. STATISTICA for Windows. Release 4.3 (software). 1993

SAS INSTITUTE INC. Statistical analysis system. Release 6.08, (software). Cary, 1992.

SAS INSTITUTE INC. SAS/STAT user's guide. Cary, 1994a. v.l: ACECLUS FREQ.

SAS INSTITUTE INC. SAS/STAT user's guide. Cary, 1994b. v.2: GLM VARCOMP.

SAS INSTITUTE INC. Multivariate statistical methods: practical applications. course notes. Cary, 1995. 471p.

SYSTAT INC. SYSTAT for Windows. Version 5.01, (software). Evanston, 1992. 
SWEET, H.R. The Miltonia complex in horticulture. American Orchid Society Bulletin, v.47, n.10, p. 917-925, 1978.

TYTECA, D.; DUFRÊNE, M. On the use of taxonomic study of critical plant group - case studies of western european orchidaceae. Annals of Botany, v.71, p. 257-277, 1993.

VAN DEN BERG, C. Estudo dos padrões de variabilidade intra e interespecífica em espécies brasileiras de Cattleya Lindley (Orchidaceae-Laeliinae). Campinas, 1996. 154p. Dissertação de Mestrado - Universidade Estadual de Campinas.

VENCOVSKY, R. Aplicação de alguns métodos estatísticos à sistemática. Piracicaba, 1960. 61p. Tese de Doutorado - Escola Superior de Agricultura "Luiz de Queiroz"/USP. 


\section{APÊNDICE 1}


Correlaçōes entre cada par de caracteres e seus niveis de significância entre espécies de Miltonia Ldl. Orchidaceae.

\begin{tabular}{|c|c|c|c|c|c|c|c|c|}
\hline Voriáveis & CSD & LSD & $\overline{C S L}$ & $\overline{L S L}$ & CPET & LPET & CPED & $C L A B$ \\
\hline$\overline{C S D}$ & 1.0000 & - & - & - & - & - & - & - \\
\hline LSD & $0.2389 *$ & 1.0000 & - & - & - & - & - & - \\
\hline CSL & $0.9712^{* * * \bullet}$ & $0.2635^{* \bullet e}$ & 1.0000 & - & - & - & - & - \\
\hline LSL & $0.2627^{\circ \cdot 0 \cdot 0}$ & $0.9561^{* * * *}$ & $0.2913^{\circ 00}$ & 1.0000 & - & - & - & - \\
\hline CPET & $0.9066^{* * *}$ & $0.5197^{* * *}$ & $0.9137^{* * * *}$ & $0.5463^{\circ * 0}$ & 1.0000 & - & - & - \\
\hline LPET & $0.1865^{* * * *}$ & $0.9186^{* * *}$ & 0.2100 & $0.9121^{\infty \cdots 0}$ & $0.4535^{\circ \cdots}$ & 1.0000 & - & - \\
\hline CPED & $0.4333^{\circ-0}$ & $0.7629^{\circ \cdots \bullet}$ & $0.4628^{\circ \cdots}$ & $0.7794^{\circ * \bullet}$ & $0.6361^{\infty \cdots 0}$ & $0.7767^{\circ \cdots 0}$ & 1.0000 & - \\
\hline CLAB & $0.5505^{* * *}$ & $0.8134^{\circ \cdots *}$ & $0.5786^{* * *}$ & $0.8412^{* * 0}$ & $0.7885^{* * *}$ & $0.7650^{\circ * 0}$ & $0.8371^{* * *}$ & 1.0000 \\
\hline LLAB & $0.2141^{\infty \cdots 0}$ & $08809^{\circ}$ & $0.2439^{\bullet \cdots \bullet}$ & $0.9026^{\circ \cdots *}$ & $0.5085^{\circ * *}$ & $0.8776^{\circ * 0}$ & $0.7491^{\infty \cdots}$ & $0.8467^{\circ \cdot 0 \cdot 0}$ \\
\hline cov & $0.3697^{\circ \cdots 0}$ & $0.6601^{\circ \cdots 0}$ & $0.3945^{\circ \cdots \bullet}$ & $0.6709^{\circ \cdots \bullet}$ & $0.5610^{\circ * 0}$ & $0.6609^{\circ \cdots}$ & $0.8859^{\circ \cdots \bullet}$ & $0.7719^{\circ \cdots \bullet}$ \\
\hline $\mathrm{CCOL}$ & $-.3437^{\circ \cdot \bullet}$ & $0.1932^{* * *}$ & $-.3622 * *$ & $0.1758^{* * *}$ & $-.1621^{* * *}$ & 0.0589 ns & $-.1466^{\circ *}$ & $0.0760 \mathrm{~ns}$ \\
\hline $\mathrm{LCOL}$ & $0.1861^{* * *}$ & $0.6526^{* 0 *}$ & $0.1928^{* * *}$ & $0.6671^{* * *}$ & $0.4023^{* * *}$ & $0.5507^{* *}$ & $0.5566^{* * *}$ & $0.6310^{\circ \infty}$ \\
\hline ECOL & $0.1667^{* \bullet}$ & $0.5965^{* * *}$ & $0.1947 * * *$ & $0.6116^{* 0 *}$ & $0.3907^{* * * *}$ & $0.5019^{\circ * 0}$ & $0.5295^{\circ \cdots}$ & $0.5535^{\circ 0 *}$ \\
\hline$\angle A B 20$ & $0.0491^{\mathrm{ns}}$ & $0.8379^{\circ \cdots 0}$ & $0.0794^{\mathrm{ns}}$ & $0.8643^{\circ 00}$ & $0.3653^{* 4 *}$ & $0.8416^{\circ 00}$ & $0.6562^{\circ 00}$ & $0.7568^{\circ * 0}$ \\
\hline LAB40 & $0.2233^{* * *}$ & 0.8779 & $0.2521^{* * *}$ & $0.9030=$ & $0.5174^{* \infty}$ & $0.8773^{\circ-\infty}$ & 0.7578 & $0.8508^{\circ * 0}$ \\
\hline$\angle A B 60$ & $0.2147^{\circ \cdots \bullet}$ & $0.8474^{\circ \cdots \bullet}$ & $0.2457^{* * \bullet}$ & $0.8625^{\circ 00}$ & $0.4727^{\circ \cdots \bullet}$ & $0.8902 * * 0$ & 0.7679 & $0.7913^{\circ .0}$ \\
\hline$\angle A B 80$ & $0.3469^{\circ * 0}$ & $0.6510^{0.0}$ & $0.3821^{\infty \cdots}$ & 0.6334 & 0.4829 & $0.7478^{\circ * 0}$ & $0.7945^{\circ * \bullet}$ & $0.6357^{*+4}$ \\
\hline SD2O & $0.2465^{* * *}$ & 0.8212 & $0.2753^{* 0 \bullet}$ & $0.8078^{\circ \cdots 0}$ & $0.5013^{* * *}$ & $0.7723^{\circ * \bullet}$ & $0.7681^{\infty \cdots}$ & $0.7747^{\circ \cdots \bullet}$ \\
\hline SD 40 & $0.2964^{\circ 0 *}$ & $0.9374^{\circ \cdots \bullet}$ & $0.3236^{* * *}$ & $0.9187^{\circ \cdots \bullet}$ & $0.5583^{\circ * 0}$ & $0.8866^{\circ-0.0}$ & $0.8223^{\circ * 0}$ & $0.8407^{\cdots \cdots}$ \\
\hline SD 60 & $0.2556^{* \pm *}$ & $0.9516^{\circ 00}$ & $0.2833^{* * \bullet}$ & $0.9215^{* *}$ & $0.5179^{* * * *}$ & $0.8996^{\circ \cdots}$ & $0.7278^{\circ \cdots \bullet}$ & $0.7974^{* \infty}$ \\
\hline SD80 & 0.2129 & $0.8805^{* * * *}$ & 0.2481 & $0.8411^{\infty \cdots}$ & $0.4536^{* * *}$ & $0.8633^{* * * *}$ & $0.7268^{\circ * \bullet}$ & 0.7381 \\
\hline SL2O & $0.3714^{\circ \cdots 0}$ & $0.7952^{* * *}$ & $0.4003^{* * *}$ & 0.8226 & $0.5967^{* * *}$ & $0.7683^{\circ \cdots}$ & $0.8081^{\infty \cdots 0}$ & $0.8127^{\circ \cdots \bullet}$ \\
\hline SL40 & $0.3550^{\circ \cdots \bullet}$ & $0.9165^{* * *}$ & $0.3815^{\circ \cdots \bullet}$ & $0.9465^{\circ}$ & $0.6121^{\infty \cdots \infty}$ & $0.8807^{* \cdots *}$ & $0.8353^{\circ \cdots \bullet}$ & $0.8732^{\circ \cdots}$ \\
\hline SL6O & $0.2141^{\cdots \infty}$ & $0.9341^{* * *}$ & $0.2404^{* \pm *}$ & $0.9530^{\circ * 0}$ & $0.4898^{\circ * * *}$ & $0.8951^{\circ \cdots \bullet}$ & $0.7109^{\circ \cdots \bullet}$ & $0.7973^{* * \bullet}$ \\
\hline SL8O & $0.2075^{\circ 0 \bullet}$ & $0.8841^{+\infty}$ & $0.2304^{* * *}$ & $0.8786^{\circ \cdots 0}$ & $0.4616^{\circ .0}$ & $0.8555^{\circ * * *}$ & $0.7144^{\circ * 0}$ & $0.7416^{\circ * * *}$ \\
\hline PET2O & $0.0858^{n s}$ & 0.8660 & $0.1079^{*}$ & $0.8465^{\circ \cdots \bullet}$ & $0.3596^{\circ 00}$ & $0.9139^{* \cdots}$ & $0.7455^{\circ \bullet \bullet}$ & $0.6851^{\circ \cdots 0}$ \\
\hline PET40 & $0.2015^{\circ 00}$ & $0.9157^{* * *}$ & $0.2252^{* * *}$ & $0.9162^{\circ * 0}$ & $0.4709^{* * * *}$ & $0.9688^{\circ * \bullet}$ & $0.8093^{\circ * 0}$ & 07902 \\
\hline PET60 & $0.1725^{* *}$ & 0.9099 & $0.2005^{\circ \cdots}$ & $0.8959 *$ & $0.4349^{\circ \cdots \bullet}$ & $0.9696^{\circ 00}$ & $0.7788^{\circ \cdots \bullet}$ & $0.7520 * * *$ \\
\hline PETBO & $0.3147^{\circ \cdot 0 \cdot 0}$ & $0.8342^{* * \bullet}$ & $0.3374^{* * *}$ & $0.8186^{* * * *}$ & $0.5163^{* * *}$ & $0.8980^{\circ \cdots \bullet}$ & $0.8322^{* * *}$ & $0.7453^{* \star \bullet}$ \\
\hline LAB25 & $0.4084^{\circ * *}$ & $0.7710^{\circ * 0}$ & $0.4567^{\circ \cdots \bullet}$ & $0.7870^{\circ \infty}$ & $0.6409^{\circ \cdots \bullet}$ & $0.7925^{* * *}$ & $0.8514^{\circ * \bullet}$ & $0.8803^{\circ * \bullet}$ \\
\hline LAB50 & $0.5820^{* * * *}$ & $0.7791^{\circ \infty}$ & $0.6139 * *$ & $0.8081^{\circ \cdots}$ & $0.8017^{* * *}$ & $0.7257^{\circ \cdots}$ & $0.8286^{\circ \cdots \bullet}$ & $0.9825^{\circ * 0}$ \\
\hline LAB75 & $0.4324^{* * \bullet}$ & $0.7704^{* \star *}$ & $0.4780^{* * *}$ & $0.7780 * 0 *$ & $0.6563^{\circ \cdots}$ & $0.7929^{\circ \cdots \bullet}$ & $0.8648^{\circ \cdots \bullet}$ & $0.8832^{* * *}$ \\
\hline
\end{tabular}

Os níveis de significância estão representados por ns - não significativo; * - significativo a $5 \% ;^{* *}$ - significativo a $1 \% ;^{* * *}$ - significativo a $0,1 \%$. 
Continuação:

\begin{tabular}{|c|c|c|c|c|c|c|c|c|}
\hline Varióveis & $\angle L A B$ & $\mathrm{cov}$ & $\mathrm{CCOL}$ & $\mathrm{LCOL}$ & $\mathrm{ECOL}$ & $\angle A B 20$ & LAB40 & $\angle A B 60$ \\
\hline CSD & - & - & - & - & 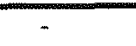 & - & - & 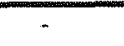 \\
\hline LSD & - & - & - & - & - & - & - & - \\
\hline CSL & - & + & - & - & - & - & - & - \\
\hline LSL & - & - & * & - & - & - & $=$ & - \\
\hline CPET & - & - & - & - & - & - & - & - \\
\hline LPET & ${ }^{-}$ & - & - & - & - & - & - & - \\
\hline CPED & - & - & - & . & - & - & - & - \\
\hline CLAB & - & - & - & - & - & - & - & - \\
\hline ULAB & 1.0000 & - & * & - & - & $\cdot$ & - & - \\
\hline cov & 0.6382 & 1.0000 & - & - & - & - & - & - \\
\hline $\mathrm{CCOL}$ & 02108 & $-.0766^{\mathrm{ns}}$ & 1.0000 & - & - & - & - & - \\
\hline LCOL & $0.5943^{\circ *}$ & $0.5611^{* 0 *}$ & 0.3898 & 1.0000 & - & - & - & - \\
\hline ECOL & $0.5443^{* \cdots}$ & $0.4930^{+* 0}$ & $0.1964^{* * *}$ & $0.7484^{* * *}$ & 1.0000 & - & - & - \\
\hline LAB20 & $0.9605^{\circ-0}$ & $0.5457^{* \ldots}$ & 0.3353 & $0.5682^{*}$ & $0.5044^{\cdots \cdots}$ & 1.0000 & - & - \\
\hline LAB4O & 0.9936 & 0.6501 & $0.2001^{* * * *}$ & $0.5955^{\circ}$ & $0.5465^{\circ-0}$ & 0.9569 & 1.0000 & - \\
\hline LAB60 & $0.9444^{* * *}$ & $0.6393^{* \cdots *}$ & $0.0253^{\text {ns }}$ & 0.4832 & $0.4523^{\circ * 0}$ & $0.8850^{2}$ & $0.9477^{* \cdots}$ & 1.0000 \\
\hline LAB8O & $0.6515^{\circ}$ & $0.6913^{\circ * 0}$ & $-.3568^{\circ * 00}$ & $0.2894^{\circ}$ & $0.3111+\infty$ & 0.5339 & $0.6628^{*}$ & $0.7551 * * 0$ \\
\hline SD2O & 0.7042 & $0.7991 * * 0$ & $0.0232^{\mathrm{ns}}$ & $0.6034^{* * \bullet}$ & $0.6013^{\circ 00}$ & $0.6472^{+4 *}$ & 0.7092 & $0.6722^{\circ * 0}$ \\
\hline SD 40 & $0.8251^{\infty}$ & $0.7753^{* * *}$ & $0.0555^{\text {ns }}$ & 0.6312 & 0.6136 & $0.7604^{* 0 *}$ & 0.8256 & OBO40"0 \\
\hline SD 60 & $0.8751^{\ldots+}$ & $0.6027^{*}$ & $0.1948^{\circ}$ & $0.5984^{\circ \cdots}$ & $0.5116^{\circ 00}$ & $0.8395^{\circ}$ & $0.8710 *$ & $0.8569 *$ \\
\hline SD80 & 0.8024 & 0.6360 & $0.1017^{n s}$ & $0.5161^{* * *}$ & $0.4524^{* \cdots}$ & $0.7612^{* * *}$ & $0.8021^{* * *}$ & $0.8117^{* 0 *}$ \\
\hline SL2O & 0.7024 & $0.8178^{\circ}$ & $-.0627^{n s}$ & 0.6099 & $0.5914^{*}$ & $0.6312^{*}$ & $0.7110^{\circ * 0}$ & 0.6794 \\
\hline SL40 & $0.8513^{\circ+0}$ & $0.7737^{* * 4}$ & $0.0357^{\mathrm{ns}}$ & $0.6580^{-0}$ & 0.6228 & $0.7844^{* * *}$ & $0.8547^{\circ \cdot 0}$ & $0.8251^{\infty}$ \\
\hline$S L 60$ & 0.9076 & $0.5845^{\circ .0 *}$ & $0.2270^{* a *}$ & $0.6102^{*}$ & $0.5455^{\infty}$ & 0.8822 & $0.9065^{* * *}$ & $0.8733^{*}$ \\
\hline SLBO & $0.8385^{\circ+*}$ & $0.6177^{+0 * *}$ & $0.1582^{* *}$ & $0.5580^{\circ+\infty}$ & $0.5148^{* 0}$ & $0.8056^{* * \bullet}$ & 0.8388 & $0.8203^{*-6}$ \\
\hline PET20 & 0.7942 & $0.6741^{\cdots}$ & $0.0568 \mathrm{~ns}$ & $0.5389^{* * *}$ & $0.5375^{\circ}$ & 0.7691 & 0.7989 & $0.8036 * * *$ \\
\hline PET 40 & $0.8851^{\cdots}$ & $0.7105^{* * *}$ & $0.0298 \mathrm{~ns}$ & $0.5704^{* * *}$ & 0.5336 & $0.8429 * * *$ & $0.8864^{* 0 .}$ & $0.8938^{*}$ \\
\hline PET60 & $0.8683^{* 0 *}$ & $0.6522^{*+4}$ & $0.0409^{n s}$ & $0.5249^{* * *}$ & $0.4802^{\infty}$ & $0.8295^{\circ \cdots}$ & $0.8679 \cdots$ & $0.8969+\cdots$ \\
\hline PET8O & $0.7498^{\circ+*}$ & $0.7278^{\circ * 0}$ & $-.1734^{+\infty *}$ & $0.4819^{\circ \cdots *}$ & $0.4648^{\circ}$ & $0.6774^{* \cdots}$ & $0.7539 \cdots$ & $0.8097^{* * 0}$ \\
\hline$\angle A B 25$ & $0.7703 \approx$ & $0.7972^{* * *}$ & $-.0519 \mathrm{~ns}$ & $0.5107^{* * *}$ & $0.4548^{*}$ & $0.7034^{\circ *}$ & $0.7807^{* 0}$ & $0.7744^{\infty \cdots *}$ \\
\hline LABSO & $0.8051^{\circ .00}$ & 0.7820 & $0.0429 \mathrm{~ns}$ & $0.6275^{\circ}$ & $0.5430^{\circ}$ & $0.7101^{*}$ & $0.8117^{*}$ & $0.7513^{\infty}$ \\
\hline LAB75 & $0.7609^{\circ \cdots 0}$ & $0.8213^{*}$ & $-.0772^{\text {ns }}$ & $0.5151^{\infty}$ & $0.4550^{\circ=000}$ & $0.6862^{* * *}$ & $0.7697^{* * *}$ & $0.7661 \ldots$ \\
\hline
\end{tabular}

Os níveis de significância estāo representados por ns - nāo significativo; ${ }^{*}$ - significativo a $5 \% ;^{* *}$ - significativo a $1 \% ;{ }^{* * *}$ - significativo a $0,1 \%$. 
Continuaçāo:

\begin{tabular}{|c|c|c|c|c|c|c|c|c|}
\hline Variáveis & LAB80 & SD20 & SD40 & SD60 & SD80 & SL2O & SL40 & SL60 \\
\hline CSD & - & - & - & - & 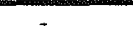 & - & - & - \\
\hline LSD & - & - & - & - & - & - & . & - \\
\hline CSL & - & - & - & - & - & - & - & - \\
\hline LSL & - & - & - & . & - & - & . & - \\
\hline CPET & - & - & - & - & - & - & - & - \\
\hline LPET & - & - & - & - & - & - & . & - \\
\hline CPED & - & - & - & - & - & - & - & - \\
\hline CLAB & - & - & - & - & - & - & - & - \\
\hline LLAB & - & - & - & - & - & - & - & - \\
\hline $\operatorname{cov}$ & - & - & - & - & - & - & - & - \\
\hline $\mathrm{CCOL}$ & . & - & - & - & - & - & - & - \\
\hline LCOL & - & - & - & - & - & - & - & - \\
\hline ECOL & . & - & - & - & - & - & - & - \\
\hline LAB2O & - & - & - & - & - & - & - & - \\
\hline LAB40 & $=$ & - & - & - & - & - & - & - \\
\hline LAB60 & - & - & - & - & - & - & - & - \\
\hline LABBO & 1.0000 & - & - & - & - & - & - & - \\
\hline SD2O & $0.6206^{* * * *}$ & 1.0000 & - & - & - & - & - & - \\
\hline SD 40 & $0.6946^{* * *}$ & $0.9242^{-4 *}$ & 1.0000 & - & - & - & - & - \\
\hline SD60 & $0.6347^{* * *}$ & $0.7365^{\infty}$ & $0.8883^{* * *}$ & 1.0000 & - & . & - & - \\
\hline SD80 & $0.7155^{* * *}$ & 0.7100 & $0.8405^{* * *}$ & $0.9192^{* * *}$ & 1.0000 & - & - & - \\
\hline SL2O & $0.6483^{\circ \cdots *}$ & $0.9318^{\circ \cdots}$ & $0.9043^{\circ * *}$ & 0.7334 & $0.7188^{* * * *}$ & 1.0000 & - & - \\
\hline SL40 & $0.6873^{\circ *}$ & $0.8925^{\circ \cdots *}$ & $0.9523^{\circ \cdots *}$ & $0.8747^{* \cdots *}$ & $0.8205^{\circ * *}$ & $0.9323^{\circ *-4}$ & 1.0000 & - \\
\hline SL60 & $0.6068^{* * *}$ & $0.7282^{\infty}$ & $0.8658^{* * 0}$ & $0.9491^{* *}$ & $0.8765^{\circ * * *}$ & $0.7401 \cdots$ & $0.9012^{* * \bullet}$ & 1.0000 \\
\hline SL8O & $0.6733^{* * *}$ & $0.7238^{\circ * * *}$ & $0.8327^{* \cdots *}$ & $0.8944^{\circ * * *}$ & $0.8983^{* * * *}$ & $0.7288^{* * *}$ & $0.8470^{\circ * * *}$ & 0.9222 \\
\hline PET20 & $0.7158^{* * *}$ & $0.8400^{\circ}$ & $0.8769^{\circ \cdots *}$ & $0.8119^{\circ * *}$ & 0.7800 & $0.8071^{\circ . * *}$ & $0.8555^{\circ \cdots}$ & $0.8118^{\circ * * *}$ \\
\hline PET40 & $0.7559^{* * * *}$ & $0.8266^{\circ \cdots *}$ & $0.9163^{\circ * *}$ & $0.8923^{* * *}$ & $0.8468^{\circ \cdots}$ & 0.8289 & 0.9162 & $0.8916^{* * *}$ \\
\hline PET60 & $0.7657^{* * * *}$ & $0.7536^{\circ \cdots}$ & $0.8768^{\circ \cdots *}$ & $0.9131^{* * *}$ & $0.8842^{\cdots \cdots}$ & 0.7536 & $0.8681^{* 0 *}$ & $0.8984^{\circ \cdots *}$ \\
\hline PET80 & 0.8489 & $0.7831^{\cdots \cdots}$ & $0.8652^{* *}$ & $0.8220^{\circ * * *}$ & $0.8534^{* * * *}$ & $08030^{\circ}$ & $0.8505^{\circ * *}$ & $0.7863^{\circ}$ \\
\hline LAB25 & $0.7791^{\circ \cdots *}$ & $0.7747^{\bullet \cdots *}$ & $0.8167^{\circ * 0}$ & $0.7484^{\circ * 0}$ & $0.7717^{\infty}$ & $0.8117 * \ldots$ & 0.8358 & $0.7461^{* 40}$ \\
\hline$\angle A B 50$ & $0.6241^{*+*}$ & $0.7706^{\circ * * *}$ & $0.8229^{\circ}$ & $0.7660^{\circ e *}$ & $0.7151^{* \cdots *}$ & $0.8200^{\circ 40}$ & $0.8622^{* * \bullet}$ & $0.7644 \ldots$ \\
\hline LAB75 & $0.8023^{\circ \cdots}$ & 0.7886 & 0.8236 & $0.7488^{* \cdots *}$ & $0.7715^{\circ * *}$ & $0.8187^{\circ * *}$ & $0.8381^{\cdots}$ & 0.7340 \\
\hline
\end{tabular}

Os níveis de significância estāo representados por ns - nāo significativo; * - significativo a $5 \% ;^{* *}$ - significativo a $1 \% ;^{* * *}$ - significativo a $0,1 \%$. 
Continuação:

\begin{tabular}{|c|c|c|c|c|c|c|c|c|}
\hline Varáveis & SL.8O & PET20 & PET40 & PET60 & PET80 & LAB25 & $\angle A B 50$ & LAB75 \\
\hline CSD & - & - & - & - & - & - & - & - \\
\hline LSD & - & - & - & - & - & - & - & - \\
\hline CSL & - & - & - & - & - & - & - & - \\
\hline LSL & - & - & - & - & - & - & - & - \\
\hline CPET & - & - & - & - & - & - & - & - \\
\hline LPET & - & - & - & - & - & - & - & - \\
\hline CPED & - & - & - & - & - & - & - & - \\
\hline CLAB & - & - & - & - & - & - & - & - \\
\hline LLAB & - & - & - & - & - & - & - & - \\
\hline $\mathrm{cov}$ & - & - & - & - & - & - & - & - \\
\hline CCOL & - & - & - & - & - & - & - & - \\
\hline LCOL & - & - & - & - & - & - & - & - \\
\hline ECOL & - & - & - & - & - & - & - & - \\
\hline$\angle A B 20$ & - & - & - & - & - & - & - & - \\
\hline$\angle A B 40$ & - & - & - & - & - & - & - & - \\
\hline$\angle A B 60$ & - & - & - & - & - & - & - & - \\
\hline LABBO & - & - & - & - & - & - & - & $\cdot$ \\
\hline SD2O & - & - & - & - & - & - & - & - \\
\hline SD 40 & - & - & - & - & - & - & - & - \\
\hline SD60 & - & - & - & - & - & - & - & - \\
\hline SD8D & - & - & $=$ & - & - & - & - & - \\
\hline SL2O & - & $\cdot$ & - & - & - & - & - & - \\
\hline SL40 & - & - & - & - & - & - & - & - \\
\hline SL6O & - & - & - & - & - & - & - & - \\
\hline SL8O & 1.0000 & - & - & - & - & - & - & - \\
\hline PET20 & $0.7963^{* \cdots *}$ & 1.0000 & - & - & - & - & - & - \\
\hline PET40 & $0.8464^{* * * *}$ & $0.9405^{* * *}$ & 1.0000 & - & - & - & - & - \\
\hline PET60 & $0.8695^{\circ \cdots}$ & 0.9106 & $0.9623^{\cdots \cdots}$ & 1.0000 & - & - & - & - \\
\hline PET8O & $0.8140^{\circ \cdots}$ & 0.8496 & $0.9015^{\circ \cdots}$ & 0.9178 & 1.0000 & $\cdot$ & - & - \\
\hline LAB25 & $0.7535 \cdots$ & $0.7427 \cdots \cdots$ & $0.8115^{\circ * *}$ & $0.7923^{* * *}$ & $0.8318^{* * * *}$ & 1.0000 & - & - \\
\hline LAB5O & $0.7178^{* * *}$ & $0.6532^{* * *}$ & $0.7571 \ldots$ & $0.7177^{\circ \cdots *}$ & $0.7343^{\cdots *}$ & $0.8817^{* \cdots *}$ & 1.0000 & - \\
\hline LAB75 & $0.7497 \cdots \cdots$ & $0.7448^{\circ \cdots *}$ & $0.8110^{\circ * * *}$ & $0.7915^{\circ * * *}$ & $0.8457^{\cdots \cdots}$ & $0.9585 \cdots$ & $0.8874 \cdots$ & 1.0000 \\
\hline
\end{tabular}

Os níveis de significância estāo representados por ns - não significativo; ${ }^{*}$ - significativo a $5 \%$; $^{* *}$ - significativo a $1 \%$; ${ }^{* * *}$ - significativo a $0,1 \%$. 